Universidade de São Paulo

Escola Superior de Agricultura "Luiz de Queiroz"

Metabolismo do nitrogênio e concentração de nutrientes no cafeeiro irrigado em razão da dose de $\mathbf{N}$

Ana Paula Neto

Dissertação apresentada para obtenção do título de Mestre em Ciências. Área de concentração: Fitotecnia

\title{
Piracicaba
}

2009 


\title{
Ana Paula Neto
}

Engenheiro Agrônomo

\section{Metabolismo do nitrogênio e concentração de nutrientes no cafeeiro irrigado em razão da dose de $\mathbf{N}$}

\author{
Orientador: \\ Prof. Dr. JOSÉ LAÉRCIO FAVARIN
}

Dissertação apresentada para obtenção do título de Mestre em Ciências. Área de concentração: Fitotecnia

\section{Piracicaba}


Dados Internacionais de Catalogação na Publicação DIVISÃO DE BIBLIOTECA E DOCUMENTAÇÃO - ESALQ/USP

Neto, Ana Paula

Metabolismo do nitrogênio e concentração de nutrientes no cafeeiro irrigado em razão da dose de N / Ana Paula Neto. - - Piracicaba, 2009.

93 p. : il.

Dissertação (Mestrado) - - Escola Superior de Agricultura "Luiz de Queiroz", 2009.

Bibliografia.

1. Aminoácidos 2. Café 3. Fenologia 4. Macronutriente 5. Micronutriente 6. Redutase de nitrato I. Título

CDD 633.73

N469m

"Permitida a cópia total ou parcial deste documento, desde que citada a fonte - 0 autor" 
Aos meus pais José Aparecido Neto e Aparecida de Fátima Nascimento Neto, razão do meu existir, base e porto seguro na minha caminhada Às minhas irmãs Ana Maria e Juliana, eternas cúmplices do que eu sou

À minha sobrinha Lorena, vida nova a família

DEDICO 


\section{AGRADECIMENTOS}

À Deus, fonte de toda sabedoria, pela vida, por todo crescimento, por ser presença constante na minha caminhada, por todo amor com que cuida de cada detalhe da minha vida e por me proporcionar tantas experiências especiais.

Ao meu orientador Professor Dr. José Laércio Favarin pelos ensinamentos, amizade e acolhida durante todo esse tempo. Por todo aprendizado proporcionado nesse tempo de convivência, pelo entusiasmo em ensinar e por poder dividir contigo essa vitória.

Ao Conselho Nacional de Desenvolvimento Científico e Tecnológico (CNPq) pela concessão da bolsa de estudo, fundamental para o desenvolvimento desse trabalho.

À Fazenda Arakatu, por disponibilizar a área experimental, em especial ao Wesley Vieira Moreira, por todo auxílio em todas as fases de realização do experimento. Ao Harry pelo apoio e ao Antonio, Cássio e demais funcionários da Fazenda pelo fundamental apoio para a realização do trabalho.

Ao Professor Luiz Antônio Gallo, pela orientação nas análises e por ceder o laboratório para realização das mesmas.

Ao Dr Enio Tiago de Oliveira e todo o pessoal do CEBTEC pelo auxílio técnico na realização das análises laboratoriais.

Ao Professores Klaus Reichardt e Cássio Hamilton Abreu Junior pelas orientações.

À Cleusa Pereira Cabral pela amizade sincera e por todo auxílio técnico nas análises laboratoriais.

À Isabeli Pereira Bruno pelo auxílio em todas as etapas de realização do Projeto.

Ao André Rodrigues dos Reis pelo auxílio e orientações, mesmo a distância.

Ao Professor José Lavres Junior pelos auxílios nas análises estatísticas e por sempre me animar na realização deste trabalho. 
Ao Professor Ricardo Antunes de Azevedo, à Salete Aparecida Gaziola e todo pessoal do Laboratório de Genética pelo auxílio nos momentos de dúvidas e na realização de algumas análises laboratoriais.

As meninas do laboratório de Nutrição Mineral de Plantas: Nivanda Maria de Moura Ruiz, Edinéia Cristina Scervino Mondoni, Lúcia Helena Spessotto Pavan Forti, Lurdes Aparecida Dário Gonzalez e Sueli Maria Amaral Campos Bovi pela agradável convivência no laboratório e pelo auxílio na realização das análises nutricionais.

Ao Professor Francisco Antônio Monteiro por ceder as estruturas laboratoriais para a realização das análises minerais.

Ao Professor Hilton Thadeu Zarate do Couto pelas dicas estatísticas.

Ao Professor Carlos Tadeu dos Santos Dias por me auxiliar nas análises estatísticas deste trabalho.

Ao Professor Ladaslav Sodek pela disposição em ensinar.

Ao Professsor Paulo Mazzafera pelo apoio no projeto.

Ao Luiz Humberto Gomes (Beto), da Genética, à Denise de Lourdes Colombo Mescolotti e André, do Laboratório de Micorrizas, ao Rodrigo e Professora Marta, do Laboratório de Frutas e Hortaliças (LAN), à Fátima e Profesora Helaine Carrer pelo auxílio no preparo das amostras e empréstimos de equipamentos.

Aos funcionários Erreinaldo Donizeti Bortolazzo, Marcelo Valente Batista pelo auxílio nas áreas experimentais da ESALQ.

Ao Cláudio Luís Gonzaga (CENA) pela concessão de N líquido para transporte das amostras.

Ao Admir de Almeida Campos, pelo fornecimento de alguns reagentes e pelas dicas nas análises.

À bibliotecária Eliana Maria Garcia pelas correções na dissertação. 
Aos colegas da Sala 7: Rafael Tadeu de Assis, Tiago Tezotto, Rodrigo Estevam Munhoz de Almeida, Paula Rodrigues Salgado, Adriene Woods Pedrosa, Priscila de Oliveira, Carlos Francisco Ragassi e Halan Vieira, pelo agradável convivência durante esse tempo de trabalho. Pelos especiais momentos de descontração e de estudos vividos com vocês.

Ao amigo e companheiro de viagem Rodrigo Estevam Munhoz de Almeida (Txarli-Braun) pela companhia nas viagens e por todo aprendizado a mim proporcionado por esse Brasil afora. Pelas ajudas nas viagens e nas análises e pela experiência de vida, serei eternamente grata.

Aos demais companheiros de viagem: Tiago Tezotto (Sauipi), Artur Serafini Volpato (Laguiño), Rafael Tadeu de Assis, Samuel Ferreira Balieiro (Maguiliña), Gabriel Costa Junqueira (Cumpañero), Túlio Ticianeli (100-Anel), Bruno (Aznésio), Dario (Bilau) pela companhia nas viagens e pelo auxílio na realização das análises na Bahia.

Ao André Luís Garcia Alves (Lala) pela importante ajuda nas coletas, no preparo das amostras e nas análises laboratoriais.

À todos os professores e colegas da pós graduação, pelos ensinamentos partilhados.

Aos colegas do Prédio da Agricultura Celestino Alves Ferreira, Silvia Borghesi, Gustavo, Creusa e Léia pelo agradável convívio durante o período do mestrado.

Ao Pessoal do GEA e PACES, pela disponibilidade de ajudar e aprender. Pelas conversas e pela possibilidade de trocas de experiências. Pela ajuda na colheita do experimento.

Ao Tiago Barreto Garcez pela amizade, companhia e pelo auxilio nas análises laboratoriais.

À Luciane Aparecida Lopes Toledo por toda ajuda junto ao programa de pós-graduação.

Ao João Luis pelas dicas nos projetos de pesquisa relacionados.

À Universidade Federal de Viçosa por ser berço de conhecimento.

À Professora Hermínia Emílio Prieto Martinez, Bruno Galvêas Laviola, Junia Maria Clemente e Adriene Woods Pedrosa por me iniciarem nas pesquisas cafeeiras. 
Ao Darik, Flávio (Senta), Jonas (Kuzido), Claudinha, Giovani (Duma égua) pela hospedagem durante as viagens para a Bahia.

Ao Tiago Cavalheiro Barbosa pelo companheirismo e presença na minha vida.

Às meninas da republica: Kelly Justin da Silva, Adriene Woods Pedroza e Vanessa Silveira Duarte pela agradável convivência nesse período.

Ao GOU Água Viva, Renata, Lorena, Tathiana, Márcio, Carolina e todos que tornaram mais suave minha jornada nesse período.

À Patrícia Viegas e Mauro Sérgio Oliveira Leite pela amizade e presença.

À eterna República Malwee, Marina, Laila, Elaine, Maristela, Rafaela, Milena, Lorena, Cíntia, Patrícia e Luciana pela amizade.

Ao Povo da Capela e do GOU Imaculado Coração de Maria, porque mesmo a distância, permanecem presentes no coração.

Aos meus Familiares, Avós, Tios, Primos e Cunhado por serem meu berço e porto seguro, por me apoiarem e torcerem por meu sucesso. Em especial ao Tio João Donisete por sempre me apoiar nos estudos e pelo exemplo de vida e dedicação e à Tia Dezuita e Tio Pedro pelos ensinamentos de vida.

Às minhas irmãs Ana Maria e Juliana, que mesmo a distância permanecem "do lado de dentro", por todo amor, cuidado e companheirismo.

E por fim aqueles a quem devo a vida e tudo o que sou - meus pais José Aparecido Neto Aparecida de Fátima Nascimento Neto, que não pouparam esforços para que meu caminho fosse mais suave. Pelo amor, pelas orientações, pela presença, pela Vida! 
"Que Deus me permita falar como eu quisera, e ter pensamentos dignos dos dons que recebi, por que é Ele mesmo quem guia a sabedoria e emenda os sábios, porque nós estamos nas suas mãos, nós e nossos discursos, toda a nossa inteligência e nossa habilidade; foi ele quem me deu a verdadeira ciência de todas as coisas, quem me fez conhecer a constituição do mundo e as virtudes dos elementos, o começo, o fim e o meio dos tempos, a sucessão dos solstícios e as mutações das estações, os ciclos dos anos e as posições dos astros, a natureza dos animais e os instintos dos brutos, os poderes dos espíritos e os pensamentos dos homens, a variedade das plantas e as propriedades das raízes. Tudo o que está escondido e tudo que esta aparente eu conheço: porque foi a sabedoria criadora de todas as coisas, que mo ensinou."

Sab 7, 15-20 


\section{SUMÁRIO}

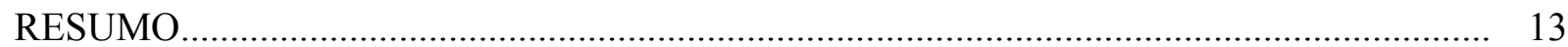

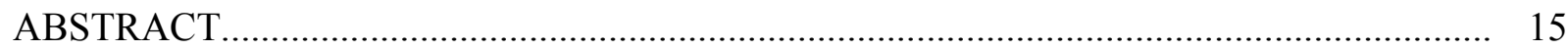

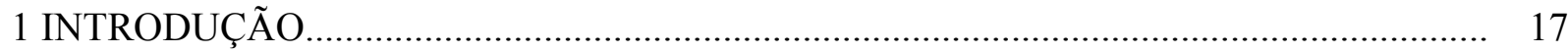

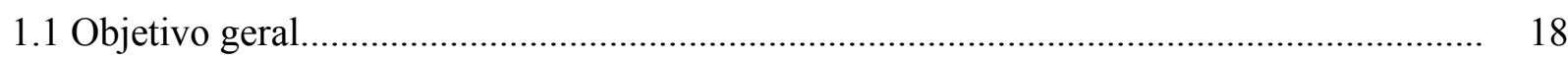

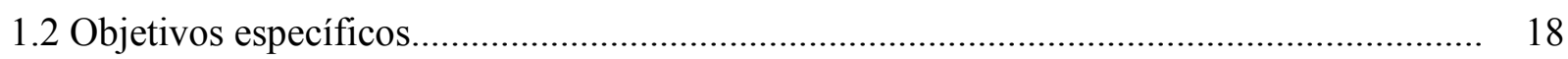

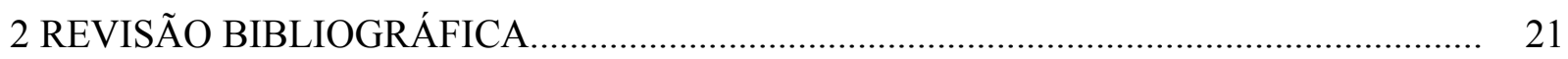

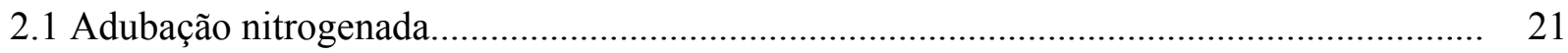

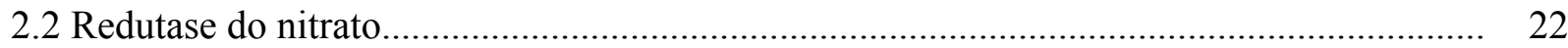

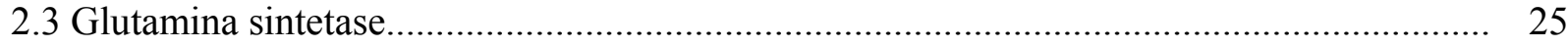

2.4 Urease

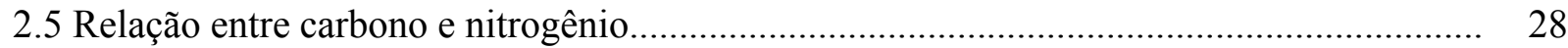

2.6 Fenologia e concentração foliar de nutrientes...................................................................... 30

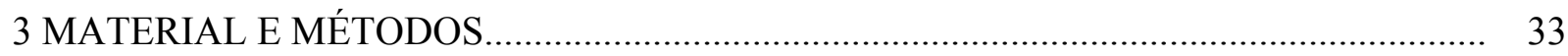

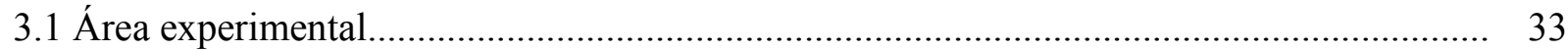

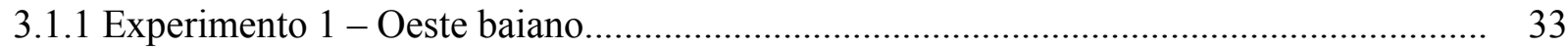

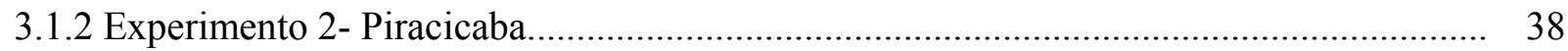

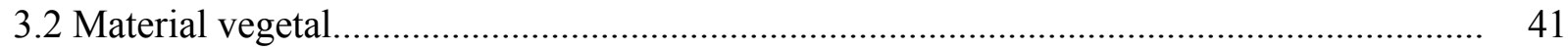

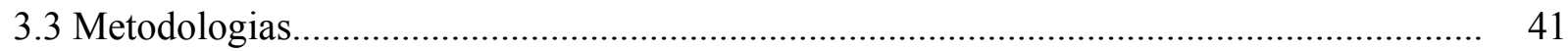

3.3.1 Extração e determinação da atividade da redutase do nitrato (RN; EC 1.6.6.1).............. 41

3.3.2 Determinação da atividade da urease (EC 3.5.1.5)..................................................... 43

3.3.3 Preparo dos extratos para análise de glutamina sintetase e proteína................................. 43

3.3.4 Determinação da atividade da glutamina sintetase (GS; EC 6.3.1.2) .............................. 44

3.3.5 Determinação da concentração de proteína total solúvel................................................. 44

3.3.6 Extração e quantificação de aminoácidos......................................................................... 45

3.3.7 Determinação da concentração de pigmentos................................................................... 45

3.3.7.1 Determinação da quantidade de clorofila $a$, clorofila $b$, clorofila total......................... 45

3.3.7.2 Determinação da quantidade de carotenóides................................................................ 46

3.3.8 Determinação das concentrações de N-total, N-nitrato e $\mathrm{N}$-amoniacal.............................. 46

3.3.9 Determinação das concentrações foliares dos demais nutrientes..................................... 47 


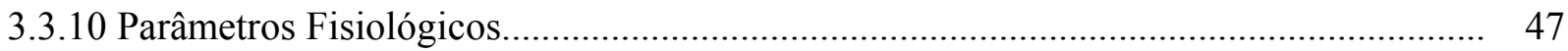

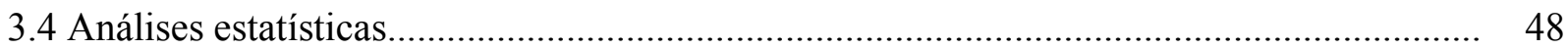

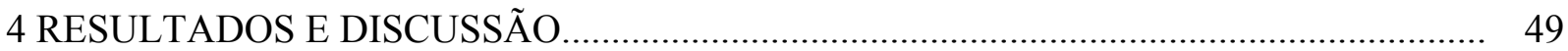

4.1 Características do solo e clima do Oeste baiano.................................................................... 49

4.2 Metabolismo do N - Oeste baiano................................................................... 51

4.3 Concentrações foliares de macro e micronutrientes - Oeste baiano.................................... 63

4.4 Características do solo e clima de Piracicaba...................................................................... 74

4.5 Metabolismo do N - Piracicaba.................................................................................... 74

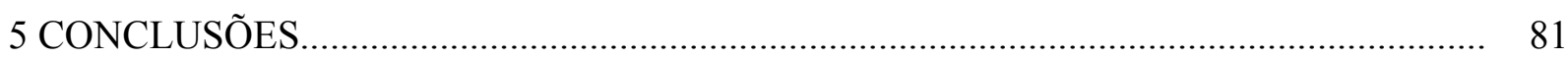

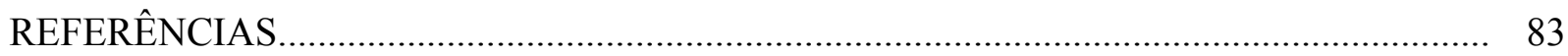




\section{RESUMO}

\section{Metabolismo do nitrogênio e concentração de nutrientes no cafeeiro irrigado em razão da dose de $\mathbf{N}$}

A adubação nitrogenada e sua implicação no metabolismo do cafeeiro ainda não são bem conhecidas nas condições de campo, em cafeicultura altamente tecnificada, com temperatura média de outono-inverno superior a $22{ }^{\circ} \mathrm{C}$ e maior quantidade de horas-luz. O objetivo da presente pesquisa foi avaliar a atividade das enzimas redutase do nitrato (RN), glutamina sintetase (GS) e urease em função da dose de nitrogênio (sem N, 200, 400, 600 e $800 \mathrm{~kg} \mathrm{ha}^{-1}$ ). Avaliou-se também a influência das doses de N (uréia) nas concentrações de N-total, nitrato, amônio, clorofila e carotenóides presentes nas folhas; as flutuações de macro e micronutrientes; bem como a correlação entre a produtividade e doses de N. Objetivou-se também identificar a época do pico da atividade da RN. Os experimentos foram realizados no Oeste baiano e em Piracicaba, SP. As avaliações foram realizadas nas fases fenológicas: vegetação, antese, fruto chumbinho, granação e maturação. A maior atividade da RN ocorreu com o fornecimento de 800 $\mathrm{kg} \mathrm{ha}^{-1}$ de $\mathrm{N}$, sem variação nas demais doses, bem como não influenciou a atividade da GS e urease. As concentrações de nitrato e amônio não aumentaram com as doses de $\mathrm{N}$, mas a concentração de aminoácidos foi crescente com a dose do nutriente. A maior atividade da RN verificou-se na fase de vegetação e granação dos frutos, a qual foi superior às 12:00 h, enquanto as atividades da GS e urease foram superiores na fase de granação dos frutos. A maior concentração de nitrato se deu entre a fase de fruto chumbinho e início da granação e do amônio no final da granação. O pico da atividade da $\mathrm{RN}$ aconteceu aos 25 dias após a adubação nitrogenada. O uso de altas doses de $\mathrm{N}$ não prejudicou a concentração de macro e micronutrientes foliar. Finalmente, a máxima produtividade do cafeeiro foi obtida com a aplicação de $400 \mathrm{~kg} \mathrm{ha}^{-1}$ de N.

Palavras-chave: Coffea arabica; redutase do nitrato; glutamina sintetase; macro e micronutrientes; aminoácidos; fenologia 


\section{ABSTRACT \\ Nitrogen metabolism and nutrient concentration in irrigated coffee plants due to nitrogen fertilization rates.}

The nitrogen fertilization and its implication in the nitrogen metabolism of coffee plants are not well known in high technology production under field conditions with autumn-winter average temperatures above $22^{\circ} \mathrm{C}$ and a larger photoperiod. The objective of this work was to evaluate the nitrate reductase, glutamine synthetase and urease activity due to nitrogen fertilization rates (without N, 200, 400, 600 e $800 \mathrm{~kg} \mathrm{ha}^{-1}$ ). In the present work was evaluated also the influence of nitrogen rates on total nitrogen, nitrate, ammonium, chlorophylls and carotenoids concentration in the leaves, the variation of macro and micronutrients as well as the correlationship between coffee yield and nitrogen fertilization rates. Moreover, the goal of this study was to identify the period of peak activity of nitrate reductase. The experiment was carried out at western of Bahia State and Piracicaba, State of Sao Paulo, Brazil. The periods of evaluations were plant growth, anthesis, pin head fruits, filling and maturation fruits stage development. The highest nitrate reductase activity occurred with $800 \mathrm{~kg} \mathrm{ha}^{-1} \mathrm{~N}$ supply and no changes on this enzyme were observed regarding other rates. Therefore, the nitrogen rates did not affect the glutamine synthetase and urease activity. The nitrate and ammonium concentration did not increase with nitrogen rates; however, the aminoacids concentration increased due to nitrogen fertilization rates. The highest activity of nitrate reductase was observed at 12:00h during plant growth and filling fruits stage development. On the other hand, the higher activity of glutamine synthetase and urease were during filling fruits stage. The highest nitrate concentration was detected during between pin head and beginning of filling fruits stage, and the highest ammonium concentration was during end of filling fruits stage development. The peak activity of nitrate reductase was 25 days after nitrogen fertilization. The high nitrogen rates did not affect the macro and micronutrients concentration in the leaves. The greater coffee yield was provided with $400 \mathrm{~kg}$ $\mathrm{ha}^{-1}$ of nitrogen supply.

Key words: Coffea arabica; nitrate reductase, glutamine synthetase, macro and micronutrients, aminoacids, phenology. 


\section{INTRODUÇÃO}

A cultura do café tem grande destaque no cenário agrícola nacional e, devido ao alto custo de produção nas regiões de montanha, seu cultivo avança para regiões não tradicionais, como o Oeste do Estado da Bahia. Esta região apresenta relêvo plano, facilmente mecanizável, o que propicia a utilização de alta tecnologia, como a irrigação por pivô-central. Os cafeeiros desta região apresentam elevadas taxas de crescimento vegetativo e índice de produtividade média de 50 sacas ha $^{-1}$ ano $^{-1}$. O elevado crescimento vegetativo e produtividade ocorrem, basicamente, pela maior quantidade de horas de luz devido à menor nebulosidade, e temperatura média por volta de $20^{\circ} \mathrm{C}$ nos meses de outono-inverno, superior às regiões cafeeiras tradicionais.

As discussões relacionadas ao metabolismo da planta são muitas vezes separadas das pesquisas que abordam a produtividade da cultura, devido à diferença de foco entre estes profissionais e a necessidade de se abordar aspectos específicos dos propósitos de investigação. Entretanto, a produtividade está relacionada à bioquímica e, portanto, os dois estão intimamente relacionados (LAWLOR; LEMAIRE; GASTAL, 2001)

$\mathrm{O}$ nitrogênio $(\mathrm{N})$ é o nutriente requerido em maior quantidade pelo cafeeiro. Este nutriente participa da síntese de proteínas estruturais e enzimáticas, as quais são responsáveis pela síntese de outras proteínas e dos intermediários metabólicos e componentes da estrutura celular, como carboidratos, lipídios e pigmentos. Estes compostos constituem a estrutura da planta e são requeridos para o crescimento celular e dos órgãos, como os frutos (LEMAIRE et al., 1992; LAWLOR, 1995). O entendimento do metabolismo do $\mathrm{N}$ nas principais fases fenológicas, poderá contribuir para a eficiência no uso deste nutriente.

Para ajustar a dose e época de aplicação do fertilizante à demanda da planta são realizados estudos de curva de resposta a doses de N, aplicados em diferentes fases. No entanto, estes estudos são prejudicados pela adição de $\mathrm{N}$ no sistema por meio das chuvas e também da própria reserva do solo, que podem afetar a resposta da planta a adubação nitrogenada. Da mesma forma, as perdas por lixiviação e as emissões gasosas tanto dos solos quanto das plantas comprometem as interpretações em relação a esse nutriente. Além disso, as respostas podem ser diferenciadas em razão das condições de cultivo, variedade, região, clima e ano agrícola. Portanto, para aumentar a eficiência no uso do $\mathrm{N}$ é necessário desenvolver e aprimorar modelos 
de simulação baseados nas relações empíricas, pela incorporação de informações bioquímicas (LAWLOR, 2002).

Nas condições específicas do cultivo no Oeste baiano não tem sido realizado com a freqüência necessária pesquisas básicas e, portanto, pouco se sabe sobre a eficiência pelo uso de dose elevada de nitrogênio, da ordem de $800 \mathrm{~kg} \mathrm{ha}^{-1}$, bem como sobre a sua influência no metabolismo do cafeeiro. O mérito da presente pesquisa se deve, em parte, as avaliações fisiológicas e bioquímicas realizadas em condições de campo, com plantas em produção. A maioria dos trabalhos na mesma linha de pesquisa são realizados com mudas, em condições de viveiro ou em laboratório e os resultados obtidos desta maneira não são aplicáveis aos cafeeiros cultivados em condições de campo.

Este trabalho foi realizado com base nas seguintes hipóteses: (i) a partir de determinada dose de nitrogênio, a assimilação do nutriente pelo cafeeiro pode ser limitada; (ii) os compostos nitrogenados e enzimas envolvidas no metabolismo do nitrogênio apresentam, possivelmente, comportamento diferenciado nas fases fenológicas da planta; (iii) o(s) pico(s) de atividade da enzima redutase do nitrato deve(m) ocorrer(em) nos primeiros dias após a adubação nitrogenada; e (iv) o uso de altas doses de nitrogênio pode afetar a concentração de outros nutrientes na folha.

\subsection{Objetivo geral}

Este trabalho foi realizado com o objetivo de entender o metabolismo do nitrogênio e as variações nas concentrações de nutrientes nas fases fenológicas de cafeeiro em produção, em sistema altamente tecnificado, com utilização de fertirrigação, em condições de campo.

\subsection{Objetivos específicos}

- Avaliar as atividades das enzimas redutase do nitrato, glutamina sintetase e urease, bem como quantificar aminoácidos em diferentes fases fenológicas e doses de nitrogênio.

- $\quad$ Determinar o(s) pico(s) de atividade da enzima redutase do nitrato após a aplicação do nitrogênio.

- Determinar as concentrações de N-total, nitrato, amônio, clorofila e carotenóides nas fases fenológicas do cafeeiro em diferentes doses de nitrogênio. 
- Verificar as flutuações nas concentrações de macro e micronutrientes presentes nas fases fenológicas do cafeeiro, em razão das doses de nitrogênio.

- $\quad$ Correlacionar a produtividade do cafeeiro com as doses de nitrogênio. 


\section{REVISÃO BIBLIOGRÁFICA}

\subsection{Adubação nitrogenada}

O cafeeiro é uma das culturas mais exigentes em nitrogênio $(\mathrm{N})$, cuja recomendação varia entre 150 e $450 \mathrm{~kg} \mathrm{ha}^{-1}$, de acordo com as condições da lavoura e expectativa de produção (RAIJ et al., 1996; RIBEIRO; GUIMARÃES; ALVAREZ, 1999). Um suprimento adequado de N promove rápido desenvolvimento da planta, especialmente pelo aumento do número de pares de folhas e ramos plagiotrópicos por planta, número de nós por ramos e flores por nós, relacionados diretamente com a produtividade do cafeeiro (MALAVOLTA, 1986; WILLSON, 1985; FAHL et al., 1994; NAZARENO et al., 2003). O nitrogênio é considerado, depois da deficiência hídrica, o principal fator que regula o crescimento das plantas, portanto, essencial à produtividade.

Embora o nitrogênio esteja presente em grande quantidade no solo, apenas uma fração de, aproximadamente, 2 a 3\% está disponível às plantas. Além disso, parte pode ser perdida por lixiviação, volatilização, desnitrificação e/ou exportação pela colheita dos frutos (PEOPLES; HERRIDGEE; LADHA, 1995). Dos aspectos que podem afetar o aproveitamento do N pelas plantas cabe mencionar a disponibilidade de água, $\mathrm{pH}$, fertilidade e tipo de solo, bem como a presença de alumínio e organismos do solo, entre outros fatores. A adubação com fontes nitrogenadas inorgânicas aumenta a disponibilidade de $\mathrm{N}$, entretanto pode incrementar as emissões de $\mathrm{N}_{2} \mathrm{O}$ e NO (MATSON; BILLOW; HALL, 1996; MATSON; NAYLOR; ORTIZMONASTERIO, 1998; WEITZ et al., 2001). Estas perdas são minimizadas pela sincronização da aplicação do fertilizante à demanda da planta, que tende a diminuir as emissões de óxidos de $\mathrm{N}$ e as perdas por lixiviação (MATSON; NAYLOR; ORTIZ-MONASTERIO, 1998; PANEK et al., 2000).

Várias fontes de $\mathrm{N}$ são utilizadas para suprir a necessidade do cafeeiro, entretanto a mais comum é a uréia, em razão do seu baixo custo. No entanto, sua utilização implica, quase sempre, em perdas por volatilização na forma de $\mathrm{N}$ amoniacal, cujo processo é intenso quando a uréia é aplicada na superfície, como se faz rotineiramente nas adubações dos cafezais.

A maioria das plantas absorve o $\mathrm{N}$, preferencialmente, na forma de nitrato $\left(\mathrm{NO}_{3}{ }^{-}\right)$, comumente disponível às plantas em solos com $\mathrm{pH}_{\mathrm{CaCl}_{2}}$ superior a 5,5. Qualquer forma química de $\mathrm{N}$ em solos com pH próximo da neutralidade é transformada em nitrato pela ação das bactérias nitrificadoras. Segundo Coelho et al. (1991) a absorção da forma amoniacal reduz o pH da 
rizosfera, devido à liberação de $\mathrm{H}^{+}$, fato que pode influenciar a disponibilidade e a absorção de alguns nutrientes, principalmente os micronutrientes (FENN; TAYLOR BURK, 1993).

O ciclo anual de reprodução do cafeeiro é constituído de 5 fases fenológicas: (i) florescimento ou antese, (ii) frutos chumbinho, (iii) frutos em expansão rápida, (iv) granação e (v) maturação (Figura 1). Nestas fases, há grande variação na absorção e na capacidade de assimilação do N pela planta (CARVAJAL; ACEVEDO; LOPEZ, 1969; TALEISNIK; BRICENO; CARVAJAL, 1980; CARELLI; FAHL; MAGALHÃES, 1989).

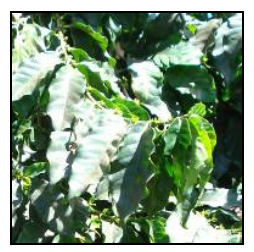

Vegetação

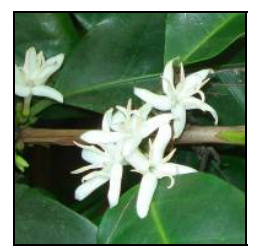

Florescimento

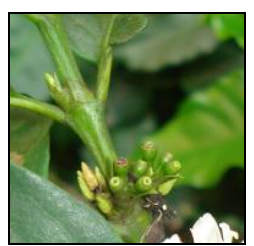

Chumbinho

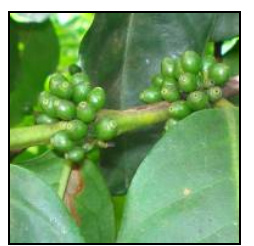

Expansão

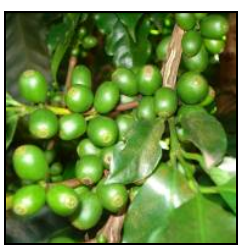

Granação

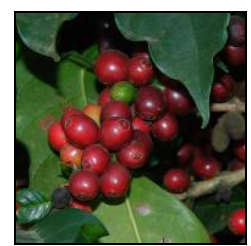

Maturação

Figura 1 - Fenologia do cafeeiro, fase vegetativa e da frutificação (florescimento, fruto chumbinho, expansão, granação e maturação)

\subsection{Redutase do nitrato}

$\mathrm{O}$ nitrato $\left(\mathrm{NO}_{3}{ }^{-}\right)$e o amônio $\left(\mathrm{NH}_{4}{ }^{+}\right)$são as principais formas de $\mathrm{N}$ inorgânico absorvido pelas raízes das plantas superiores. No entanto, para cumprir sua função nutricional o $\mathrm{NO}_{3}{ }^{-}$ precisa ser reduzido a $\mathrm{NH}_{4}{ }^{+}$e assimilado em compostos orgânicos. A assimilação do nitrato a amônio é mediada por duas enzimas: (i) a redutase do nitrato $(\mathrm{RN})$, que transforma nitrato em nitrito, processo que ocorre no citosol das células; e (ii) a redutase do nitrito (NiR) que transforma nitrito a amônio, nos plastídeos das células. Com a formação do amônio, o $\mathrm{N}$ é incorporado em aminoácidos (MARSCHNER, 1995).

$$
\begin{gathered}
\mathrm{NO}_{3}^{-}+8 \mathrm{H}^{+}+8 \mathrm{e}^{-} \rightarrow \mathrm{NH}_{3}+2 \mathrm{H}_{2} \mathrm{O}+\mathrm{OH}^{-} \\
\mathrm{NO}_{3} \rightarrow \mathrm{NO}_{2} \rightarrow \mathrm{NH}_{4} \rightarrow \text { aminoácidos } \rightarrow \text { proteínas } \\
\mathrm{NO}_{3}{ }^{-}+\mathrm{NAD}(\mathrm{P}) \mathrm{H}+\mathrm{H}^{+}+2 \mathrm{e}^{-} \rightarrow \mathrm{NO}_{2}^{-}+\mathrm{NAD}(\mathrm{P})+\mathrm{H}_{2} \mathrm{O}
\end{gathered}
$$

Por ser um íon altamente reativo e potencialmente tóxico o nitrito originado da redução do nitrato é rapidamente transportado do citosol para os cloroplastos foliares e aos plastídeos, nas raízes. Nestas organelas, a NiR reduz o nitrito a amônio (TAIZ; ZEIGER, 2004). O amônio 
gerado pela assimilação do nitrato proveniente do solo, fertilizante ou da fotorrespiração é convertido rapidamente a aminoácidos, num processo que envolve a ação seqüencial da glutamina sintetase e da glutamato sintase, localizadas no citosol e nos plastídeos das raízes, e nos cloroplastos (LEA; BLACKWELL; JOY, 1992) (Figura 2). Uma vez assimilado em glutamina ou glutamato, o nitrogênio pode ser transferido para muitos outros compostos orgânicos por meio de diversas reações, como as transaminações. A interconversão entre a glutamina e a asparagina pela asparagina sintetase equilibra o metabolismo do carbono e do nitrogênio na planta.

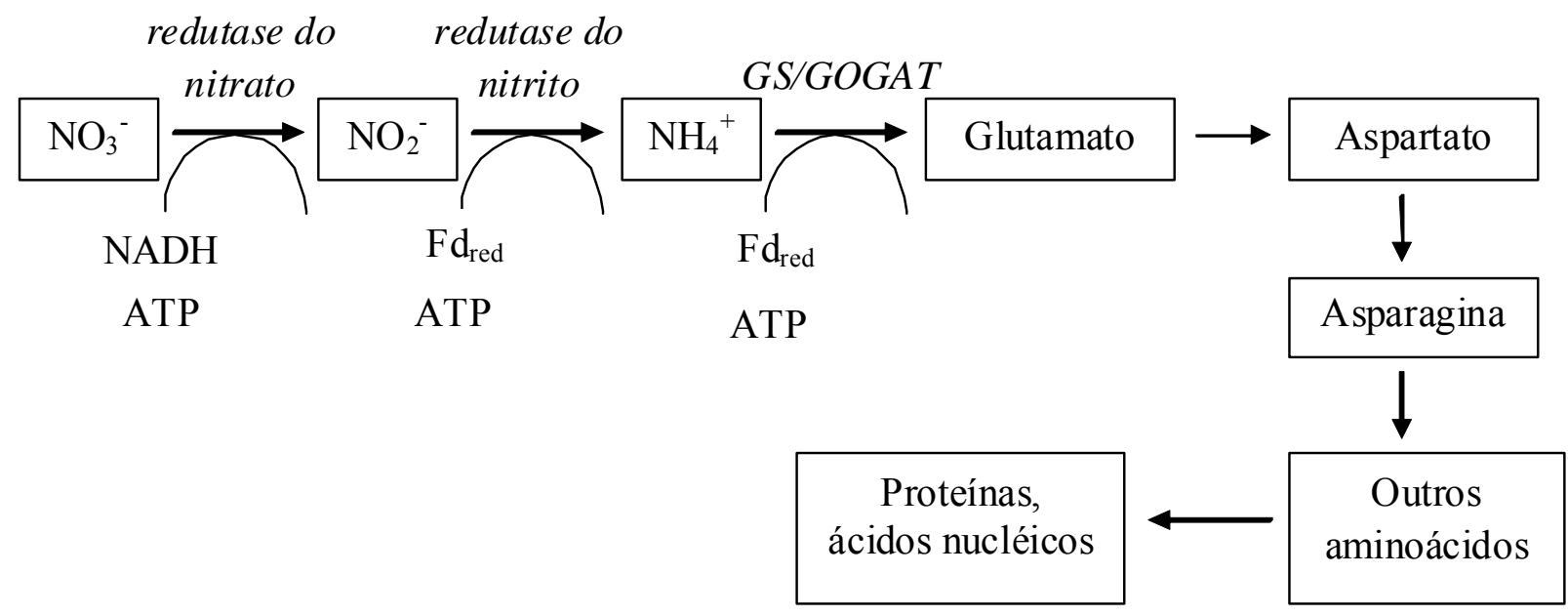

Figura 2 - Assimilação do N nas folhas (Adaptado de TAIZ; ZEIGER, 2004)

A ação da RN é o passo limitante da assimilação do nitrato e, conseqüentemente, afeta o desenvolvimento e a produção das proteínas vegetais, e pode ser usado para estimar a capacidade de assimilação de N (BEEVERS; HAGEMAN, 1980; OAKS, 1994).

A atividade da RN é regulada por inúmeros fatores, como síntese e degradação de enzimas, inativação reversível e concentração do substrato (SOLOMONSON; BARKER, 1990). Os fatores de indução da enzima são: o nitrato, a luz, o teor de água na planta, a temperatura atmosférica e a umidade do solo. A atividade da RN pode ser induzida em poucas horas após a aplicação do $\mathrm{N}$, conforme a fonte utilizada, assim como ser suprimida por alguns aminoácidos (OAKS, 1991; OAKS; WALLACE; STEVENS, 1972; BRETELER; SMIT, 1974). Segundo Silvasankar e Oaks (1996), o nitrato, a luz e a concentração de carboidrato atuam na transcrição e tradução da RN. A luz e o nível de carboidrato, além de outros fatores ambientais, estimulam a 
proteína fosfatase, que desfosforila vários resíduos de serina da $\mathrm{RN}$, o que promove a sua ativação (TAIZ; ZEIGER, 2004). Para a assimilação de amônio há uma alta demanda por cadeias carbônicas, gerando competição entre a síntese de sacarose e aminoácidos (HUCKLESBY; BLANKE, 1992).

As condições ambientais relacionada ao regime hídrico e ao conteúdo de água na planta e no solo podem provocar alterações na capacidade de assimilação de nitrato. Em experimentos realizados em Viçosa-MG, a maior atividade de $\mathrm{RN}$ na folha e a maior concentração de nitrato ocorreram durante a estação quente e seca, quando as temperaturas estão altas e há grande transpiração. Com o aumento do fluxo de água há maior fluxo de nitrato para as folhas, o que proporciona maior atividade da RN (DAMATTA; AMARAL; RENA, 1999; AMARAL; DAMATTA; RENA, 2001).

A temperatura máxima do ar próxima a $34{ }^{\circ} \mathrm{C}$ parece não afetar a tendência sazonal da atividade da RN em folhas e raízes (TALEISNIK; BRICENO; CARVAJAL, 1980; CARELLI; FAHL MAGALHÃES, 1989; AMARAL, DAMATTA; RENA, 2001). Entretanto, os períodos de baixas temperaturas afetaram a assimilação de nitrato pelas folhas, com atividade da $\mathrm{RN}$ aparentemente nula, com temperatura por volta de $15^{\circ} \mathrm{C}$ às 9:00 h (AMARAL, DAMATTA; RENA, 2001). Na pesquisa desenvolvida por Reis et al. (2009), em que se estudou a atividade de RN em cafeeiros de janeiro a junho, também foi observado decréscimo na atividade neste período, provavelmente devido a menor precipitação e diminuição da temperatura atmosférica. Além disso, a atividade da enzima neste período correlacionou positivamente com a dose de N. Freitas et al. (2007) observaram aumento da atividade da enzima a partir de outubro, em função da elevação da temperatura atmosférica e da manutenção da concentração de $\mathrm{NO}_{3}{ }^{-}$foliar, quando a concentração de $\mathrm{N}$ estava próximo aos níveis adequados.

A atividade da enzima varia com as condições de luminosidade do ambiente, com baixa atividade no escuro (STIT, 1987; SCHEIBLE; GONZÁLES-FONTES; LAUERER, 1997). Segundo Kaiser e Huber (2001), quando os demais fatores de ativação da enzima apresentam condições ótimas, a atividade da RN na luz é de aproximadamente 70 a 90 \%, com redução para 10 a $30 \%$ no escuro. Segundo estes autores, a luz não atua como sinal direto na atividade da $\mathrm{RN}$, pois mesmo sob intensa luminosidade há inativação da enzima na falta de $\mathrm{CO}_{2}$. Portanto, fatores que afetam a entrada do $\mathrm{CO}_{2}$ na planta, como abertura dos estômatos, podem interferir na atividade da enzima. O cafeeiro arábica pode apresentar menor atividade da RN sob 
luminosidade, devido a sua baixa condutância hidráulica, característica de plantas originalmente de sub-boque com elevada umidade relativa do ar (NETTO, 2005).

\subsection{Glutamina sintetase}

O amônio gerado a partir da assimilação do nitrato, da fotorrespiração, proveniente do solo e do fertilizante é rapidamente convertido em aminoácidos a fim de evitar toxidez, relacionada à rápida permeação do cátion $\left(\mathrm{NH}_{4}{ }^{+}\right)$através das membranas (HEBER et al., 1974). A formação de aminoácidos, amida e outros compostos é a principal via de detoxificação de qualquer íon amônio absorvido pela raiz ou derivado da redução do nitrato. Essa conversão se dá pela ação seqüencial de duas enzimas: (i) glutamina sintetase (GS) e (ii) glutamato sintase (GOGAT) (LEA; BLACKWELL; JOY, 1992). Estas enzimas são encontradas em raízes, cloroplastos e em organismos fixadores de $\mathrm{N}_{2}$. A GS catalisa a assimilação do $\mathrm{NH}_{4}^{+}$pelo glutamato (Glu) para formar glutamina (Gln) (Figura 2). A GOGAT transfere o grupo amida de Gln ao $\alpha$-cetoglutarato (2-GO) para, posteriormente, produzir glutamato (TEMPLE; VANCE; GANTT, 1998; IRELAND; LEA, 1999). A glutamina serve como doador de nitrogênio para a biossíntese de compostos orgânicos nitrogenados, como aminoácidos, nucleotídeos e clorofila. Assim, a enzima GS é o fator-chave para o controle da assimilação de nitrogênio pelas plantas.

$$
\text { Glutamato }+\mathrm{NH}_{4}^{+}+\mathrm{ATP} \rightarrow \text { glutamina }+\mathrm{ADP}+\mathrm{Pi}
$$

A enzima GS é encontrada como múltiplas formas de isoenzimas no citosol (GS1) e no cloroplasto ou plastídeo (GS2), onde desempenham papéis distintos (IRELAND; LEA, 1999; LANCIEN; GADAL; HODGES, 2000). A GS1 citosólica é importante na assimilação de nitrogênio pelas raízes, onde é formada a Gln, que será transportada pelo floema. A GS1 está presente principalmente em tecidos não verdes como sementes, raízes, flores e nódulos, mas também nas células companheiras do floema. A GS2 cloroplastídica tem papel crucial na reassimilação de $\mathrm{NH}_{4}{ }^{+}$liberado pela fotorrespiração (WALLSGROVE et al., 1987). A expressão da GS2 é dependente da luz e da sacarose (OLIVEIRA; CORUZZI, 1999). A enzima está envolvida na remobilização de compostos nitrogenados e sua expressão é induzida na senescência (BUCHANAN-WOLLASTON; AINSWORTH, 1997). 
A GS tem alta afinidade pelo amônio (baixo valor $\mathrm{Km}$ ) e é capaz de incorporá-lo mesmo que esteja em baixa concentração. A enzima é ativada por pH elevado e alta concentração de $\mathrm{Mg}$ e ATP, fatores que aumentam na presença da luz. A luz intensifica a redução do nitrito e produção de $\mathrm{NH}_{4}{ }^{+}$, o que requer a elevação simultânea na atividade da GS, responsável por regular a assimilação de amônio dentro dos cloroplastos (MARSCHNER, 1995). Além disso, há regulação da GS pela luz a fim de coordenar a assimilação de N inorgânico com a quantidade de carbono produzido pela fotossíntese, assim como para eliminar a toxidez do amônio produzido pela fotorrespiração. A luz pode modular a expressão gênica diretamente, pela ativação do fitocromo e criptocromo e, indiretamente, pela ativação da fotossíntese, seguido pelo aumento dos metabólitos de carbono e outras alterações nos cloroplastos (OLIVEIRA; CORUZZI, 1999).

Além da GS, a GOGAT participa também na assimilação do amônio. A enzima catalisa a transferência de grupos amida $\left(-\mathrm{NH}_{2}\right)$ da glutamina para 2-oxoglutarato (2-OG), produto do ciclo do ácido tricarboxílico. Esta reação requer ferredoxina reduzida (do fotossistema I) ou $\mathrm{NAD}(\mathrm{P}) \mathrm{H}$ (da respiração) e produz duas moléculas de glutamato, dos quais um é requerido para a manutenção do ciclo de assimilação do amônio e o outro pode ser transportado para os sítios de assimilação e usado, por exemplo, na biossíntese de proteínas (LEA; IRELAND, 1999).

Embora muitos estudos bioquímicos tenham ampliado a compreensão do metabolismo do $\mathrm{N}$, as enzimas e os processos que as regulam são ainda pouco estudados. Muitas das enzimas envolvidas na assimilação do amônio são encontradas como múltiplas formas de enzimas/isoenzimas localizados em compartimentos subcelulares ou dentro de diferentes tecidos e órgãos. $\mathrm{O}$ metabolismo do $\mathrm{C}$ e do $\mathrm{N}$ é coordenado e certas moléculas sinalizadoras como hormônios, metabólitos $\mathrm{C}$ e $\mathrm{N}$ desempenham papel importante nessa regulação. No entanto, a combinação do metabolismo do $\mathrm{C}$ e do $\mathrm{N}$ é complexa e envolve a presença de várias famílias de isoenzimas, bem como o funcionamento integrado de enzimas citosólicas e associadas a organelas.

\subsection{Urease}

A urease é uma metaloenzima que catalisa a hidrólise da uréia para formar amônio e $\mathrm{CO}_{2}$ (DIXON et al., 1975). É encontrada em vários organismos, como plantas, fungos e bactérias (HIRAYAMA et al, 2002; COX et al., 2000). A função principal da urease é permitir aos 
organismos o uso da uréia externa ou gerada internamente, como fonte de nitrogênio (MOBLEY; ISLAND; HAUSINGER, 1995; ANDREWS; BLAKELEY; ZERNER, 1984).

Em plantas, uma quantidade significativa do fluxo de nitrogênio se dá via uréia (47\% N), o qual é reciclado pela ação da urease (POLLACCO; HOLAND, 1993). A uréia pode ser formada pelo catabolismo de ureídeo, alantoato e alantoína (Figura $3 \mathrm{~A}$ ). Tem sido demonstrado que o ureídeo glicolato, um produto da degradação do alantoato é um precursor de uréia (TODD; POLLACCO, 2004; MUNOZ et al., 2006). Bloqueios genéticos e químicos da atividade da urease nas folhas causam necrose foliar, devido ao acúmulo de uréia, o que indica que a mesma tem uma significante ação no metabolismo do N (KROGMEIER; MCCARTY; BREMNER, 1989; POLLACCO; HOLLAND, 1993). No entanto, a relevância fisiológica da urease na maioria das plantas não está esclarecida. Segundo Louis (1992), o estudo do metabolismo da uréia tornase ainda mais relevante com o aumento do uso de fertilizantes à base de uréia.

A urease em plantas participa da assimilação da uréia derivada de ureídeos ou arginina (POLLACCO; HOLLAND, 1993) (Figura 3). A arginina é um importante constituinte de proteínas e um precursor para a biossíntese de poliaminas e é também um importante transportador de $\mathrm{N}$ e compostos armazenados. Uma considerável parte da arginina produzida não é reciclada, mas usada em outras rotas biossintéticas. Trigo e centeio completam seu ciclo mais cedo por translocar um substancial proporção deste $\mathrm{N}$ assimilado como citrulina, que é metabolizado via arginina e uréia (THOMPSON, 1980).

A economia de $\mathrm{N}$ pelas plantas é altamente dependente da hidrólise da uréia, a qual é prejudicada em condições de deficiência de Ni. Este último proporciona redução do metabolismo do N, acúmulo de uréia e diminuição do pool de aminoácido (GERENDÁS; SALLELMACHER, 1997; 1999). Gerendás e Sattelmacher (1997) verificaram que plantas deficientes em níquel acumulam uréia. Quando a atividade da urease é baixa, devido ao suprimento insuficiente de Ni, a uréia se acumula especialmente em plantas adubadas com uréia, o que, eventualmente, causa alteração no volume de intermediários do ciclo da ornitina. Folhas deficientes em Ni exibem altos níveis de três intermediários do catabolismo de ureídeos, como a xantina, ácido alantóico e ureideo-glicolato, uma evidência da redução da atividade enzimática nos três últimos passos do catabolismo de ureídeos (BAI; REILLY; WOOD, 2006). A atividade da arginase e da GS também são reduzidas por falta de Ni (GERENDÁS et al., 1998). 


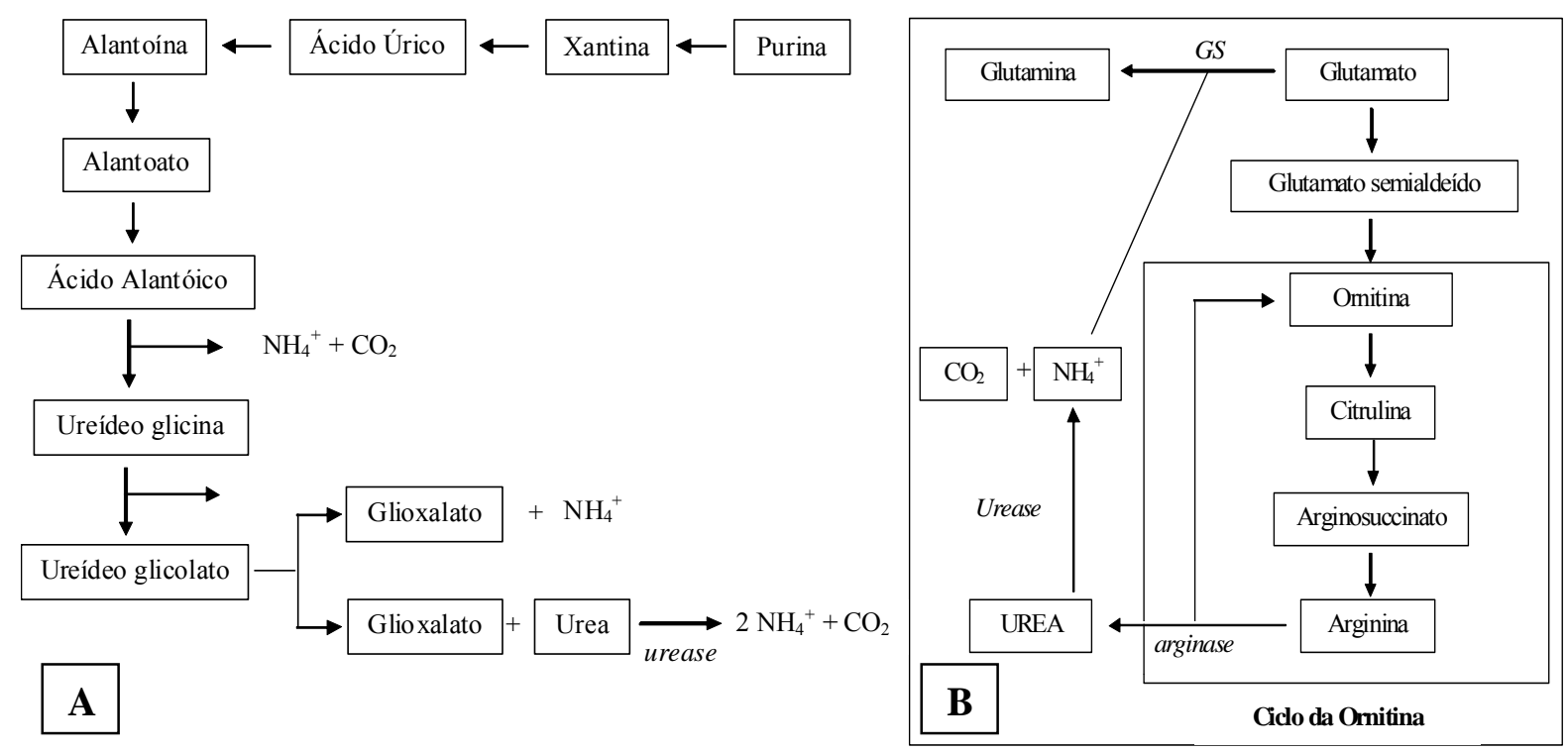

Figura 3 - Atividade da enzima urease na recuperação do $\mathrm{NH}_{4}{ }^{+}$no metabolismo do alantoína e ácido alantóico (A) recuperação do $\mathrm{NH}_{4}{ }^{+}$pelo ciclo da ornitina (B) (BAI et al., 2006)

\subsection{Relação entre carbono e nitrogênio}

O nitrogênio e o carbono, bem como a interação entre eles, estão entre os fatores que mais interferem na produtividade das culturas. O metabolismo primário do carbono é dependente da assimilação do nitrogênio, pois a maioria do $\mathrm{N}$ da planta está contido nas proteínas e clorofilas do aparato fotossintético. Por outro lado, a assimilação do nitrogênio requer um contínuo suprimento de energia e cadeias carbônicas. Isto significa que os produtos fotossintéticos podem ser particionados entre a síntese de carboidratos e aminoácidos (FOYER; FERRARIO-MERY; NOCTOR, 2001).

As folhas contêm um complexo aparato fotossintético capaz de capturar a luz e usar a energia para a redução e assimilação do $\mathrm{C}$ e N, com formação de carboidratos e aminoácidos. Nas células foliares o $\mathrm{NO}_{3}{ }^{-}$é reduzido a $\mathrm{NH}_{4}{ }^{+}$pela redutase do nitrato e nitrito, usando elétrons da cadeia transportadora de elétrons. $\mathrm{O} \mathrm{NH}_{4}{ }^{+}$é convertido a aminoácidos pela reação da GS/GOGAT, e as cadeias carbônicas são providas pelos ácidos orgânicos derivados do ciclo do ácido tricarboxílico na mitocôndria. Na síntese dos ácidos orgânicos, os carboidratos provêm da assimilação do $\mathrm{CO}_{2}$ e o ATP para a GS/GOGAT é gerado pela fotossíntese e respiração. Assim, há uma estreita interação entre o metabolismo do carbono e do nitrogênio, ambos usando energia luminosa (FOYER; FERRARIO-MERY; NOCTOR, 2001). Folhas com baixo suprimento de 
$\mathrm{NO}_{3}{ }^{-}$diminuem o conteúdo de ribulose bifosfato (RuBP), substrato para a assimilação de $\mathrm{CO}_{2}$, mas aumenta a razão ATP/ADP, o que sugere uma possível competição por um potencial redutor (MACHLER et al., 1998).

O N é necessário para a síntese de aminoácidos, proteínas e, consequentemente, de todos os componentes celulares. A rápida taxa de assimilação de $\mathrm{CO}_{2}$ requer grandes quantidades de diversos componentes dos cloroplastos, particularmente as clorofilas, as quais recebem luz; de transportadores de elétrons e de componentes dos tilacóides, que reduzem $\mathrm{NADP}^{+}$; bem como da Rubisco, que assimila o $\mathrm{CO}_{2}$ no estroma. As enzimas são reguladas de maneira complexa por fatores ambientais e das plantas. Uma eficiente captura de energia usada na fotossíntese demanda grande quantidade de clorofila por unidade de área, necessitando de um grande suprimento de $\mathrm{N}$ para garantir essa demanda.

As clorofilas têm uma complexa estrutura em anel tipo porfirina com um átomo de $\mathrm{Mg}$ coordenado no centro de 4 átomos de $\mathrm{N}$ e uma longa cauda de hidrocarbonetos hidrofóbicos, que as ancora nas membranas fotossintéticas. Os carotenóides desempenham duas funções distintas: (i) participam da absorção de luz nos complexos de captação de luz, atuando como pigmentos acessórios e (ii) desempenham papel essencial na fotoproteção do aparato fotoquímico. As clorofilas excitadas podem reagir com o oxigênio molecular e formar espécies reativas de oxigênio, destruindo componentes celulares, em especial os lipídeos da membrana. Os carotenóides, por sua vez, quando excitados dissipam a energia como calor, atuando como agentes protetores (KERBAUY, 2004).

A adubação nitrogenada afeta o crescimento e a capacidade produtiva da planta devido às alterações na área foliar e na capacidade fotossintética, com variação na concentração de clorofila. Em plantas deficientes em $\mathrm{N}$, a fotossíntese diminui devido à redução de fótons absorvidos e a queda na taxa de transporte de elétrons no cloroplasto (LU; ZHANG, 2000). A Rubisco é a principal proteína dos cloroplastos e folhas, catalisadora da reação entre $\mathrm{CO}_{2} \mathrm{e}$ $\mathrm{RuBP}$, da qual se origina a triose fosfato, que é exportado do estroma do cloroplasto para o citosol e, então, convertida em sacarose. As plantas C3 requerem uma grande quantidade de Rubisco para a assimilação do $\mathrm{CO}_{2}$, a qual pode ser prejudicada caso o suprimento de $\mathrm{N}$ não seja adequado (LAWLOR et al., 1988; LAWLOR; KONTTURI; YOUNG, 1989). A temperatura também pode influenciar a atividade da enzima, pois sob baixa temperatura, uma quantidade superior de proteínas é requerida para manter uma dada taxa de assimilação de $\mathrm{CO}_{2}$. 
Em condições de deficiência de $\mathrm{N}$ há redução na assimilação total, já que as folhas têm curta duração, senescem e perdem componentes fotossintéticos, em razão da remobilização de $\mathrm{N}$ para os órgãos em crescimento (BROUQISSE et al., 2001). Durante as fases de desenvolvimento dos frutos há redução das concentrações foliares de clorofila $a, b$ e total, fotossíntese e nitrogênio foliar. Para Reis (2007), essa diminuição se dá no início da senescência, a qual é antecipada quando as plantas estão deficientes em N. Feller e Keist (1986) sugerem a existência de controle fisiológico, no qual as células remobilizam frações de baixo peso molecular como aminoácidos para o enchimento dos grãos, sendo o $\mathrm{N}$ o principal nutriente requerido nesta fase fenológica.

\subsection{Fenologia e concentração foliar de nutrientes}

A concentração dos nutrientes em folhas e frutos do cafeeiro durante o ciclo vegetativo é uma importante ferramenta para diagnose do estado nutricional da planta, a partir da qual se pode estimar as necessidades nutricionais da cultura e identificar os períodos adequados para aplicação dos fertilizantes.

O cafeeiro completa seu ciclo fenológico em dois anos. No primeiro ano são formados os ramos vegetativos, com gemas axilares presentes acima dos nós. Essas gemas são induzidas em gemas reprodutivas por fotoperiodismo. As gemas florais maduras entram em dormência e ficam prontas para a antese, quando ocorre um aumento do potencial hídrico das gemas. As mudanças causadas por chuva ou irrigação desencadeiam a florada, quando inicia o segundo ano fenológico. $\mathrm{Na}$ sequência ocorre a fase de chumbinho, expansão, granação dos frutos e maturação (CAMARGO; CAMARGO, 2001). Numa mesma planta existem ramos na fase vegetativa e ramos na fase reprodutiva, logo o fornecimento de nutrientes deve atender a demanda dos frutos e dos órgãos vegetativos, de maneira que as adubações antecedam os picos de demanda dos nutrientes.

As flores desenvolvem-se com as primeiras chuvas da primavera e para isso, a planta depende do acúmulo de compostos durante o inverno. Neste período, as raízes acumulam compostos nitrogenados, como aminoácidos e reguladores de crescimento e transporta-os para a parte aérea, contribuindo para o crescimento no início da primavera (AMARAL, 1991; DAMATTA; AMARAL; RENA, 1999).

A demanda de macronutrientes pela planta aumenta na fase de expansão, entretanto, a maior necessidade se dá no estádio de granação do fruto. Segundo Carvalho et al. (1993), na fase 
reprodutiva os frutos são drenos preferenciais de carboidratos e nutrientes minerais, com possibilidade de haver carência de nutrientes em outros órgãos da planta. Em razão da alta demanda tem início o processo de redistribuição do $\mathrm{N}$, na forma de aminoácido, de outros órgãos da planta como, por exemplo, das folhas para os frutos. A senescência, associada à maturação, causa danos a biologia da planta, mas constitui fator importante à produtividade das culturas em razão do enchimento dos frutos (LEA; MOROT-GAUDRY, 2001).

Os micronutrientes são requeridos em pequenas quantidades pelas plantas, mas desempenham papel fundamental no metabolismo, como constituinte de enzimas ou atuando como ativadores. Os micronutrientes são também importantes para o desenvolvimento e produção do cafeeiro. De forma geral, as lavouras cafeeiras no Brasil são implantadas em solos com baixa disponibilidade de micronutrientes, devido ao baixo teor disponível no solo ou por outros fatores, como a calagem, que limitam a sua absorção, pela redução na disponibilidade de micronutrientes (MARTINEZ et al., 2003).

Cada fase de formação do fruto possui funções fisiológicas e metabólicas próprias, essenciais à sua formação (CANNEL, 1971). Estas fases podem sofrer alterações de acordo com as características climáticas. Segundo Larcher (2004) a temperatura influencia o crescimento e desenvolvimento do fruto, devido ao efeito nos processos regulatórios das plantas. Em condições de altas temperaturas a velocidade das reações enzimáticas aumenta, assim como há alterações nas taxas fotossintéticas e respiratórias. Segundo Marenco e Lopes (2005), o aumento da temperatura acelera a taxa respiratória da planta, incrementa o metabolismo nas raízes e a produção de ATP, e libera energia usada para absorção de íons. No entanto, quando a temperatura é superior a $40{ }^{\circ} \mathrm{C}$ há redução da velocidade de respiração, devido à inativação de enzimas envolvidas no processo respiratório, com diminuição na produção de ATP, desnaturação de proteínas e danos à membrana plasmática. Além disso, a temperatura também pode alterar a taxa de transporte de nutrientes e a partição de fotoassimilados no floema.

Além da temperatura, outros fatores, como a disponibilidade hídrica influencia a absorção e a distribuição dos nutrientes na planta, bem como no desenvolvimento do fruto. $\mathrm{O}$ suprimento de água via irrigação, em quantidades e intervalos necessários, pode proporcionar grandes aumentos de produtividade na cafeicultura, além de menores perdas para a planta (SOARES et al., 2005). A altitude também modifica a demanda da planta por nutrientes, uma vez que a mesma influencia a duração do ciclo reprodutivo do cafeeiro, bem como o acúmulo de macronutrientes 
nos frutos, que ocorre precocemente nas menores altitudes (LAVIOLA et al., 2008). Portanto, o consumo de nutrientes pelos frutos e o enchimento dos grãos é mais crítico nessas altitudes, já que a planta completa seu ciclo em menos tempo. 


\section{MATERIAL E MÉTODOS}

\section{1 Área experimental}

Para realização desta pesquisa foram conduzidos dois experimentos. O primeiro foi realizado no município de Luiz Eduardo Magalhães, no Oeste do Estado da Bahia e o segundo na área experimental da Escola Superior de Agricultura "Luiz de Queiroz", da Universidade de São Paulo, em Piracicaba - SP.

\subsubsection{Experimento 1 - Oeste baiano}

O experimento foi conduzido de agosto de 2008 a julho de 2009, na Fazenda Morena, do Grupo Arakatu Ltda, no município de Luiz Eduardo Magalhães - BA. Nesta pesquisa utilizaramse plantas da espécie Coffea arabica L., variedade Catuaí Vermelho H-2077-144, de sete anos, no espaçamento $3,8 \times 0,5 \mathrm{~m}$, num total de 5.263 plantas por hectare, em arranjo circular, sob pivô central, para irrigação e fertirrigação direcionadas nas plantas (Figura 4).

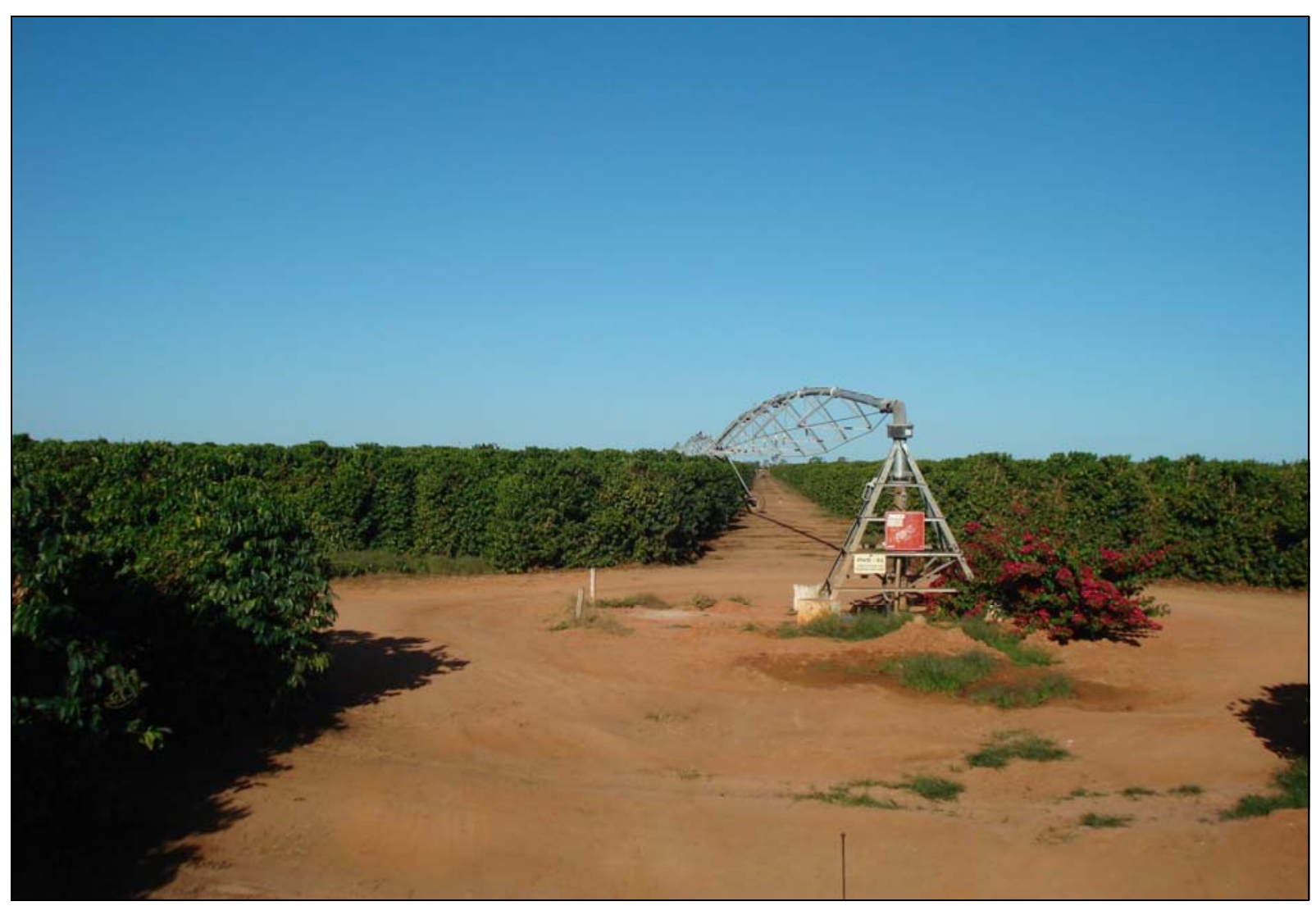

Figura 4 - Cafezal sob pivô central na Fazenda Morena, onde foi instalado o experimento 
De acordo com a classificação de Köppen, o clima regional é do tipo Aw, quente e úmido na estação chuvosa e estação seca no inverno. Essa condição climática predomina em todo o Oeste baiano, com exceção da parte setentrional e do Vale do Rio São Francisco. A área experimental está localizada a $740 \mathrm{~m}$ de altitude, com temperatura média anual de $23{ }^{\circ} \mathrm{C}$ e precipitação pluvial média de $1.500 \mathrm{~mm}$ anuais (Figura 5). O solo da área experimental é classificado como Latossolo Vermelho Amarelo distrófico típico, álico, textura média, cujos resultados da análise estão apresentados na Tabela 2.

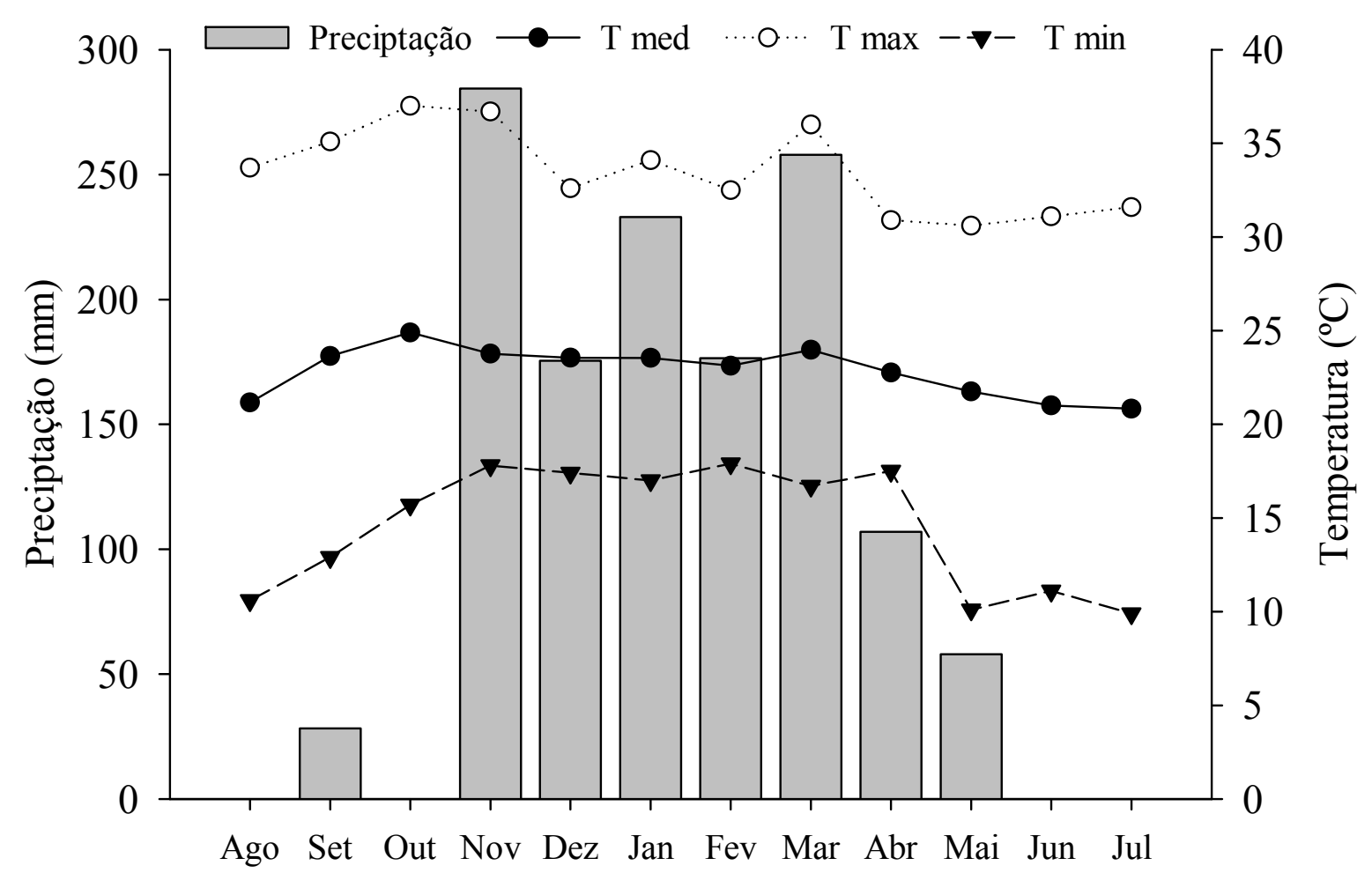

Figura 5 - Precipitação $(\mathrm{mm})$ e temperatura média, máxima e mínima $\left({ }^{\circ} \mathrm{C}\right)$ no período de realização do experimento (agosto/2008 a julho/2009), na Fazenda Morena, em Luís Eduardo Magalhães-BA

A fertirrigação foi realizada com auxílio de emissores do tipo LEPA ("low energy precision application" ou aplicação precisa de baixo consumo de energia) que distribuem a água de forma localizada sobre as linhas circulares do cafeeiro, de modo que as entrelinhas não recebem água. A irrigação foi realizada durante o ano, com uma pequena interrupção durante a colheita, fornecendo uma lâmina de 3 a $4 \mathrm{~mm} \mathrm{dia}^{-1}$, em dias alternados. 
A fertirrigação com fonte nitrogenada foi realizada de 15 em 15 dias, num total de 26 fertirrigações no ano, com a primeira aplicação feita no dia 01 de agosto de 2008 e a última em 17 de julho de 2009 (Tabela 1). Para a execução do experimento, usou-se um registro individual em cada linha, para suspensão da fertirrigação na linha do experimento. Dessa forma, não houve sobreposição de $\mathrm{N}$ mineral utilizado pela propriedade com o $\mathrm{N}$ aplicado no experimento. As demais adubações foram realizadas de acordo com a tabela 3.

Para a instalação do experimento usou uréia marcada com o isótopo estável ${ }^{15} \mathrm{~N}$, aplicada em uma linha de café, num arco de $120 \mathrm{~m}$ de comprimento, em que 240 cafeeiros em renque não receberam a fertirrigação nos moldes tradicionais da propriedade. A uréia marcada $\operatorname{com}{ }^{15} \mathrm{~N}$ foi produzida no Laboratório de Isótopos Estáveis do CENA/USP. O ${ }^{15} \mathrm{~N}$ foi aplicado manualmente, após a diluição do adubo em volume de água semelhante à quantidade aplicada na irrigação, a qual também era feita quinzenalmente, nas mesmas épocas que a propriedade efetuava a fertirrigação.

Cada parcela, com distribuição casual ao longo da linha do cafeeiro, foi constituída de 3 plantas centrais a cada 11 plantas, com 4 plantas de bordadura de cada lado (Figura 6).

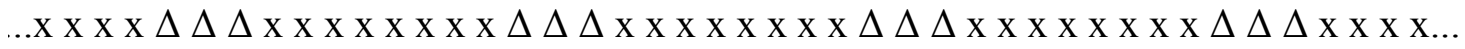

Figura 6 - Esquema representativo da parcela no campo, onde $\mathrm{x}$ representa as plantas de cafeeiro da bordadura; e $\Delta$, as plantas de cafeeiro que receberam as doses de $\mathrm{N}$

O experimento foi implantado de acordo com delineamento inteiramente casualizado, com 5 tratamentos e 4 repetições. Os tratamentos corresponderam às seguintes doses de $\mathrm{N}$ : $\mathrm{T}_{0}-\mathrm{sem}$ adubação nitrogenada; $\mathrm{T}_{1}-200 \mathrm{~kg} \mathrm{ha}^{-1}$, que equivale a $38 \mathrm{~g}_{\text {planta }}{ }^{-1} \mathrm{de} \mathrm{N}\left(84 \mathrm{~g}_{\text {planta }}{ }^{-1}\right.$ de uréia); $\mathrm{T}_{2}-400 \mathrm{~kg} \mathrm{ha}^{-1}$ (169 $\mathrm{g}_{\text {planta }}{ }^{-1}$ de uréia); $\mathrm{T}_{3}-600 \mathrm{~kg} \mathrm{ha}^{-1}\left(253 \mathrm{~g} \mathrm{planta}^{-1}\right.$ de uréia); $\mathrm{T}_{4}-800 \mathrm{~kg}$ $\mathrm{ha}^{-1}$ (338 $\mathrm{g}_{\text {planta }}{ }^{-1}$ de uréia). Esses cálculos foram feitos com base no espaçamento de plantio ( $3,8 \times 0,5 \mathrm{~m})$; que corresponde a uma população de 5.263 plantas por hectare (Tabela 1).

As coletas foram feitas em cada uma das fases fenológicas do cafeeiro e após a colheita, totalizando seis coletas, e estas foram efetuadas nos dias 18 de agosto de 2008 (56 dias antes da antese: -56 DRA, ainda na fase vegetativa), 13 de outubro de 2008 (0 DRA, na antese), 24 de novembro (42 DRA, fruto chumbinho), 16 de fevereiro de 2009 (126 DRA, na granação), 30 de março de 2009 (168 DRA, ainda na granação) e 6 de julho de 2009 (266 DRA - maturação). A 
coleta em diferentes épocas, combinadas as várias doses utilizadas, resultou em um esquema de parcela subdividida no tempo.

Tabela 1 - Quantidade de $\mathrm{N}$ aplicado $\left(\mathrm{kg} \mathrm{ha}^{-1}\right)$ em cada fase fenológica em razão dos tratamentos (sem N, 200, 400, 600 e $\left.800 \mathrm{~kg} \mathrm{ha}^{-1} \mathrm{de} \mathrm{N}\right)$

\begin{tabular}{|c|c|c|c|c|c|c|c|c|}
\hline \multirow{2}{*}{ Fenologia } & \multirow{2}{*}{$\begin{array}{l}\text { Dias em } \\
\text { relação } \\
\text { à antese }\end{array}$} & \multirow{2}{*}{ Aplicação } & \multirow{2}{*}{$\begin{array}{l}\% \text { do } \mathrm{N} \\
\text { aplicado }\end{array}$} & \multicolumn{5}{|c|}{$\mathrm{N}$ aplicado $\left(\mathrm{kg} \mathrm{ha}^{-1}\right)$} \\
\hline & & & & 0 & 200 & 400 & 600 & 800 \\
\hline Vegetação & -56 & 18/ago & 7,7 & - & 15,4 & 30,8 & 46,2 & 61,6 \\
\hline Antese & 0 & $13 /$ out & 23,1 & - & 46,2 & 92,4 & 138,6 & 184,8 \\
\hline Chumbinho & 42 & $24 / \mathrm{Nov}$ & 34,7 & - & 69,4 & 138,8 & 208,2 & 277,6 \\
\hline Granação 1 & 126 & $16 / \mathrm{fev}$ & 57,8 & - & 115,6 & 231,2 & 346,8 & 462,4 \\
\hline Granação $_{2}$ & 168 & $30 /$ mar & 69,3 & - & 138,6 & 277,2 & 415,8 & 554,4 \\
\hline Maturação & 266 & 06/jul & 96,25 & - & 192,5 & 385,0 & 577,5 & 770,0 \\
\hline
\end{tabular}

O regime hídrico foi acompanhado pelo registro das irrigações/fertirrigações, por meio da coleta de dados da estação meteorológica automática, presente na Fazenda.

As análises realizadas no experimento foram: (i) concentrações foliares de N-total, Nnitrato e $\mathrm{N}$-amoniacal (ii) aminoácidos totais solúveis; (iii) redutase do nitrato; (iv) glutamina sintetase; (v) urease; (vi) clorofila; (vii) carotenóides; (viii) concentrações foliares de macro e micronutrientes; e (ix) condutância estomática. 
Tabela 2 - Resultados da análise do solo da área experimental em diferentes profundidades

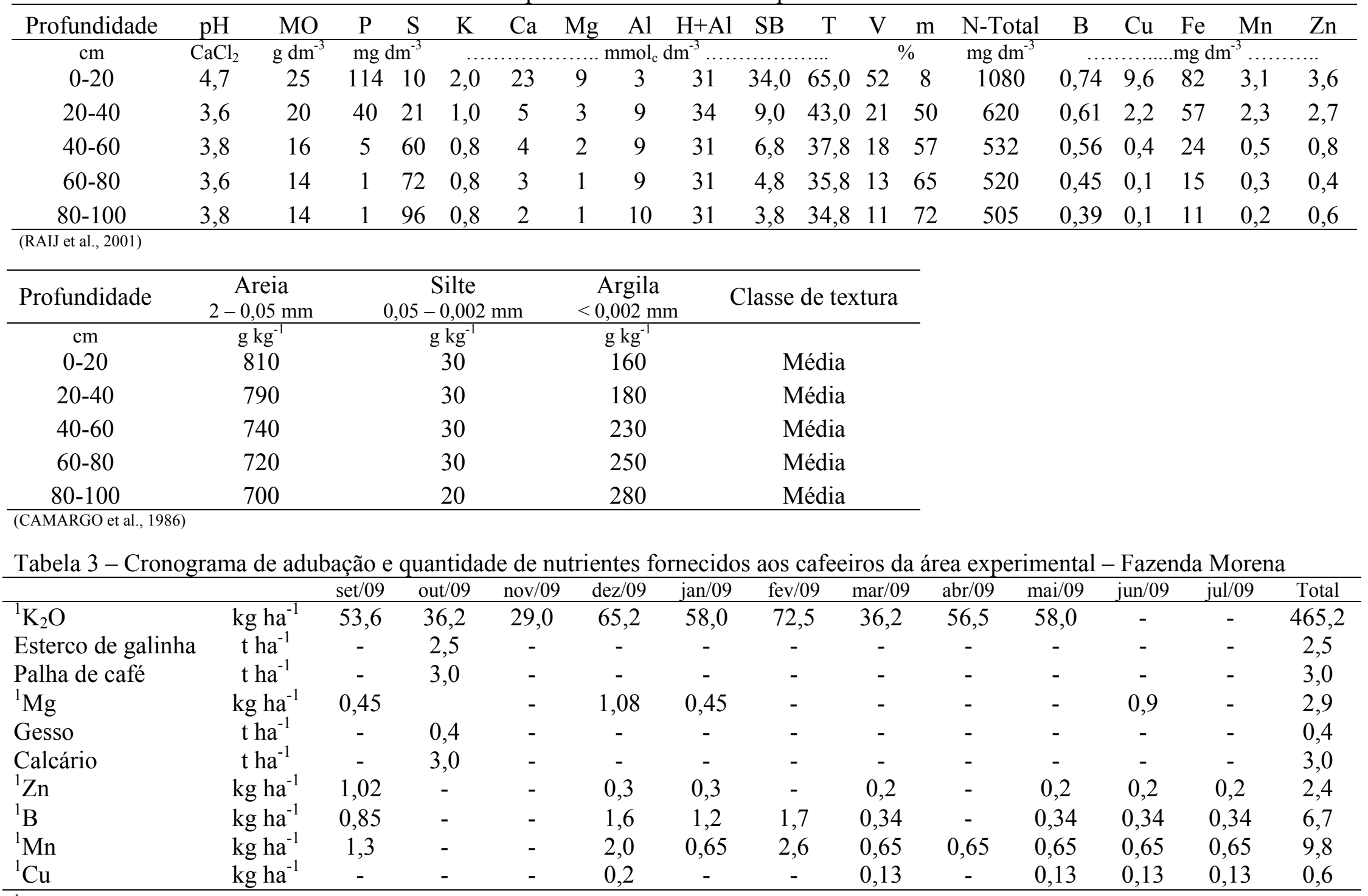

${ }^{1}$ via fertirrigação 


\subsubsection{Experimento 2 - Piracicaba}

O experimento de Piracicaba foi instalado com a finalidade de complementar os dados obtidos no experimento no Oeste baiano e conduzido de fevereiro a julho de 2009, na Escola Superior de Agricultura "Luiz de Queiroz", município de Piracicaba - SP, situada a 2242’30" de latitude Sul e $47^{\circ} 38^{\prime} 00^{\prime \prime}$ de longitude Oeste e altitude média de $580 \mathrm{~m}$. De acordo com a classificação de Köppen o clima regional é do tipo Cwa, tropical de altitude com inverno seco, temperatura média anual de $22{ }^{\circ} \mathrm{C}$ e precipitação pluvial média de $1.280 \mathrm{~mm}$ anuais (Figura 7). Nesta pesquisa foram utilizadas plantas da espécie Coffea arabica L. cv. Obatã IAC 1669-20, com sete anos, no espaçamento $3,4 \times 0,9 \mathrm{~m}$, com 3.268 plantas por hectare. $\mathrm{O}$ solo da área experimental é classificado como Nitossolo Vermelho, Eutroférrico, latossólico, textura argilosa, cujos resultados da análise química estão apresentados na tabela 4.

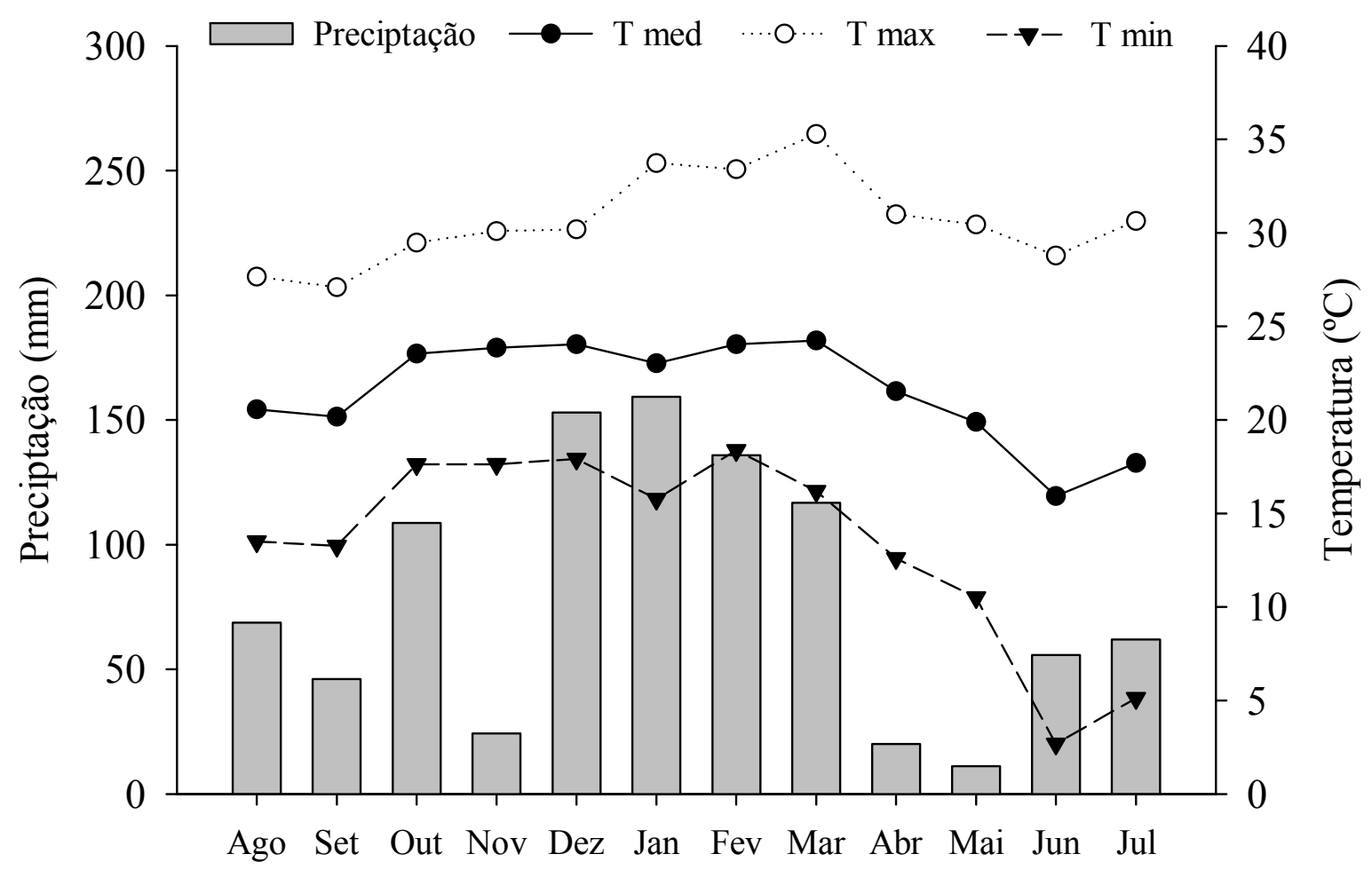

Figura 7 - Precipitação $(\mathrm{mm})$ e temperatura média, máxima e mínima $\left({ }^{\circ} \mathrm{C}\right)$ da área experimental da ESALQ/USP, em Piracicaba-SP, no período de agosto/2008 a julho/2009

Os dados de fertilidade do solo da área experimental estão apresentados na tabela 4. Em setembro de 2008 foi aplicado calcário e gesso agrícola. A adubação nitrogenada e potássica 
foram realizadas em fevereiro, sendo o nitrogênio aplicado na forma de uréia em uma única aplicação. Cada parcela foi constituída de 7 plantas, das quais 5 foram avaliadas (Figura 8).

$$
\ldots . . \times \Delta \Delta \Delta \Delta \mathrm{x} \ldots \mathrm{x} \Delta \Delta \Delta \Delta \Delta \mathrm{x} \ldots \mathrm{x} \Delta \Delta \Delta \Delta \Delta \mathrm{x} \ldots \mathrm{x} \Delta \Delta \Delta \Delta \Delta \mathrm{x} \ldots
$$

Figura 8 - Esquema representativo da parcela no campo, onde $\mathrm{x}$ representa as plantas de cafeeiro da bordadura; e $\Delta$, as plantas de cafeeiro avaliadas

Os tratamentos utilizados foram: $\mathrm{T}_{0}$ - sem adubação nitrogenada; $\mathrm{T}_{1}-200 \mathrm{~kg} \mathrm{ha}^{-1}$, que equivale a $61 \mathrm{~g}$ planta $^{-1}$ de N (136 g planta ${ }^{-1}$ de uréia); $\mathrm{T}_{2}-800 \mathrm{~kg} \mathrm{ha}^{-1}\left(544 \mathrm{~g} \mathrm{planta}^{-1}\right.$ de uréia). $\mathrm{O}$ experimento foi implantado em delineamento inteiramente casualizado, com três tratamentos e cinco repetições, em esquema de parcelas subdivididas no tempo.

A aplicação da uréia nas parcelas foi realizada em uma única adubação no dia 26 de fevereiro de 2009, com as amostragens efetuadas de março a junho, num total de cinco coletas, nos dias 02 de março de 2009 (4 dias após a adubação - DAAd), 16 de março de 2009 (18 DAAd), 16 de abril de 2009 (49 DAAd), 28 de maio de 2009 (91 DAAd) e 14 de julho de 2009 (138 DAAd).

Para avaliação da atividade da enzima RN foram realizadas coletas com 1, 4, 18, 55, $91 \mathrm{e}$ 138 dias após a adubação (DAAd) com o objetivo de verificar o pico da atividade da RN após a aplicação do N.

A uréia foi aplicada manualmente, após sua diluição em água, com a finalidade de simular uma aplicação sob chuva, para evitar as perdas por volatilização. O regime hídrico foi acompanhado por meio da coleta de dados da estação meteorológica automática e realizou-se 3 irrigações nos períodos de déficit hídrico acentuado.

Neste experimento realizou-se as seguintes avaliações: (i) concentrações foliares de Ntotal, N-nitrato e N-amoniacal; (ii) aminoácidos totais solúveis e (iii) redutase do nitrato. 
Tabela 4 - Resultados da análise química do solo da área experimental em diferentes profundidades

\begin{tabular}{|c|c|c|c|c|c|c|c|c|c|c|c|c|c|c|c|}
\hline Profundidade & $\mathrm{pH}$ & M.O & $\mathrm{P}$ & $\mathrm{K}$ & $\mathrm{Ca}$ & $\mathrm{Mg}$ & $\mathrm{Al}+\mathrm{H}$ & SB & CTC & V & B & $\mathrm{Cu}$ & $\mathrm{Fe}$ & $\mathrm{Mn}$ & $\mathrm{Zn}$ \\
\hline $\mathrm{cm}$ & $\mathrm{CaCl}_{2}$ & $\mathrm{~g} \mathrm{dm}^{-3}$ & $\mathrm{mg} \mathrm{dm}^{-3}$ & \multicolumn{6}{|c|}{.. mmolc $\mathrm{dm}^{-3} \ldots$. } & $\%$ & & & $\mathrm{mg}$ & & \\
\hline $0-5$ & 5,1 & 38 & 74 & 5,2 & 72 & 25 & 40 & 101,9 & 142,2 & 71 & 0,57 & 4,8 & 41 & 59,9 & 3,8 \\
\hline $5-15$ & 4,9 & 23 & 66 & 5,3 & 39 & 13 & 38 & 56,6 & 95,1 & 60 & 0,46 & 9,8 & 25 & 69,1 & 12,5 \\
\hline $15-25$ & 5,1 & 21 & 58 & 6,1 & 38 & 12 & 31 & 56,1 & 87,7 & 64 & 0,41 & 4,8 & 29 & 60,1 & 20,8 \\
\hline $25-50$ & 5,2 & 14 & 9 & 5,0 & 25 & 8 & 24 & 37,3 & 61,0 & 61 & 0,34 & 2,4 & 11 & 22,3 & 1,8 \\
\hline $50-100$ & 5,4 & 10 & 5 & 3,0 & 16 & 5 & 20 & 24,3 & 44,2 & 55 & 0,35 & 1,1 & 5 & 5,4 & 0,3 \\
\hline
\end{tabular}

(RAIJ et al., 2001) 


\subsection{Material vegetal}

Para determinação das concentrações de aminoácidos e macro e micronutrientes coletouse o terceiro par de folhas de ramos a meia altura das plantas de cada parcela (Figura 9 A), as quais foram acondicionadas em saquinhos de tecido voil com zíper, previamente identificadas e, em seguida, conservadas em nitrogênio líquido (Figura 9 B). As folhas congeladas foram, posteriormente, armazenadas em freezer a $-80{ }^{\circ} \mathrm{C}$, enquanto aguardavam para serem liofilizadas. Os materiais foram liofilizados sob pressão de 803 bar e à temperatura de $-47^{\circ} \mathrm{C}$, durante 24 horas em liofilizador Heto Lab Equipamentos, FD 4.0. e em seguida, moídas em moinho de faca (Marconi, MA 630) e acondicionadas em frascos de acrílico com tampa de plástico.

Para as análises de redutase do nitrato, urease, clorofila e carotenóides foram coletados o terceiro par de folhas de ramos a meia altura das plantas de cada parcela, as quais foram acondicionadas em caixas de isopor para transporte ao laboratório.

Para determinação da enzima glutamina sintetase coletou-se o terceiro par de folhas de ramos a meia altura das plantas de cada parcela. Os materiais coletados foram acondicionados em envelopes de papel alumínio, previamente identificados e, em seguida, mantidos em nitrogênio líquido e armazenados em freezer a $-80{ }^{\circ} \mathrm{C}$ até a realização da análise.
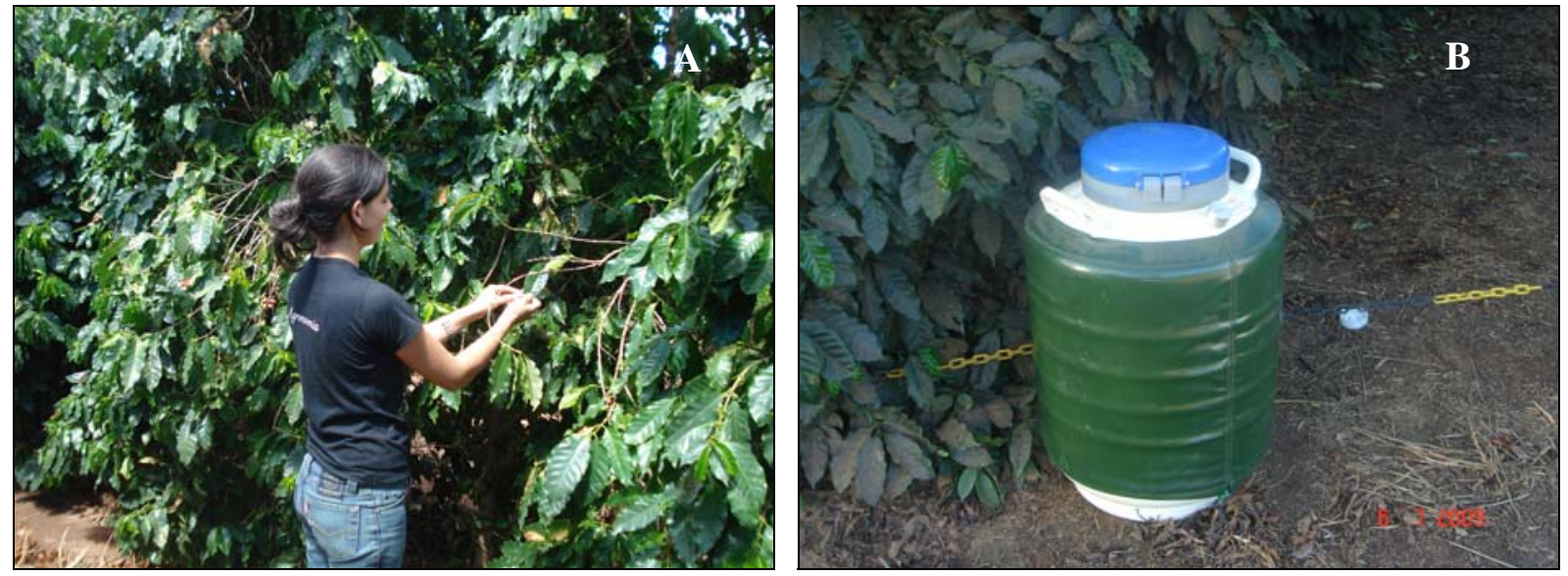

Figura 9 - Coleta de material na área experimental (A) e tambor de $\mathrm{N}$ líquido para acondicionar as amostras de material durante o transporte (B)

\subsection{Metodologias}

\subsubsection{Extração e determinação da atividade da redutase do nitrato (RN; EC 1.6.6.1)}

A determinação da atividade da redutase do nitrato $(\mathrm{RN})$ foi feita segundo o ensaio in vivo modificado por Radin (1974). No experimento na Bahia, as amostras de folhas foram coletadas às 
7:00, 12:00, 17:00 e 22:00 h. Esse procedimento foi adotado para verificar as flutuações na atividade da enzima durante o dia e em cada fase fenológica. As amostras de tecidos frescos foram coletadas em caixas de isopor e transportadas para o laboratório. No experimento feito na ESALQ, as amostras foram coletadas às 9:00 h, nos dias 1, 4, 18, 55, 91 após a adubação, com a finalidade de verificar o pico da atividade dessa enzima, depois da aplicação do fertilizante.

Para esta análise utilizou-se $100 \mathrm{mg}$ de massa fresca, obtidas em discos foliares, utilizando-se furador de rolhas (Figura $10 \mathrm{~A}$ ), os quais foram colocados em tubos de ensaio contendo 5,0 mL de solução tampão fosfato $50 \mathrm{mM}, \mathrm{pH} 7,4+\mathrm{KNO}_{3} 200 \mathrm{mM}$. Esse tampão possui nitrato, substrato para a enzima $\mathrm{RN}$, que converte nitrato em nitrito. Em seguida, os tubos de ensaios contendo o material vegetal foram incubados em banho-maria a $37^{\circ} \mathrm{C}$ por 30 minutos, protegidos da luz com folhas de alumínio ao redor dos tubos. Esse procedimento foi utilizado com a finalidade de padronizar a quantidade de luz recebida pelos tubos.

Após permanecer 30 minutos em banho-maria, os tubos foram retirados e a paralisação da reação foi feita com a adição de $1,0 \mathrm{~mL}$ de sulfanilamida $(58 \mathrm{mM})$ a $1 \% \mathrm{em} \mathrm{HCl} 2 \mathrm{~N}\left(2 \mathrm{~mol} \mathrm{~L}^{-1}\right)$ e a seguir, adicionou-se $1 \mathrm{~mL}$ de $\mathrm{N}$ - $\alpha$-naftiletilenodiamina $(1,93 \mathrm{mM})$, que confere coloração ao nitrito e permite sua leitura. A leitura de absorbância da reação foi feita em espectrofotômetro a $540 \mathrm{~nm}$, e a atividade da enzima determinada pela quantidade de nitrito $\left(\mathrm{NO}_{2}^{-}\right)$produzida, a qual foi comparada com os valores obtidos em uma curva padrão de nitrito, preparada previamente com $\mathrm{NaNO}_{2} 10 \mu \mathrm{M}$ (Figura $10 \mathrm{~B}$ ). Os resultados obtidos foram expressos em $\mu \mathrm{mol} \mathrm{NO}{ }_{2}^{-} \mathrm{h}^{-1} \mathrm{~g}^{-1}$ MF.
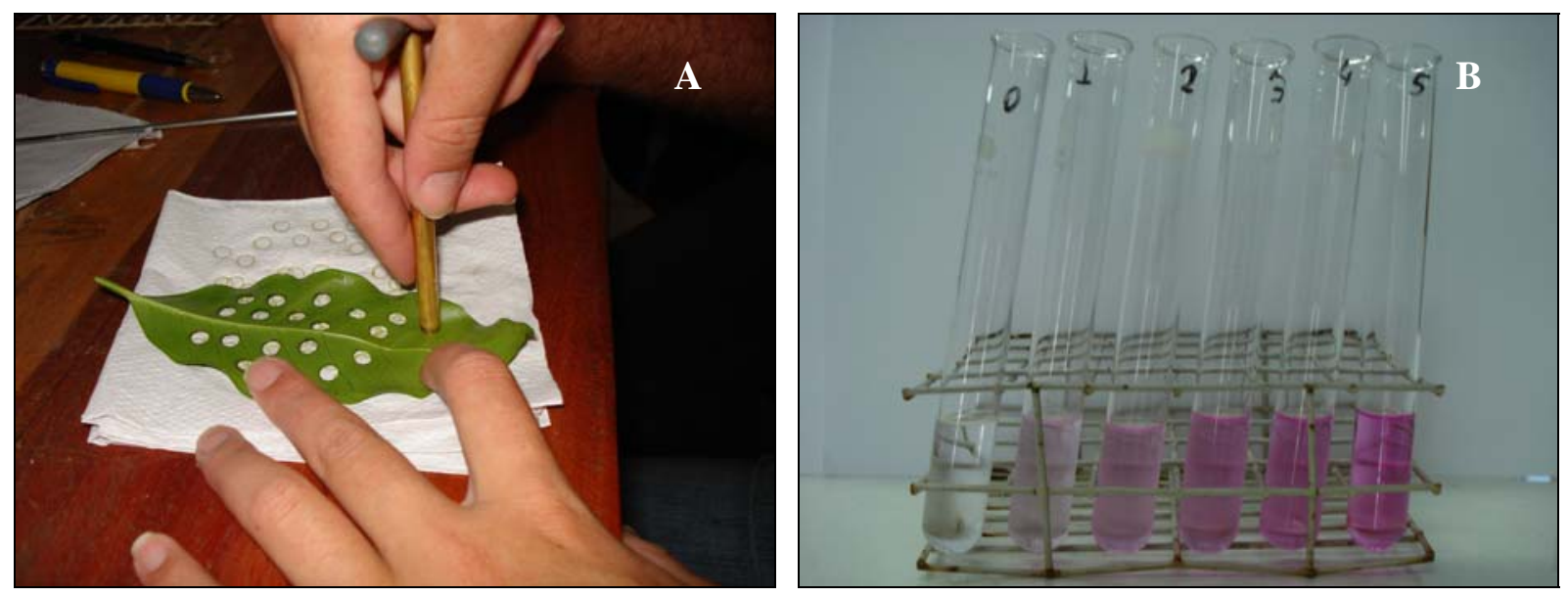

Figura 10 - Procedimentos usados para a avaliação de RN. Obtenção de discos foliares com furador do tipo rolha (A) e solução para obtenção de curva padrão de nitrito (B) 


\subsubsection{Determinação da atividade da urease (EC 3.5.1.5)}

A atividade da urease foi determinada in vivo segundo metodologia adaptada de Hogan et al. (1983) e baseada na medida de amônia derivada da hidrólise enzimática da uréia.

As amostras de tecidos frescos foram coletadas às 9:00 $\mathrm{h}$ em caixas de isopor e transportadas até o laboratório na fazenda. Posteriormente, $100 \mathrm{mg}$ de massa fresca, obtidas com discos foliares, que foram colocados em tubos de ensaio contendo $8 \mathrm{~mL}$ de tampão fosfato com uréia $(\mathrm{pH} 7,4)$ para determinação do teor de $\mathrm{NH}_{3}$. O tampão foi preparado com $\mathrm{NaH}_{2} \mathrm{PO}_{4}(0,20$ M), $\mathrm{Na}_{2} \mathrm{HPO}_{4}(0,50 \mathrm{M})$, n-propanol $(0,66 \mathrm{M})$, uréia $(0,21 \mathrm{M})$. A solução tampão contém npropanol, a fim de aumentar a permeabilidade dos tecidos e evitar a formação de amônia pela presença de contaminantes microbianos. As amostras foram incubadas em banho-maria a $30{ }^{\circ} \mathrm{C}$ por 3 horas, protegidas da luz com folhas de alumínio ao redor dos tubos, com agitação constante.

A determinação do $\mathrm{N}_{-} \mathrm{NH}_{4}$ foi realizada conforme metodologia descrita por McCullough (1967). Após a incubação, retirou-se uma alíquota de $0,5 \mathrm{~mL}$ do extrato e a amônia retida nos tecidos foliares foi extraída pela adição de $2,5 \mathrm{~mL}$ do Reagente I: Fenol 0,1 M, nitroprussiato de

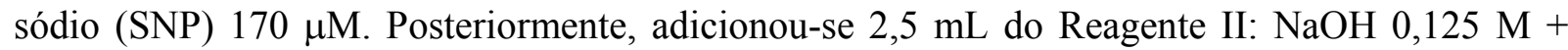
$\mathrm{Na}_{2} \mathrm{HPO}_{4} \cdot 12 \mathrm{H}_{2} \mathrm{O} 0,15 \mathrm{M}+\mathrm{NaOCl}\left(3 \% \mathrm{Cl}_{2}\right)$. Os tubos foram tampados com bolas de vidro para evitar a perda de $\mathrm{NH}_{3}$ e deixados em banho-maria a $37^{\circ} \mathrm{C}$, por 35 minutos e em seguida realizouse a leitura colorimétrica da reação, em espectrofotômetro a $625 \mathrm{~nm}$. A atividade da enzima foi determinada pela quantidade de amônio $\left(\mathrm{NH}_{4}{ }^{+}\right)$produzida e, os valores obtidos, foram comparados com uma curva padrão, previamente estabelecida, utilizando-se $\mathrm{NH}_{4} \mathrm{Cl}$ como padrão de amônio. Os resultados obtidos foram expressos em $\mu \mathrm{mol} \mathrm{NH}{ }_{4}^{+} \mathrm{h}^{-1} \mathrm{~g}^{-1} \mathrm{MF}$.

\subsubsection{Preparo dos extratos para análise de glutamina sintetase e proteína}

Em cada tratamento coletou-se $1,0 \mathrm{~g}$ de material vegetal em nitrogênio líquido, armazenados em freezer a $-80{ }^{\circ} \mathrm{C}$. Posteriormente, as amostras foram fracionadas e maceradas em graal de porcelana, usando uma pequena quantidade de nitrogênio líquido durante a maceração. Após a evaporação do $\mathrm{N}$ líquido adicionou-se $2,0 \mathrm{~mL}$ da solução de extração, feita com tampão TRIS - HCl, 50 mM, pH 7,5; Mercaptoetanol, 2 mM; EDTA, 1 mM.

O material foi homogeneizado, transferido para um eppendorf e centrifugado a 10.000 rpm durante 10 minutos a $4{ }^{\circ} \mathrm{C}$. O sobrenadante foi transferido para outro eppendorf, 
acondicionado em recipiente com gelo moído e, em seguida, realizou-se a determinação da atividade enzimática e a concentração de proteína, conforme descrito nos itens 3.3.4 e 3.3.5.

\subsubsection{Determinação da atividade da glutamina sintetase (GS; EC 6.3.1.2)}

A atividade da glutamina sintetase (GS) foi obtida pelo método proposto por Elliott (1953), o qual explora a atividade biossintética dessa enzima na formação de $\lambda$-glutamil hidroxamato.

A reação ocorreu sob agitação contínua em banho-maria a $30{ }^{\circ} \mathrm{C}$ em tubo de ensaio, no qual adicionou 0,5 mL de tampão TRIS-HCl $200 \mathrm{mM}, \mathrm{pH}$ 7,5; 0,2 mL de ATP $50 \mathrm{mM}, \mathrm{pH}$ 7,0; $0,5 \mathrm{~mL}$ de glutamato de sódio $500 \mathrm{mM} ; 0,1 \mathrm{~mL}^{\text {de }} \mathrm{MgSO}_{4}{ }^{-} ; 0,1 \mathrm{~mL}$ de cisteína $100 \mathrm{mM} ; 0,3 \mathrm{~mL}$ de hidroxilamina $100 \mathrm{mM}, \mathrm{pH}$ 7,0 e $0,3 \mathrm{~mL}$ de extrato, totalizando $2 \mathrm{~mL}$.

Após o período de incubação interrompeu-se a reação pela adição de $2,0 \mathrm{~mL}$ do reagente cloreto férrico $-\mathrm{FeCl}_{3} 123,2 \mathrm{mM}$, TCA $500 \mathrm{mM}, \mathrm{HCl}(6 \mathrm{~N}), 1: 1: 1$, onde se formou um complexo marrom amarelado como precipitado. Em seguida, a mistura foi centrifugada a $5.000 \mathrm{rpm}$, durante 5 minutos, e no material sobrenadante realizou-se a leitura colorimétrica para determinar a formação de $\lambda$-glutamil hidroxamato. A leitura foi realizada em espectrofotômetro a $540 \mathrm{~nm}$, e a atividade da enzima foi determinada a partir da comparação da leitura obtida com uma curva padrão, preparada previamente. Para o preparo da curva padrão, utilizou-se $\lambda$ - glutamil hidroxamato 15,42 $\mu \mathrm{M} / \mathrm{mL}$ - 0,010 g (PM 162,4 g) em $4 \mathrm{~mL}$ de água (Figura $11 \mathrm{~A}$ ).

Os resultados obtidos para GS foram expressos em $\mu$ moles $\lambda$-glutamil hidroxamato produzido por hora por miligrama de proteína ( $\mu \mathrm{M}$ de $\lambda-\mathrm{GH} \mathrm{h}^{-1} \mathrm{mg}^{-1}$ proteína).

\subsubsection{Determinação da concentração de proteína total solúvel (PTS)}

Para a determinação da concentração de proteína total solúvel (PTS) empregou-se metodologia descrita por Bradford (1976). A reação foi feita com $20 \mu \mathrm{L}$ do extrato preparado conforme o item 3.3.3 adicionados a 1,0 mL de reagente de Bradford e a leitura colorimétrica da reação, realizada em espectrofotômetro a $595 \mathrm{~nm}$.

A concentração de PTS das amostras foi calculada a partir da curva padrão preparada com albumina de soro bovino (BSA) (Figura 11 B). Os resultados obtidos foram expressos em $\mathrm{mg} \mathrm{g}^{-1}$ de matéria fresca (MF) e utilizados para os cálculos da atividade da GS. 

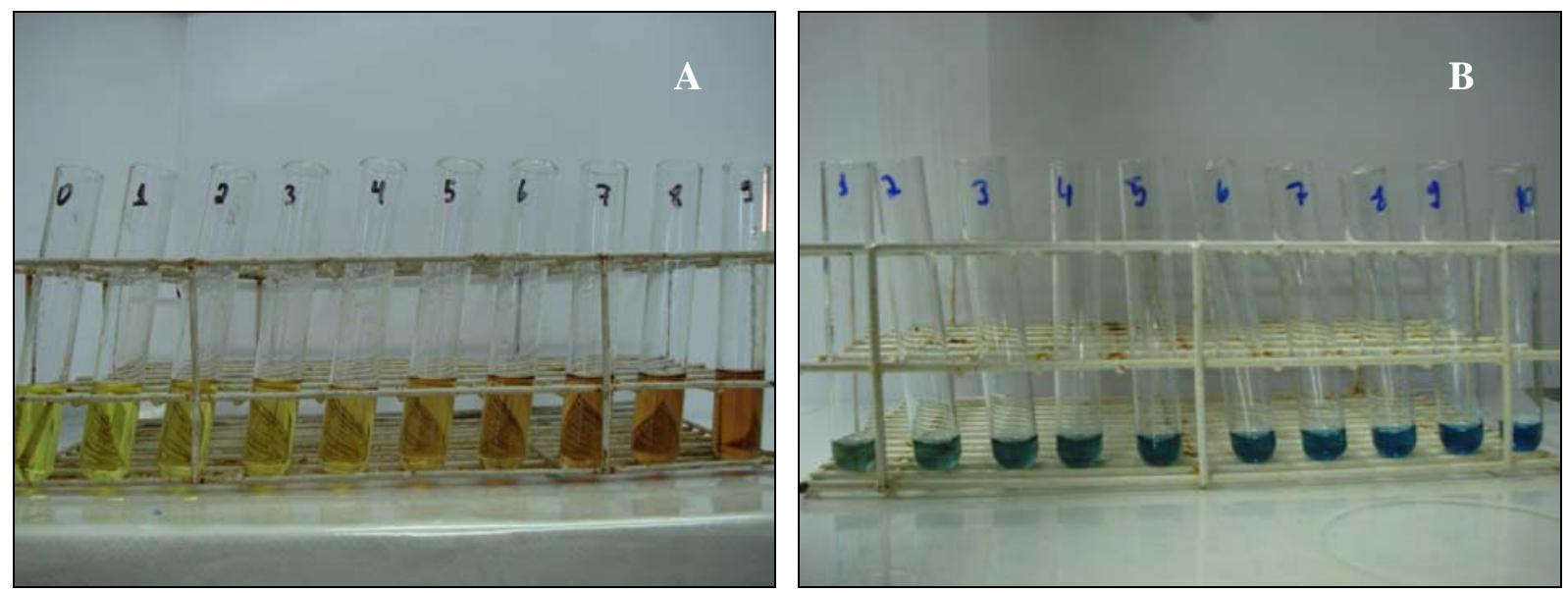

Figura 11 - Solução para obtenção da curva padrão de $\lambda$-glutamil hidroxamato para determinar a atividade de GS (A) e solução para obtenção da curva padrão de albumina de soro bovino (BSA) para quantificar a concentração de proteína total solúvel (B)

\subsubsection{Extração e quantificação de aminoácidos totais solúveis (ATS)}

O procedimento para extração e quantificação de aminoácidos foi baseado na técnica de Bielesky e Turner (1986), com algumas modificações. Para tanto, usou-se 0,2 g de material vegetal liofilizado, macerado em $2 \mathrm{~mL}$ da solução de extração MCW (12 mL de metanol, $5 \mathrm{~mL}$ de clorofórmio e $3 \mathrm{~mL}$ de água). Após overnight, a mistura foi centrifugada a $10.000 \mathrm{rpm}$ por 20 minutos a $4{ }^{\circ} \mathrm{C}$ e o sobrenadante misturado a $0,5 \mathrm{~mL}$ de clorofórmio e $0,75 \mathrm{~mL}$ de água. Da fase hidrossolúvel coletada, retirou-se uma alíquota para diluição com volume final de 1,0 mL (completado com água).

Para a quantificação acrescentou-se na solução de aminoácidos, $500 \mu \mathrm{L}$ de tampão citrato $+200 \mu \mathrm{L}$ de ninidrina $+1,0 \mathrm{~mL}$ de solução de $\mathrm{KCN}$. A mistura foi aquecida a $100{ }^{\circ} \mathrm{C}$ por $20 \mathrm{~min}$ e, em seguida, resfriada em água corrente por 10 minutos. Posteriormente, adicionou 1,3 mL de etanol 60 \% na solução, e a leitura realizada em espectrofotômetro a $570 \mathrm{~nm}$. A concentração de aminoácidos foi estimada segundo a curva padrão de solução de Leucina e, os dados, obtidos expressos em $\mathrm{mg} \mathrm{g}^{-1} \mathrm{MS}$.

\subsubsection{Determinação da concentração de pigmentos}

\subsubsection{Determinação da quantidade de clorofila $a$, clorofila $b$, clorofila total}

A determinação da quantidade de clorofila baseou-se na metodologia modificada de Lee, Brammeier e Smith (1987) e Moran (1982). Para tanto, foram usados 10 discos foliares, os quais 
totalizaram aproximadamente $0,1 \mathrm{~g}$ de material vegetal fresco de cada amostra. Os discos foram incubados no escuro a temperatura ambiente em eppendorf com $1,0 \mathrm{~mL}$ de $\mathrm{N}, \mathrm{N}-$ Dimetilformamida, durante 72 horas. Após este período os pigmentos diluídos na solução foram obtidos em espectrofotômetro a 646,8 e 663,8 nm. Os valores de absorbância foram aplicados nas eqs. (1) e (2) para determinação da quantidade de clorofila $a$, clorofila $b$ e clorofila total de cada amostra. A quantidade de pigmento foi expressa em $\mu \mathrm{g} \mathrm{mL} \mathrm{L}^{-1}$.

$$
\begin{gathered}
\text { Clorofila } a=12 \text { x ABS 663,8 }-3,11 \times \text { ABS 646,8 } \\
\text { Clorofila } b=20,78 \times \text { ABS 646,8 }-4,88 \text { x ABS 663,8 } \\
\text { Clorofila Total = Clorofila } a+b
\end{gathered}
$$

\subsubsection{Determinação da quantidade de carotenóides}

Para determinação da quantidade de carotenóides foram realizados os mesmos procedimentos adotados na determinação da clorofila com exceção do comprimento de onda para leitura no espectrofotômetro, que neste caso foi $480 \mathrm{~nm}$. Para determinar a quantidade de carotenóides utilizou-se a eq. (3) e o resultado obtido, expresso em $\mu \mathrm{g} \mathrm{mL} \mathrm{m}^{-1}$.

$$
\text { Carotenóides }=1.000 \times \text { ABS } 480-1,12 \times \text { Chlor } a-34,07 \times \text { Chlor } b / 245
$$

\subsubsection{Determinação das concentrações de $\mathbf{N}$-total, $\mathbf{N}$-nitrato e $\mathbf{N}$-amoniacal}

As concentrações de N-total, $\mathrm{N}_{-} \mathrm{NO}_{3}{ }^{-}$e $\mathrm{N}_{-} \mathrm{NH}_{4}{ }^{+}$foram determinados para auxiliar na compreensão dos resultados bioquímicos, em particular das atividades das enzimas RN, GS e urease.

Para determinação da concentração de N-total, o material vegetal liofilizado, obtido conforme item 3.2, foi submetido à digestão sulfúrica (JACKSON, 1958), e determinado de acordo com o método analítico semi-micro Kjeldahl (BREMNER, 1965) (Figura 12).

Para determinação das concentrações de amônio e nitrato nos tecidos utilizou-se a metodologia relatada por Tedesco, Volkweiss e Bohnen (1985), em que se utiliza a extração por $\mathrm{KCl} 1 \mathrm{M}$. As determinações de amônio e nitrato extraídos foram feitos por destilação a vapor (BREMNER; EDWARDS, 1965), com o destilador modificado conforme descrito por Tedesco e Gianello (1979). 

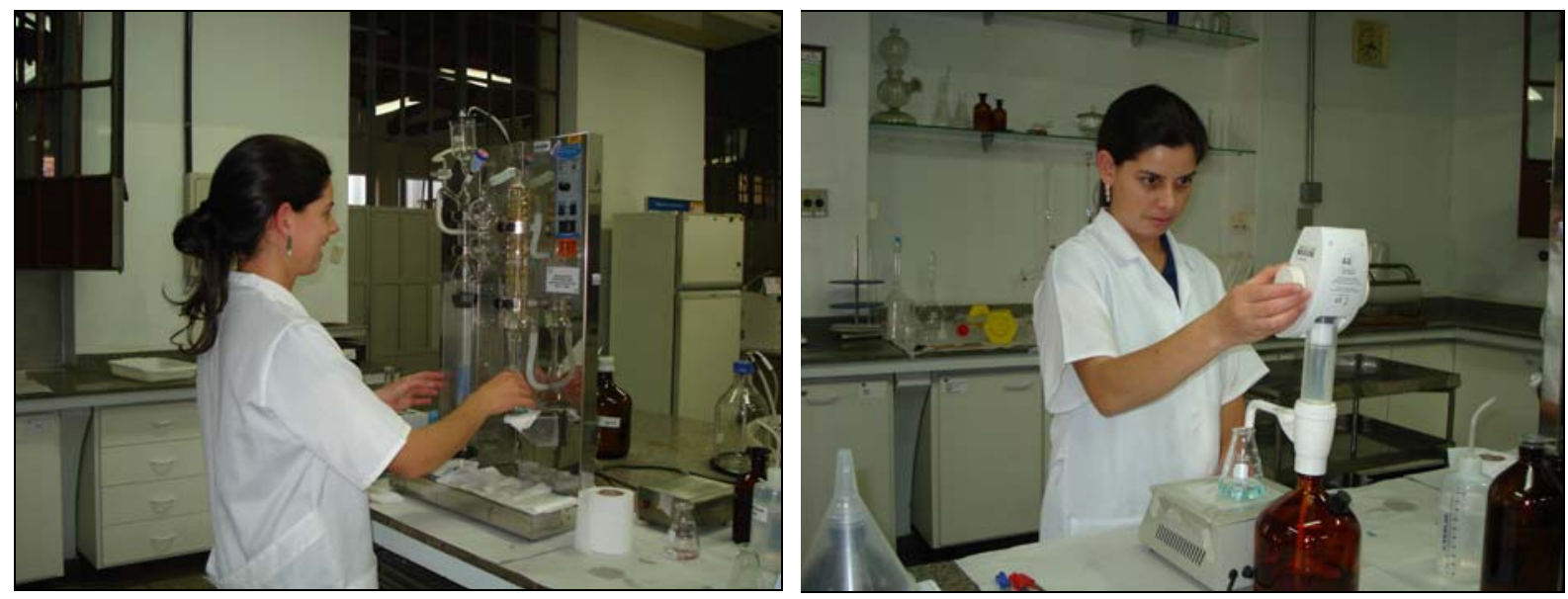

Figura 12 - Determinação de N total pelo método Kjeldahl

\subsubsection{Determinação das concentrações foliares dos demais nutrientes}

Para determinação das concentrações foliares de P, K, Ca, Mg, S, Fe, Mn, Zn e Cu o material vegetal liofilizado foi submetido à digestão nitroperclórica (JOHNSON; ULRICH, 1959). O Fósforo foi determinado por métodos analíticos de colorimetria do metavanadato; o potássio por fotometria de emissão de chama; o $\mathrm{Ca}, \mathrm{Mg}, \mathrm{Fe}, \mathrm{Mn}, \mathrm{Zn}$ e $\mathrm{Cu}$ quantificados por espectrofotometria de absorção atômica (Association - AOAC, 1975) e o S por turbidimetria do sulfato de bário (JACKSON, 1958). O B foi analisado após digestão das amostras por via seca (calcinação em mufla a $550{ }^{\circ} \mathrm{C}$ ) e determinado por colorimetria pelo método da Azometrina-H (BINGHAM, 1982).

\subsubsection{Parâmetros Fisiológicos}

As medidas de condutância estomática da planta foram realizadas em duas épocas na fase de granação, usando um medidor portátil de fotossíntese (LC pro+, ADC bioscientific Ltda) (Figura 13 A). As medições foram feitas para verificar a flutuação dessa variável durante o dia. Entretanto, só foi possível fazê-la em uma fase, devido à dependência do empréstimo do equipamento. 

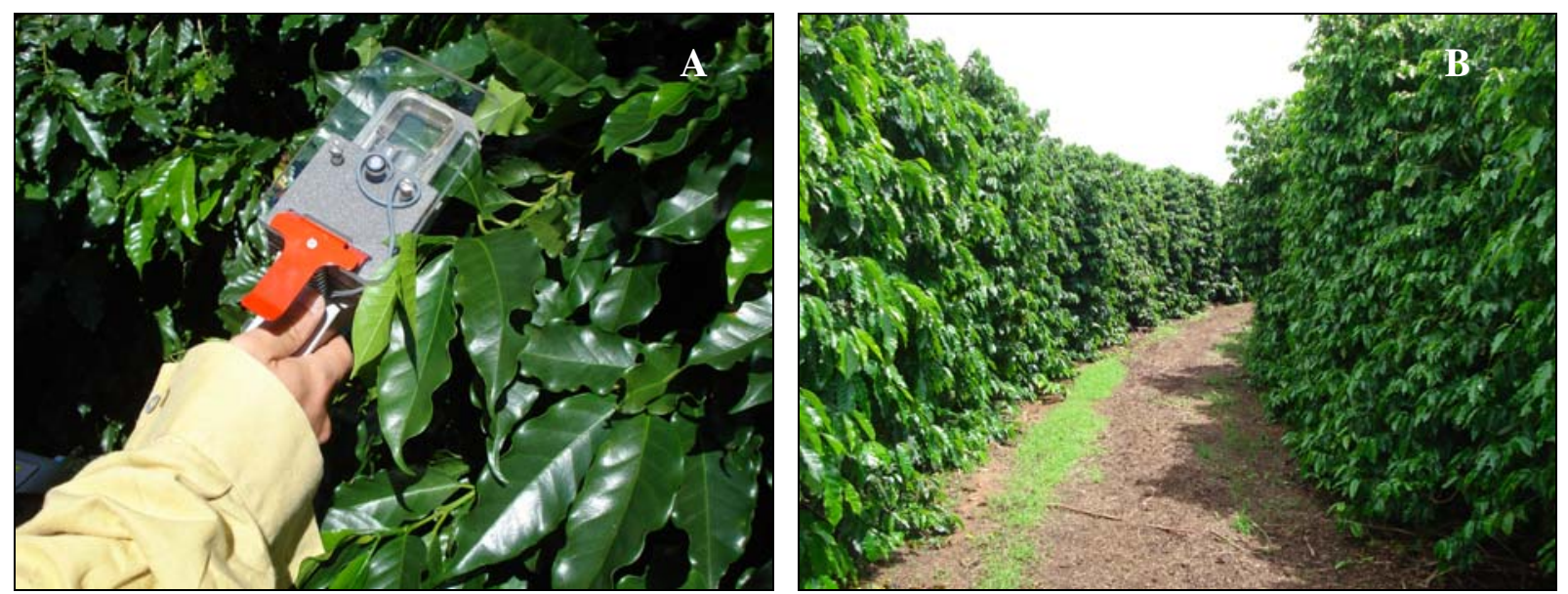

Figura 13 - Medidor portátil da condutância estomática (A) e plantas da área experimental (B)

\subsection{Análises estatísticas}

O experimento foi instalado em delineamento inteiramente casualisado, no esquema de parcelas subdivididas no tempo.

Os dados foram submetidos às análises estatísticas utilizando o programa estatístico SAS - System for Windows 9.1 (SAS INSTITUTE). Foram realizadas análises de regressão para ajustar modelos matemáticos que expliquem o comportamento dos dados. 


\section{RESULTADOS E DISCUSSÃO}

\subsection{Características do solo e clima do Oeste baiano}

O solo da área experimental é considerado de textura média (Tabela 2). Na implantação do experimento, em agosto, o solo apresentava, na camada de 0 a $20 \mathrm{~cm}: 25 \mathrm{~g} \mathrm{dm}^{-3}$ de matéria orgânica; pH ácido $(4,7)$; teor muito alto de $\mathrm{P}\left(114 \mathrm{mg} \mathrm{dm}^{-3}\right)$; médio de $\mathrm{K}\left(2 \mathrm{mmol}_{\mathrm{c}} \mathrm{dm}^{-3}\right)$; $\mathrm{Al}^{3+}$ igual a $3 \mathrm{mmol}_{\mathrm{c}} \mathrm{dm}^{-3} ; 31 \mathrm{mmol}_{\mathrm{c}} \mathrm{dm}^{-3}$ de acidez potencial $(\mathrm{H}+\mathrm{Al})$; e $8 \%$ de saturação por alumínio. O solo apresentava teores altos de $\mathrm{Ca}\left(23 \mathrm{mmol}_{\mathrm{c}} \mathrm{dm}^{-3}\right) ; \mathrm{Mg}\left(9 \mathrm{mmol}_{\mathrm{c}} \mathrm{dm}^{-3}\right)$ e $\mathrm{S}(10$ $\mathrm{mmol}_{\mathrm{c}} \mathrm{dm}^{-3}$ ) (RAIJ et al., 1996). Foram aplicados na área $3 \mathrm{t} \mathrm{ha}^{-1}$ de calcário, $400 \mathrm{~kg} \mathrm{ha}^{-1} \mathrm{de}$ gesso e $500 \mathrm{~kg} \mathrm{ha}^{-1}$ de $\mathrm{K}_{2} \mathrm{O}$ (Tabela 3). Além disso, forneceu 2,5 toneladas de esterco de galinha e 3 toneladas de casca de café.

O solo apresentava $1.080 \mathrm{mg} \mathrm{dm}^{-3}$ de $\mathrm{N}$ total, que equivale a $2.160 \mathrm{~kg} \mathrm{ha}^{-1}$ de $\mathrm{N}$ na camada de 0 a $20 \mathrm{~cm}$. No entanto, a maior parte (95\%) não está disponível às plantas porque encontra-se na forma orgânica $\left(\mathrm{R}-\mathrm{NH}_{2}\right)$. Para que seja absorvido pelas plantas e microrganismos, os compostos nitrogenados devem ser transformados em formas inorgânicas $\left(\mathrm{NH}_{4}{ }^{+}\right.$e $\left.\mathrm{NO}_{3}{ }^{-}\right)$pela oxidação microbiana, mediante a mineralização e nitrificação. O potencial de mineralização depende, além do conteúdo no solo, do ambiente e da natureza química da matéria orgânica (SIQUEIRA; FRANCO, 1988). Estudos indicam que 2 a $4 \%$ do N-orgânico total do solo é mineralizado por ano.

Quanto aos micronutrientes, o solo apresentava teores altos de B $\left(0,74 \mathrm{mg} \mathrm{dm}^{-3}\right), \mathrm{Cu}(9,6$ $\left.\mathrm{mg} \mathrm{dm}{ }^{-3}\right)$ e $\mathrm{Zn}\left(3,6 \mathrm{mg} \mathrm{dm}^{-3}\right)$ e médio de $\mathrm{Mn}$ (3,1 $\mathrm{mg} \mathrm{dm}^{-3}$ ) (Tabela 2). O cafezal foi, periodicamente, adubado com micronutrientes nas folhas para suprir as necessidades da planta (Tabela 3).

Os fatores climáticos, como a temperatura, precipitação, umidade do ar, luminosidade e fotoperíodo afetam significativamente o desenvolvimento e a produtividade das plantas (MORAES, 1963). Os cafeeiros são plantas perenifólias e formam folhas praticamente o ano todo, desde que haja disponibilidade de água e temperatura suficiente (CARR, 2001). O Oeste baiano apresenta características climáticas peculiares, diferentes das regiões tradicionais produtoras de café, como Minas Gerais e São Paulo. Na região o regime de chuvas é concentrado entre os meses de novembro e maio, como na safra 2008/2009, em que a precipitação foi, aproximadamente, $1.260 \mathrm{~mm}$ (Figura 5). O período de abril a outubro é marcado por seca, 
quando a irrigação é indispensável. No entanto, a irrigação é realizada também na época chuvosa, devido às condições favoráveis a transpiração, em solos com baixa capacidade de água disponível.

A disponibilidade hídrica além de atender a demanda transpiratória, influencia também as atividades metabólicas, como a termorregulação; manutenção da turgescência e da estrutura de moléculas; assim como o crescimento celular (MARENCO; LOPES, 2005). A água encontrada no xilema e floema funciona como meio de transporte de minerais e fotoassimilados. A turgescência é essencial para a expansão celular e crescimento (MARENCO; LOPES, 2005), em especial na fase de expansão rápida dos frutos (RAMIREZ et al., 2002), quando são elevadas as taxas de acúmulo de macro e micronutrientes nos frutos (LAVIOLA et al., 2007b).

Além das condições de solo e água, a temperatura influencia as atividades metabólicas das plantas. Tecidos em crescimento raramente sobrevivem à temperatura superior a $45^{\circ} \mathrm{C}$. Sob altas temperaturas a fotossíntese não consegue repor o carbono usado como substrato na respiração, com redução das reservas de carboidratos. Além disso, o aumento das temperaturas reduz a estabilidade das membranas e causa desnaturação de enzimas e proteínas.

$\mathrm{Na}$ área experimental a temperatura mínima foi igual a $9,9{ }^{\circ} \mathrm{C}$ no mês de julho/09 e a temperatura máxima $37^{\circ} \mathrm{C}$ no mês de outubro/08 (Figura 5). A temperatura média no período foi $23{ }^{\circ} \mathrm{C}$, considerada adequada para o desenvolvimento da cultura, pois segundo Rena e Maestri (1985), a temperatura ótima para assimilação de $\mathrm{CO}_{2}$ pelo cafeeiro varia entre 20 e $30^{\circ} \mathrm{C}$. Lima (2006) observou que a $24{ }^{\circ} \mathrm{C}$ ocorre a máxima taxa de fotossíntese e há decréscimo de $10 \%$ na taxa a cada aumento de $1{ }^{\circ} \mathrm{C}$ na temperatura. Com o aumento da temperatura, aumenta o transporte da solução do solo, com maior absorção e acúmulo de íons. Há também incremento do metabolismo nas raízes, aceleração da atividade respiratória da planta e maior produção de ATP, energia que será utilizada na absorção de íons (MARENCO; LOPES, 2005). No entanto, temperaturas superiores a $30^{\circ} \mathrm{C}$, por período prolongado, causam danos às folhas e abortamento dos botões florais (CAMARGO, 1985). Em contrapartida, em temperaturas menores a taxa de absorção dos minerais da solução do solo é reduzida, por diminuir a velocidade de transporte de nutrientes e fotoassimilados nos tecidos, bem como inibe as atividades que necessitam de energia metabólica (TAIZ; ZEIGER, 2004).

A luz é a fonte primária de energia dos seres fotossintetizantes (TAIZ; ZEIGER, 2004). A quantidade de luz e intensidade de brilho solar atua diretamente sobre a geração de energia para 
as células e influencia as respostas fisiológicas e bioquímicas das plantas. O Oeste baiano é marcado por maior quantidade de horas de brilho solar, comparativamente às regiões cafeeiras tradicionais. Isto acontece porque as chuvas são mais concentradas no ano e é menor a nebulosidade associada aos períodos chuvosos.

\subsection{Metabolismo do $\mathrm{N}$ - Oeste baiano}

Neste experimento houve interação significativa entre dose de $\mathrm{N}$ e fenologia do cafeeiro para as variáveis: $\mathrm{N}$ foliar, aminoácidos totais solúveis (ATS), nitrato, glutamina sintetase e urease (Tabelas 5).

As aplicações de $\mathrm{N}$ iniciaram em agosto, após a colheita, quando a planta apresentou a menor concentração do nutriente na fase vegetativa (VG) (Figura 14), o que pode ser atribuída à remobilização de compostos nitrogenados para os frutos colhidos anteriormente. $\mathrm{O}$ aumento na concentração foliar de $\mathrm{N}$ verificado na antese pode ser oriundo de compostos nitrogenados como aminoáciodos e reguladores de crescimento que se acumulam durante o outono/inverno nas raízes, caule e ramos, os quais se redistribuem para os drenos no início da primavera (AMARAL, 1991; DAMATTA; AMARAL; RENA, 1999). Ressalta-se também que na antese, observaram-se as maiores temperaturas (Figura 5), disponibilidade de água (irrigação e início das chuvas), o que favorece a absorção e o transporte do $\mathrm{N}$ para as folhas. Nesta fase foi observada a máxima concentração de $\mathrm{N}$ foliar, independentemente da dose de N (Figura 14).

A partir da fase de fruto chumbinho $(\mathrm{CH})$ observa-se redução na concentração de $\mathrm{N}$ foliar (Figura 14), devido à translocação do nutriente para o crescimento dos frutos nos estádios seguintes: expansão rápida (ER) e granação (GR). O maior requerimento de $\mathrm{N}$ por ocasião da formação dos grãos explica-se pela sua função como constituinte de aminoácidos e proteínas. Além da menor concentração foliar de $\mathrm{N}$ observada na fase vegetativa, constata-se que esta volta a ser reduzida após a fase de fruto chumbinho, atingindo concentrações mínimas na segunda avaliação da granação $\left(\mathrm{GR}_{2}\right)$, em conseqüência da intensa demanda por nutrientes e fotoassimilados, observada por Astolfi et al. (1981) e Rena, Barros e Maestri (2001). Esta observação pode ser feita, em particular, nessa safra (2008/2009) em que a produtividade variou entre 39 a 72 sacas ha $^{-1}$ (Figura 21). O aumento da concentração de $\mathrm{N}$ foliar a partir da granação até a maturação se deve a redução da demanda dos frutos, que nesta fase não é dreno intenso de $\mathrm{N}$. 
Em relação à dose de $\mathrm{N}$, as respostas significativas ocorreram nas fases de antese, granação e maturação (Figura 14). Nas fases de vegetação e chumbinho as maiores concentrações de $\mathrm{N}$ foliar foram obtidos com aplicação de 30,8 e $138,8 \mathrm{~kg} \mathrm{ha}^{-1}$, respectivamente, equivalente ao tratamento com $400 \mathrm{~kg} \mathrm{ha}^{-1}$, o que indica que a aplicação de doses de $\mathrm{N}$ superior a $400 \mathrm{~kg} \mathrm{ha}^{-1}$ não incrementa a concentração de $\mathrm{N}$ foliar e, portanto, seria desnecessária.

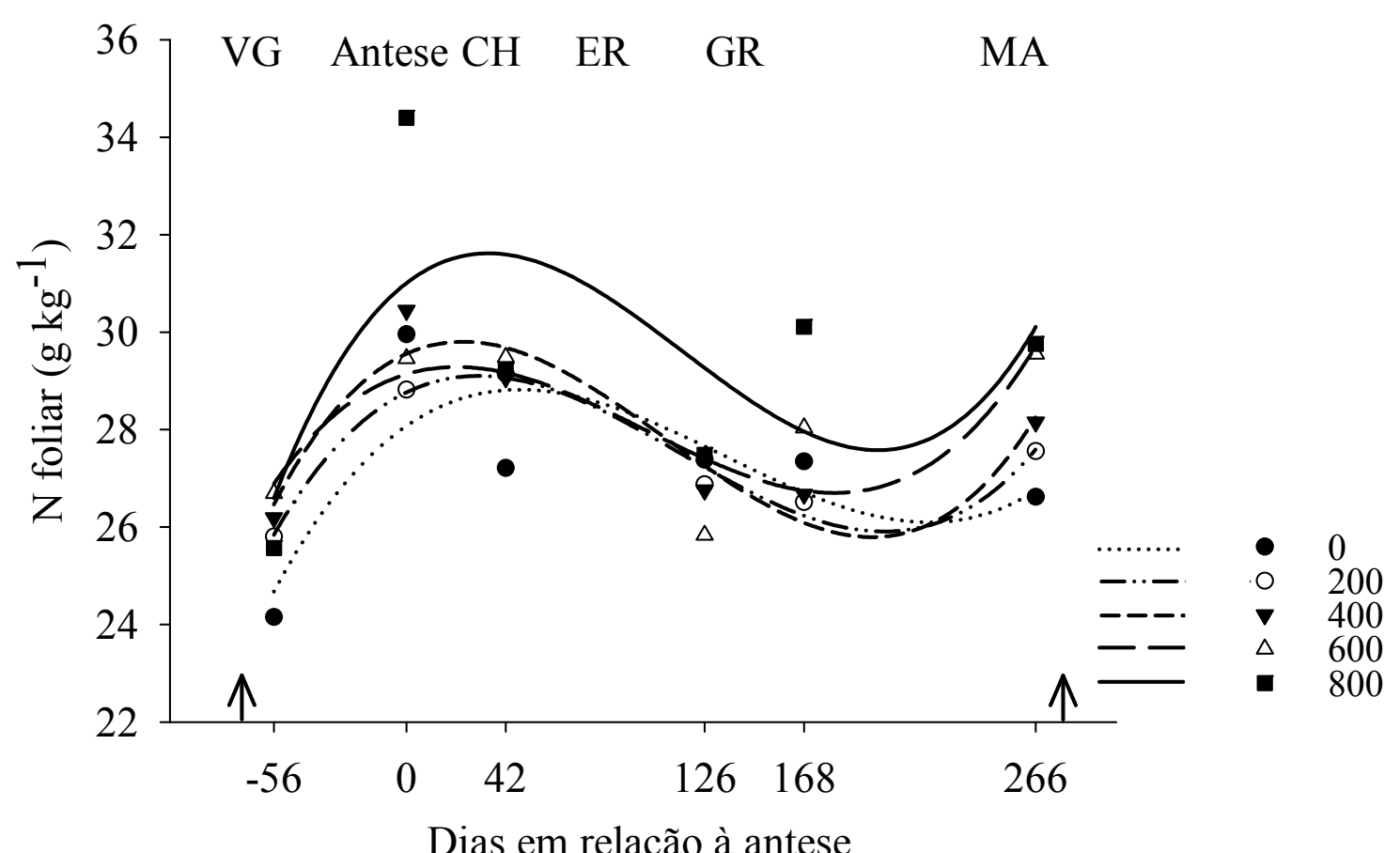

Figura 14 - Concentração de $\mathrm{N}$ em folhas de cafeeiro em função do tempo decorrido em relação a antese em cada dose de $\mathrm{N}\left(\mathrm{kg} \mathrm{ha}^{-1}\right)$ ( $\uparrow$ - início e fim da aplicação)

A menor significância da aplicação de diferentes doses de $\mathrm{N}$ na concentração de $\mathrm{N}$ foliar (Tabela 5) pode ser justificada pelo manejo do cafezal nos anos anteriores e pelo estado nutricional do cafeeiro antes da implantação do experimento, quando apresentava concentração de $\mathrm{N}$ entre 24 e $27 \mathrm{~g} \mathrm{~kg}^{-1}$ (Figura 14; VG). A área experimental recebeu aproximadamente $600 \mathrm{~kg}$ $\mathrm{ha}^{-1} \mathrm{ano}^{-1}$ de $\mathrm{N}$ nas safras anteriores à implantação do experimento, além de aplicações de fontes orgânicas (esterco de galinha e palha de café) (Tabela 3), cujo N pode ter sido disponibilizado durante a execução do experimento. As folhas apresentaram concentrações de $\mathrm{N}$ consideradas adequadas somente na antese e no período de fruto chumbinho (29 a $32 \mathrm{~g} \mathrm{~kg}^{-1}$ ) (MALAVOLTA; 
VITTI; OLIVEIRA, 1997). Nas demais fases, apesar das concentrações serem inferiores, não foram constatados sintomas visuais de deficiência de $\mathrm{N}$.

Tabela 5 - Resumo do nível de significância para os fatores dose, fenologia e para a interação dose vs fenologia

\begin{tabular}{lccc}
\hline Variável & Dose & Fenologia & Interação Dose vs Fenologia \\
\hline $\mathrm{N}$ foliar & $0,0250^{*}$ & $<0,0001^{*}$ & $0,0446^{*}$ \\
$\mathrm{ATS}$ & $<0,0001^{*}$ & $<0,0001^{*}$ & $<0,0001^{*}$ \\
$\mathrm{NO}_{3}{ }^{-}$ & 0,4904 & $<0,0001^{*}$ & $<0,0001^{*}$ \\
$\mathrm{NH}_{4}{ }^{+}$ & 0,1414 & $<0,0001^{*}$ & 0,2248 \\
$\mathrm{GS}$ & 0,1007 & $<0,0001^{*}$ & $0,0017^{*}$ \\
Urease & 0,7524 & $<0,0001^{*}$ & $<0,0001^{*}$ \\
Carotenóides & 0,8355 & $<0,0001^{*}$ & 0,7879 \\
Clorofila $a$ & 0,1138 & $<0,0001^{*}$ & 0,7664 \\
Clorofila $b$ & 0,2568 & $<0,0001^{*}$ & 0,7561 \\
Clorofila total & 0,1161 & $<0,0001^{*}$ & 0,7867 \\
Produção & $0,0656 \Delta$ & \\
\hline * significativo ao nível de 5\% de probabilidade $(\mathrm{p}<0,05)$ e $\Delta$ significativo ao nível de $10 \%$ de probabilidade \\
(p<0,05)
\end{tabular}

Tabela 6 - Médias das variáveis em razão das fases fenológicas

\begin{tabular}{lcccccc}
\hline Variáveis & $\mathrm{VG}$ & Antese & $\mathrm{CH}$ & $\mathrm{GR}_{1}$ & $\mathrm{GR}_{2}$ & $\mathrm{MA}$ \\
\hline $\mathrm{N}$ foliar & $25,7 \mathrm{~d}$ & $30,6 \mathrm{a}$ & $28,8 \mathrm{~b}$ & $26,9 \mathrm{~cd}$ & $27,7 \mathrm{bc}$ & $28,3 \mathrm{bc}$ \\
$\mathrm{ATS}$ & $1,008 \mathrm{c}$ & $1,417 \mathrm{a}$ & $1,511 \mathrm{a}$ & $1,089 \mathrm{bc}$ & $1,205 \mathrm{~b}$ & $1,096 \mathrm{bc}$ \\
$\mathrm{NO}_{3}^{-}$ & $66,7 \mathrm{c}$ & $108,8 \mathrm{ab}$ & $125,6 \mathrm{a}$ & $109,3 \mathrm{ab}$ & $118,5 \mathrm{ab}$ & $93,7 \mathrm{bc}$ \\
$\mathrm{NH}_{4}^{+}$ & $56,0 \mathrm{~cd}$ & $57,4 \mathrm{~cd}$ & $93,4 \mathrm{~b}$ & $66,4 \mathrm{c}$ & $114,6 \mathrm{a}$ & $42,8 \mathrm{~b}$ \\
$\mathrm{RN}$ & $0,523 \mathrm{a}$ & $0,286 \mathrm{c}$ & $0,255 \mathrm{c}$ & $0,398 \mathrm{~b}$ & $0,241 \mathrm{c}$ & $0,255 \mathrm{c}$ \\
$\mathrm{GS}$ & - & $55,8 \mathrm{~b}$ & $54,7 \mathrm{~b}$ & $143,1 \mathrm{a}$ & $68,6 \mathrm{~b}$ & $74,2 \mathrm{~b}$ \\
Urease & $3,7 \mathrm{~b}$ & $2,5 \mathrm{c}$ & $1,9 \mathrm{c}$ & $4,8 \mathrm{ab}$ & $5,2 \mathrm{a}$ & - \\
Carotenóides & $2,31 \mathrm{~b}$ & $1,88 \mathrm{c}$ & $1,93 \mathrm{c}$ & $2,19 \mathrm{~b}$ & $2,63 \mathrm{~b}$ & $2,64 \mathrm{a}$ \\
Clorofila $a$ & $10,29 \mathrm{a}$ & $8,63 \mathrm{~b}$ & $8,94 \mathrm{~b}$ & $9,4 \mathrm{ab}$ & $10,5 \mathrm{a}$ & $9,52 \mathrm{ab}$ \\
Clorofila $b$ & $3,38 \mathrm{~b}$ & $2,95 \mathrm{c}$ & $2,81 \mathrm{c}$ & $2,82 \mathrm{c}$ & $3,78 \mathrm{a}$ & $3,42 \mathrm{~b}$ \\
Clorofila total & $13,68 \mathrm{a}$ & $11,57 \mathrm{~b}$ & $11,74 \mathrm{~b}$ & $12,22 \mathrm{~b}$ & $14,29 \mathrm{a}$ & $12,94 \mathrm{ab}$ \\
\hline
\end{tabular}

* as médias seguidas pela mesma letra na horizontal não diferem entre si a $5 \%$ de probabilidade

A concentração foliar de aminoácidos seguiu o mesmo padrão da concentração de $\mathrm{N}$ foliar, com variação nas fases fenológicas da planta (Tabela 6) o que indica que parte do $\mathrm{N}$ armazenado nas folhas ocorre nesta forma. A maior concentração de aminoácidos nas folhas ocorreu na antese e as menores concentrações no período entre a $\mathrm{GR}_{2}$ e a maturação dos frutos (Figura 15) quando, provavelmente, foram realocados para o crescimento e formação dos grãos. 
As folhas velhas e as senescentes hidrolisam grande parte de suas proteínas e degradam outros compostos nitrogenados para o desenvolvimento de frutos e sementes, os quais recebem a maior parte do $\mathrm{N}$ na forma de aminoácidos, translocados pelo floema (MOROT-GAUDRY; JOB; LEA, 2001), razão da redução na concentração de aminoácidos foliares nas fases finais de desenvolvimento do fruto, constatados na presente pesquisa. Ressalta-se que a aplicação de 400, 600 e $800 \mathrm{~kg} \mathrm{ha}^{-1}$ de N, integralmente aplicadas na fase de maturação, aumentou a concentração de aminoácidos nesta fase, o que não aconteceu quando o $\mathrm{N}$ não foi aplicado ou pela aplicação de $200 \mathrm{~kg} \mathrm{ha}^{-1}$, em que foram observadas as menores concentrações de aminoácidos, com valores próximos a $0,67 \mathrm{mg} \mathrm{g}^{-1} \mathrm{MS}$ na maturação (Figura 15).

A dose de $\mathrm{N}$ aumentou a concentração de aminoácidos nas folhas em todas as fases de frutificação (Figura 15; Tabela 5). $\mathrm{O}$ aumento da concentração de $\mathrm{N}$ e aminoácidos com o aumento da dose de $\mathrm{N}$ aumentou na produtividade, somente até a aplicação de $400 \mathrm{~kg} \mathrm{ha}^{-1} \mathrm{de} \mathrm{N}$ (Figura 21).

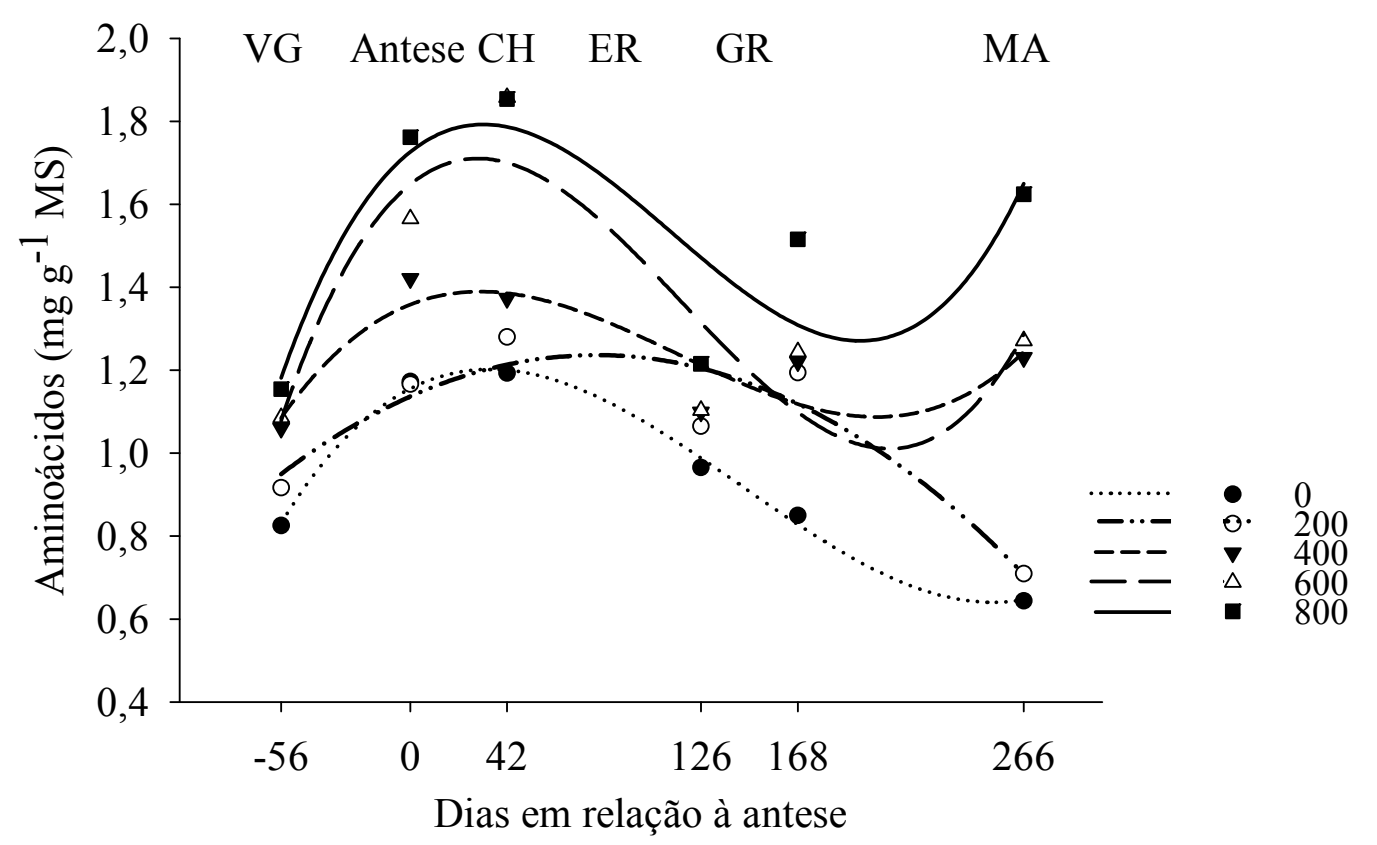

Figura 15 - Concentração de aminoácidos em folhas de cafeeiro em função do tempo decorrido em relação à antese em cada dose de $\mathrm{N}\left(\mathrm{kg} \mathrm{ha}^{-1}\right)$

As plantas apresentaram variação na concentração de nitrato e amônio nas fases fenológicas avaliadas (Figura 16 A, Tabela 6). As maiores concentrações de nitrato ocorreram entre as fases de chumbinho e granação $\left(\mathrm{GR}_{2}\right)$. A concentração de nitrato é crescente até a 
primeira avaliação na granação $\left(\mathrm{GR}_{1}\right)$, com concentração foliar máxima aos 126 dias após a antese, quando também constatou um pico na atividade da RN (Figura 17 B), o que se explica pelo fato do nitrato ser substrato para a referida enzima. A atividade da $\mathrm{RN}$ leva a formação de nitrito que é convertido rapidamente a amônio, como constatado na figura $16 \mathrm{~B}$, em que se observou que a maior concentração de amônio na granação $\left(\mathrm{GR}_{2}\right)$ se dá logo após a fase em que houve maior acúmulo de $\mathrm{NO}_{3}{ }^{-}$e do pico da atividade de $\mathrm{RN}$ também na granação $\left(\mathrm{GR}_{1}\right)$.

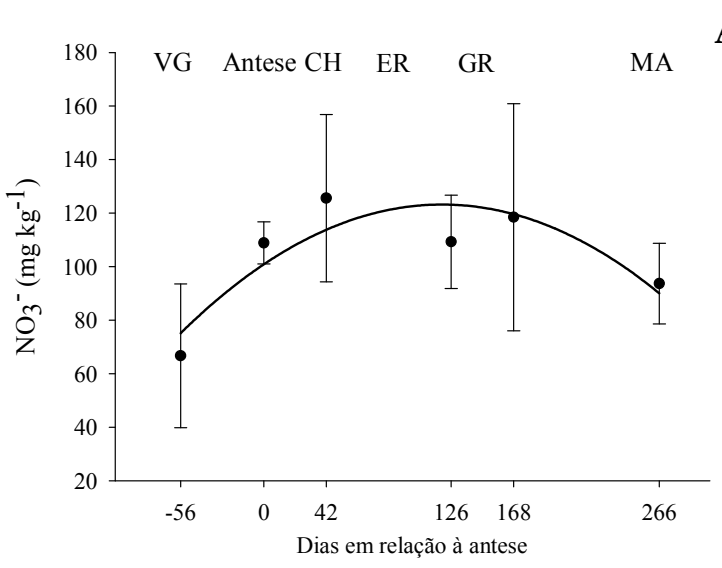

A

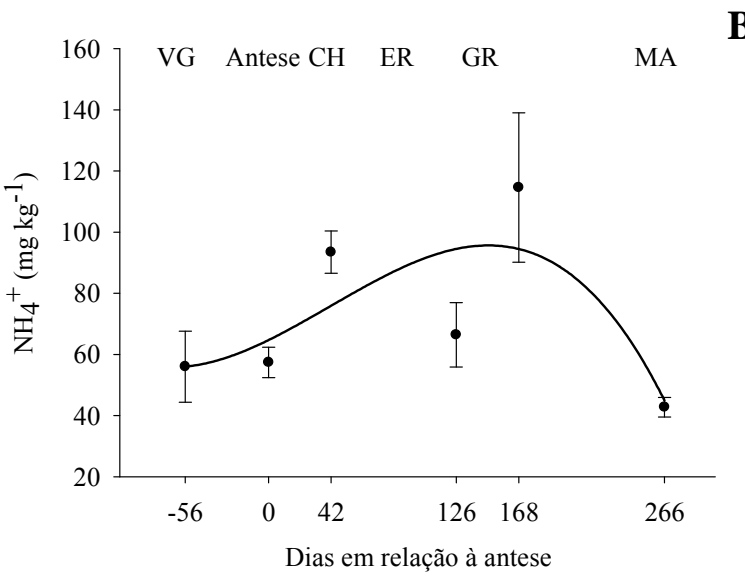

Figura 16 - Concentração de $\mathrm{NO}_{3}^{-}$(A) e $\mathrm{NH}_{4}^{+}$(B) em folhas de cafeeiro em função da fenologia da planta

Nas fases fenológicas houve variação da atividade da $\mathrm{RN}$ em razão da hora de avaliação (Tabela 6; 7). As maiores atividades da enzima foram obtidas às $12: 00 \mathrm{~h}\left(0,44 \mu \mathrm{mol} \mathrm{NO}{ }_{2}^{-} \mathrm{h}^{-1} \mathrm{~g}^{-1}\right.$ $\mathrm{MF})$, seguida pelas médias obtidas às 7:00 $\mathrm{h}\left(0,33 \mu \mathrm{mol} \mathrm{NO}{ }_{2}^{-} \mathrm{h}^{-1} \mathrm{~g}^{-1} \mathrm{MF}\right)$, as quais diferiram da avaliação às 17:00 $\mathrm{h}\left(0,25 \mu \mathrm{mol} \mathrm{NO}{ }_{2}^{-} \mathrm{h}^{-1} \mathrm{~g}^{-1} \mathrm{MF}\right)$ e às 22:00 $\mathrm{h}\left(0,22 \mu \mathrm{mol} \mathrm{NO}{ }_{2}^{-} \mathrm{h}^{-1} \mathrm{~g}^{-1} \mathrm{MF}\right)$, que não diferiram entre si (Figura 17 A). Portanto, pode-se dizer que a intensidade de luz e a temperatura ao meio-dia aumentaram a atividade da enzima, que é ativada pela luz, além de carboidratos e outros fatores ambientais, que estimulam a fosfatase, que desfosforila resíduos de serina na RN e promovem sua ativação (TAIZ; ZEIGER, 2004; KAISER et al, 2002). Estes dados não corroboram os dados obtidos por Netto (2005), que trabalhou com mudas de cafeeiro, o qual obteve maior atividade da enzima RN às 22:00 h. Carelli, Fahl e Magalhães (1990) e Queiroz et al. (1993) também obtiveram maior atividade da enzima no período noturno. Ressaltase que estas pesquisas foram realizadas com mudas e tais dados foram utilizados para afirmar que o cafeeiro difere da maioria das plantas. No entanto, pelos dados obtidos na presente pesquisa, verifica-se que o cafeeiro adulto comporta-se como a maioria das plantas, ou seja, a atividade da 
RN é superior na luz (12:00 h). Observa-se ainda que a maior atividade da enzima RN foi obtida com a aplicação de $800 \mathrm{~kg} \mathrm{ha}^{-1}$ e não houve variação significativa nas demais doses (Figura 17 A).

Tabela 7 - Resumo do nível de significância para os fatores dose, hora, interação dose vs hora, fenologia, interação fenologia vs hora e interação fenologia vs hora vs dose para a enzima redutase do nitrato $(\mathrm{RN})$

\begin{tabular}{lllc}
\hline Dose & $0,0110^{*}$ & Interação Hora $v s$ Dose & 0,1265 \\
Hora & $<0,0001^{*}$ & Interação Hora vs Fenologia & $<0,0001^{*}$ \\
Fenologia & $<0,0001^{*}$ & Interação Dose vs Fenologia & 0,2320 \\
- & - & Interação Fenologia vs Hora vs Dose & 0,2179 \\
\hline
\end{tabular}

* significativo ao nível de $5 \%$ de probabilidade $(\mathrm{p}<0,05)$

A maior atividade da enzima RN foi obtida na fase de vegetação $\left(0,52 \mu \mathrm{mol} \mathrm{NO}_{2}^{-} \mathrm{h}^{-1} \mathrm{~g}^{-1}\right.$ MF) (Figura 17 B; Tabela 6), logo após as duas primeiras fertilizações com $\mathrm{N}$ iniciadas em agosto (VG), quando foi observado a menor concentração de $\mathrm{N}$ foliar $\left(25,7 \mathrm{~g} \mathrm{~kg}^{-1}\right)$.A elevada atividade da enzima nessa época pode ser explicada pela assimilação do $\mathrm{NO}_{3}{ }^{-}$armazenado nas raízes, caules e ramos ou absorvidos diretamente do solo com as primeiras aplicações, já que a concentração de nitrato nas folhas na fase VG foi a menor $\left(66,7 \mathrm{mg} \mathrm{kg}^{-1}\right)$ em relação as demais fases fenológicas. A absorção de nitrato é mais intensa antes da floração e no início da maturação dos frutos (CARVAJAL; ACEVEDO; LOPEZ, 1969). Na fase anterior a antese há uma intensa demanda de nutrientes para o desenvolvimento dos botões florais, o que exige rápido transporte de metabólitos, como compostos nitrogenados, das folhas mais próximas e fotossinteticamente ativas, o que explicaria, em parte, a superioridade da atividade da $\mathrm{RN}$ na fase vegetativa (Figura 17 B).

A redução da atividade da $\mathrm{RN}$ na fase chumbinho não aconteceu por falta de substrato $\left(\mathrm{NO}_{3}{ }^{-}\right)$, cuja concentração foliar foi igual a $125,6 \mathrm{mg} \mathrm{kg}^{-1}$ (Figura $16 \mathrm{~A}$; Tabela 6). Além do pico na fase vegetativa, houve novo pico de atividade da enzima na $\mathrm{GR}_{1}$ aos $126 \mathrm{DRA}$, provavelmente para atender a demanda por novos aminoácidos, uma vez que a concentração destes compostos reduziu nesta fase fenológica. A verificação do pico de atividade da $\mathrm{RN}$ entre fruto chumbinho e a $\mathrm{GR}_{2}$, período de desenvolvimento dos frutos, corrobora os dados obtidos por Carelli, Fahl e Magalhães (1989). 
$\mathrm{Na}$ segunda avaliação da granação $\left(\mathrm{GR}_{2}-168 \mathrm{DRA}\right)$ a atividade da $\mathrm{RN}$ reduziu novamente (Figura 17 B). Esta observação pode ser explicada pelo acúmulo de amônio, que atingiu a maior concentração foliar nesta época $\left(114,6 \mathrm{mg} \mathrm{kg}^{-1}\right)$, e que pode ter inibido a atividade da RN.

Entre a $\mathrm{GR}_{2}$ e a maturação dos frutos, a atividade da $\mathrm{RN}$ foi a menor $\left(0,24 \mu \mathrm{mol} \mathrm{NO}_{2}{ }^{-} \mathrm{h}^{-1}\right.$ $\mathrm{g}^{-1}$ MF) e praticamente não variou no período, provavelmente para suprir a demanda de aminoácidos pelas folhas, como sugere o aumento do composto (Figura 15). Houve uma redução da concentração de amônio na fase de maturação dos frutos (Figura $16 \mathrm{C}$ ) que provavelmente foi convertido a aminoácidos (Figura 15). Esta afirmação é sustentada pelo aumento acentuado de aminoácidos, nas doses 400, 600 e $800 \mathrm{~kg} \mathrm{ha}^{-1}$ de $\mathrm{N}$, compostos nitrogenados resultantes da assimilação do amônio pela GS.

$\mathrm{O}$ aumento da atividade da RN apartir de outubro também foi observado por Freitas et al. (2007). Para estes autores, tal constatação se deu pela elevação da temperatura e em razão da manutenção da concentração de nitrato nas folhas. Na presente pesquisa, os dados obtidos corroboram o aumento da atividade da $\mathrm{RN}$ a partir de outubro, entre $\mathrm{CH}$ e $\mathrm{GR}_{1}$ (Figura $17 \mathrm{~B}$ ), assim como as suas causas: elevação da temperatura mínima $\left(18{ }^{\circ} \mathrm{C}\right)$ (Figura 5) e maior concentração de nitrato (Figura 16 A).
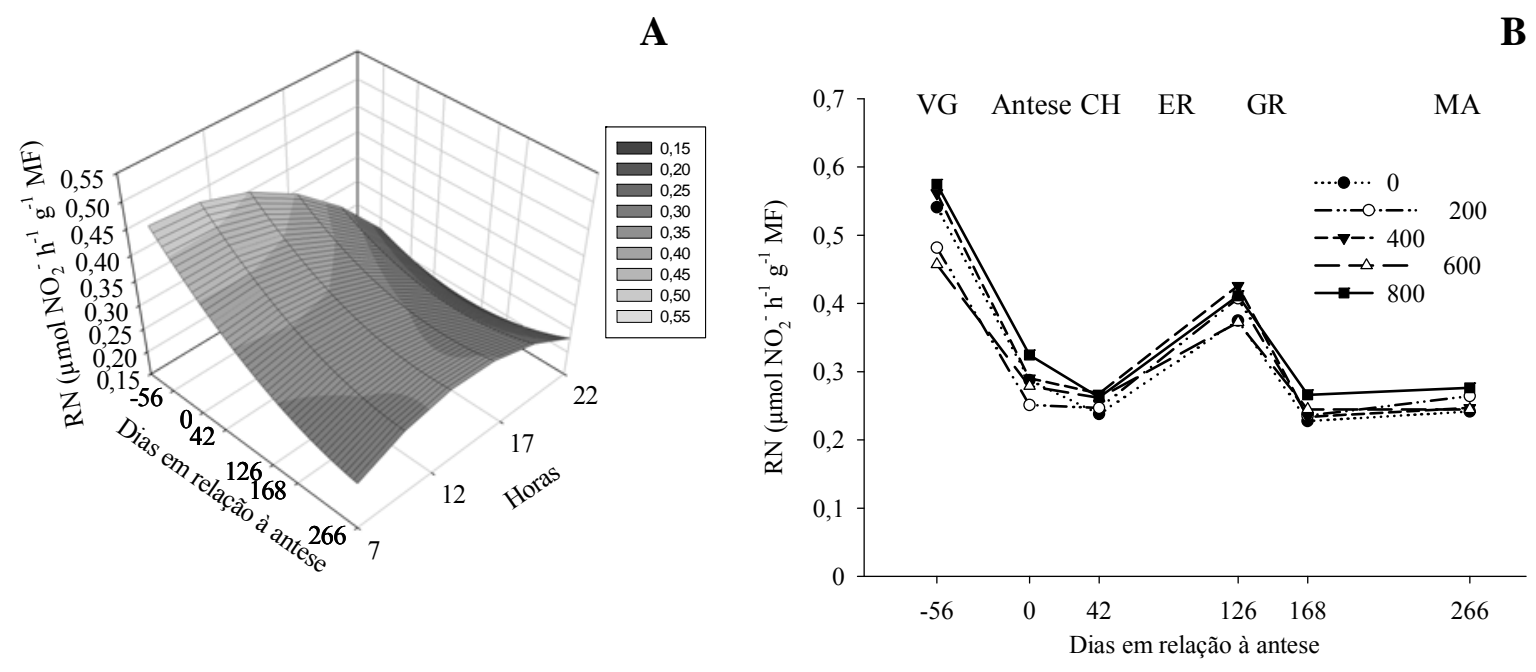

Figura 17 - Atividade da enzima redutase do nitrato em folhas de cafeeiro em função do tempo decorrido em relação à antese em 4 horas do dia (A) e em cada dose de $\mathrm{N}$ (B)

A atividade da glutamina sintetase (GS) apresentou interação significativa entre a dose de $\mathrm{N}$ e a fase fenológica (Tabela 5). As maiores atividades da GS foram obtidas na granação $\left(\mathrm{GR}_{1}\right)$ 
para todas as doses de N. Esta maior atividade pode ter sido estimulada pela concentração de amônio presente nas folhas nesta fase, conforme observado na figura 16 B. Este amônio pode se originar da fotorrespiração, da absorção do solo ou resultar da atividade da $\mathrm{RN}$, que foi maior na $\mathrm{GR}_{1}$ (Figuras $17 \mathrm{~B}$ ). Além disso, a maior atividade da $\mathrm{GS}$ na $\mathrm{GR}_{1}$ pode ser conseqüência da elevada atividade da urease (Figura 19), cujos produtos da ação desta enzima são o amônio e o $\mathrm{CO}_{2}$, conforme relatado por Dixon et al. (1975).

As menores atividades da GS na antese e a partir da granação (Figura 18) apresentam comportamento semelhante ao constatado para a atividade de $\mathrm{RN}$, quando também foram observadas atividades inferiores da enzima (Figura $17 \mathrm{~B}$ ). A queda na atividade a partir da granação $\left(\mathrm{GR}_{2}\right.$ e $\left.\mathrm{MA}\right)$ pode ser atribuída à redução na isoforma GS2, que como outras enzimas cloroplastídicas, sofre hidrólise preferencial durante essa fase (OAKS; HIREL, 1985 ). A atividade da GS aumentou no tratamento sem $\mathrm{N}$ a partir da granação $\left(\mathrm{GR}_{2}\right)$, observação sem significação biológica.

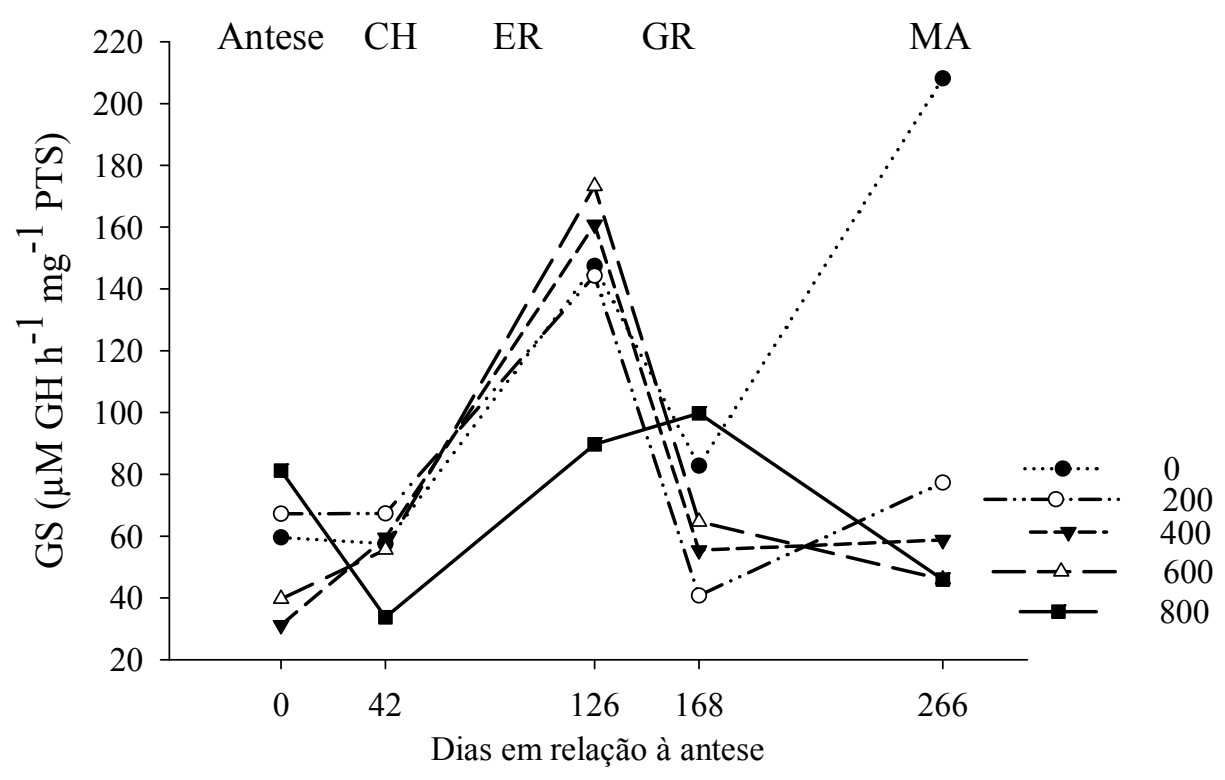

Figura 18 - Atividade da enzima glutamina sintetase em folhas de cafeeiro em função do tempo decorrido em relação à antese em cada dose de $\mathrm{N}$

Para a atividade da enzima urease houve interação significativa entre a dose de $\mathrm{N}$ e a fase fenológica do cafeeiro (Tabelas 5). 
A maior atividade de urease foi observada nas fases de granação $\left(\mathrm{GR}_{1}\right.$ e $\left.\mathrm{GR}_{2}\right)$ (Figura 19), quando observou maior concentração de amônio (Figura 16 B), que pode originar, entre outros processos, da atividade da urease, a qual catalisa a hidrólise da uréia para formar amônio e $\mathrm{CO}_{2}$ (DIXON et al., 1975). A absorção da uréia, associada ao seu acúmulo pelo catabolismo de ureídeos, alantoato, alantoina e arginina (Figura 3) estimula a ação da urease. A atividade desta enzima permite aos organismos a utilização da uréia absorvida ou gerada internamente como fonte de N (MOBLEY; ISLAND; HAUSINGER, 1995). O amônio gerado pela urease pode ser incorporado ao glutamato e formar glutamina, pela enzima GS (Figura 3), o que pode ser confirmado pela maior atividade de GS no mesmo período (granação) em que a atividade da urease foi superior. Não foi encontrado estudos da atividade de urease em cafeeiros.

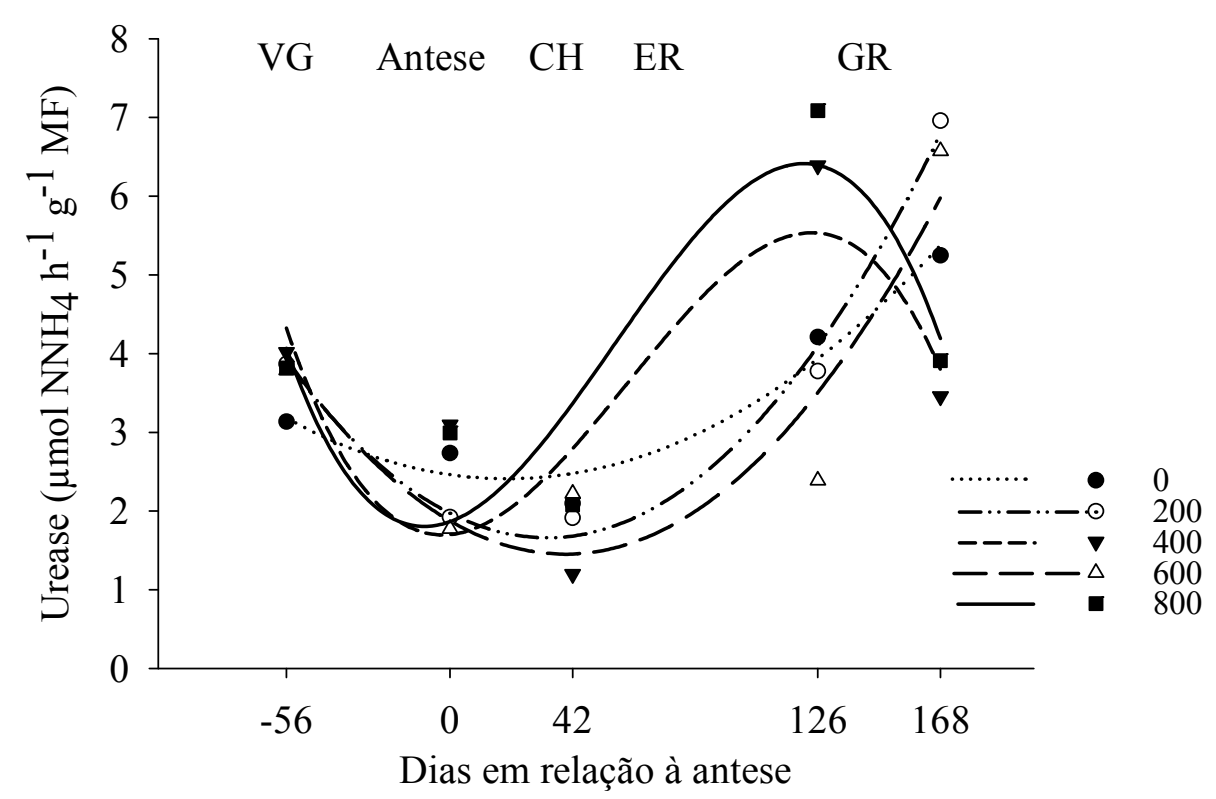

Figura 19 - Atividade da enzima urease em folhas de cafeeiro em função do tempo decorrido em relação à antese em cada dose de $\mathrm{N}$

A concentração de clorofila $a, b$ e total não respondeu às doses de $\mathrm{N}$, mas variou em relação às fases fenológicas (Tabela $5 ; 6$ ). A maior concentração de clorofila foi observada nas $\mathrm{GR}_{2}$ (Figura 20). Estes dados a princípio contrariam o esperado, pois a concentração de clorofila normalmente se correlaciona com a concentração de $\mathrm{N}$ foliar (REIS et al,, 2009), o que não foi constatado neste trabalho (Figura 14). A concentração reduzida de clorofila na fase de fruto chumbinho, quando verificou a maior concentração de $\mathrm{N}$ foliar, pode ser explicada, em parte, 
pela concentração limitante de $\mathrm{Mg}$ nas folhas, uma vez que o valor médio deste nutriente foi 2,8 $\mathrm{g}$ $\mathrm{kg}^{-1}$ (Figura 30), concentração considerada inferior à adequada (4 a 4,5 $\mathrm{g} \mathrm{kg}^{-1}$ ) (MALAVOLTA; VITTI; OLIVEIRA, 1997). A clorofila tem uma complexa estrutura em anel tipo porfirina com um átomo de $\mathrm{Mg}$ coordenado no centro de 4 átomos de $\mathrm{N}$.

A concentração de carotenóides seguiu o mesmo padrão da concentração de clorofila, com diferenças significativas somente nas fases fenológicas, verificando maior concentração no final de frutificação (Figura 20).

Vale ressaltar que as plantas não apresentaram sintomas visuais de deficiências de $\mathrm{N}$ em nenhuma das fases fenológicas durante a pesquisa.
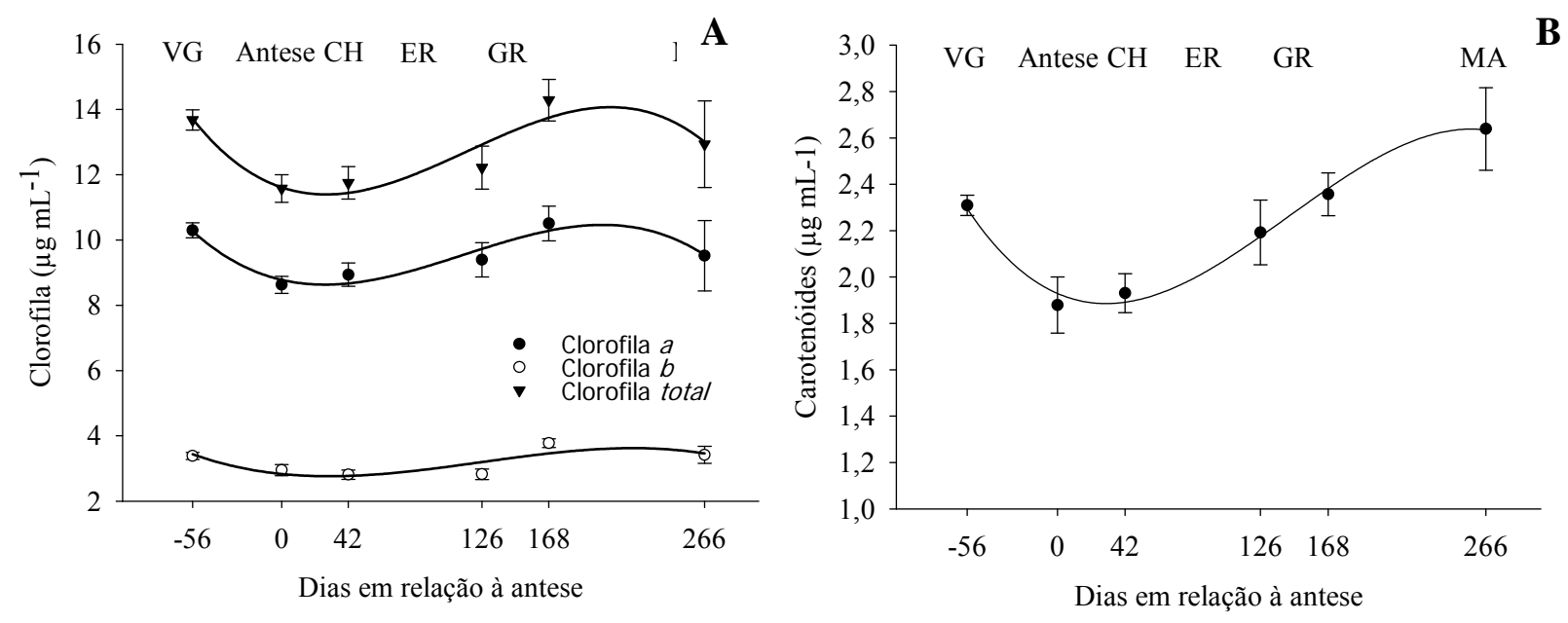

Figura 20 - Concentração de clorofila a, b e total (A), concentração de carotenóides (B) em folhas de cafeeiro em função do tempo decorrido em relação à antese

Na tabela 8 são apresentadas as equações de regressão para as variáveis relacionadas ao metabolismo do N. Para cada uma das doses foram ajustados modelos matematicos. 
Tabela 8 - Equações de regressão da variação nas concentrações de $\mathrm{N}, \mathrm{ATS}, \mathrm{PTS}, \mathrm{NO}_{3}{ }^{-}, \mathrm{NH}_{4}{ }^{+} \mathrm{e}$ Urease em folhas de cafeeiros em função do tempo decorrido em relação a antese (dias) em 5 doses de $\mathrm{N}$ aplicado $\left(\mathrm{kg} \mathrm{ha}^{-1}\right)$

\begin{tabular}{|c|c|c|c|}
\hline Variável & $\begin{array}{l}\text { Dose de N } \\
\left(\mathrm{kg} \mathrm{ha}^{-1}\right)\end{array}$ & Modelo & $\mathrm{R}^{2}$ \\
\hline \multirow{5}{*}{$\mathrm{N}$} & 0 & $\hat{y}=28,073+0,0335 x-0,000425 x^{2}+0,00000105 x^{3}$ & 0,600 \\
\hline & 200 & $\hat{y}=28,762+0,0234 x-0,000445 x^{2}+0,00000127 x^{3}$ & 0,975 \\
\hline & 400 & $\hat{y}=29,557+0,0217 x-0,000513 x^{2}+0,00000155 x^{3}$ & 0,865 \\
\hline & 600 & $\hat{y}=29,136+0,0146 x-0,000385 x^{2}+0,00000127 x^{3}$ & 0,661 \\
\hline & 800 & $\hat{y}=31,004+0,0375 x-0,000635 x^{2}+0,00000181 x^{3}$ & 0,405 \\
\hline \multirow{5}{*}{$\begin{array}{l}\text { Aminoáci- } \\
\text { do total } \\
\text { solúvel } \\
\text { (ATS) }\end{array}$} & 0 & $\hat{y}=1,15478+0,00283 x-0,0000466 x^{2}+0,000000108 x^{3}$ & 0,994 \\
\hline & 200 & $\hat{y}=1,136+0,00248 x-0,0000154 x^{2}$ & 0,857 \\
\hline & 400 & $\hat{y}=1,359+0,00218 x-0,0000415 x^{2}-0,000000119 x^{3}$ & 0,726 \\
\hline & 600 & $\hat{y}=1,648+0,00449 x-0,0000877 x^{2}+0,000000247 x^{3}$ & 0,782 \\
\hline & 800 & $\hat{y}=1,726+0,00443 x-0,0000812 x^{2}+0,000000239 x^{3}$ & 0,716 \\
\hline \multirow{5}{*}{$\begin{array}{l}\text { Proteína } \\
\text { total solúvel } \\
\text { (PTS) }\end{array}$} & 0 & $\hat{y}=3,238-0,0103 x+0,0000839 x^{2}+0,000000279 x^{3}$ & 0,955 \\
\hline & 200 & $\hat{y}=2,692-0,0147 x+0,000328 x^{2}-0,00000101 x^{3}$ & 0,897 \\
\hline & 400 & $\hat{y}=5,785-0,115 x+0,000981 x^{2}-0,00000217 x^{3}$ & 0,976 \\
\hline & 600 & $\hat{y}=5,290-0,0718 x+0,000531 x^{2}-0,00000101 x^{3}$ & 0,997 \\
\hline & 800 & $\hat{y}=2,635+0,0999 x-0,00103 x^{2}+0,00000256 x^{3}$ & 0,954 \\
\hline $\mathrm{NO}_{3}^{-}$ & & $\hat{y}=100,876+0,373 x-0,0016 x^{2}$ & 0,784 \\
\hline $\mathrm{NH}_{4}^{+}$ & & $\hat{y}=67,716+0,239 x+0,00100 x^{2}-0,00000827 x^{3}$ & 0,571 \\
\hline \multirow{5}{*}{ Urease } & 0 & $\hat{\mathrm{y}}=2,461-0,00529 \mathrm{x}+0,000135 \mathrm{x}^{2}$ & 0,949 \\
\hline & 200 & $\hat{y}=2,11609-0,199 x+0,000215 x^{2}+0,000000437 x^{3}$ & 0,989 \\
\hline & 400 & $\hat{y}=1,700+0,00367 x+0,000690 x^{2}-0,00000380 x^{3}$ & 0,611 \\
\hline & 600 & $\hat{y}=1,874-0,0215 x+0,000273 x^{2}$ & 0,854 \\
\hline & 800 & $\hat{y}=1,866+0,0134 x+0,000707 x^{2}-0,00000419 x^{3}$ & 0,751 \\
\hline
\end{tabular}

A produtividade variou com a dose de $\mathrm{N}$ a 10\% de probabilidade (Figura 21; Tabela 5). A utilização de maior nível de significância se deve as características fisiológicas do cafeeiro, sendo comum observar em campo plantas com baixa e alta produção, o que provoca altos coeficientes de variação. O cafeeiro completa seu ciclo reprodutivo em dois anos. No primeiro ano a planta apresenta maior taxa de crescimento vegetativo (crescimento dos ramos), enquanto no segundo ano o crescimento vegetativo é reduzido e destina os fotoassimilados e minerais à produção de flores e frutos, nos ramos crescidos no ano anterior. Assim, a adubação realizada num ano exerce grande influência na produção do ano seguinte.

Em cafeeiros, como na presente pesquisa, implantados em região com temperatura média de outono/inverno maior que $22{ }^{\circ} \mathrm{C}$, fertirrigado ao longo do ano e densidade superior a 5.000 plantas por hectare, a produtividade está relacionada com número de indivíduos por hectare, uma 
vez que a produção por planta é baixa, aproximadamente 5 litros por planta. Estas condições diferem das regiões cafeeiras tradicionais do Estado de Minas Gerais e São Paulo.

Do exposto, pode-se admitir que os cafeeiros do Oeste baiano, por produzirem menor quantidade de frutos por planta, vegetam o suficiente para produzirem bem anualmente, quando as condições ambientais forem favoráveis e houver suprimento adequado de nutrientes.

A elevada produtividade nas plantas sem fornecimento de $\mathrm{N}\left(39,4\right.$ sacas $\left.^{-1} \mathrm{a}^{-1}\right)$ (Figura 21) pode ser conseqüência das adubações de $600 \mathrm{~kg} \mathrm{ha}^{-1}$ nos anos anteriores a instalação da pesquisa, bem como pelo $\mathrm{N}$ fornecido pela mineralização de substâncias orgânicas naturais do solo (matéria orgânica não estabilizada e organismos), e também pelo $\mathrm{N}$ introduzido na área experimental na forma de esterco de galinha e palha de café.

A produtividade do cafeeiro respondeu a aplicação de $400 \mathrm{~kg} \mathrm{ha}^{-1}$ de $\mathrm{N}$, não diferindo do fornecimento de 600 e $800 \mathrm{~kg} \mathrm{ha}^{-1}$ (Figura 21), com risco de prejuízo às plantas pelo fornecimento de $800 \mathrm{~kg} \mathrm{ha}^{-1}$. Uma explicação à ausência de resposta as doses superiores a $400 \mathrm{~kg}$ $\mathrm{ha}^{-1}$ de $\mathrm{N}$, se deve a competição da assimilação de $\mathrm{N}$ com a fotossíntese, por carboidratos e energia, que pode ser entendida pela lei dos rendimentos decrescentes.

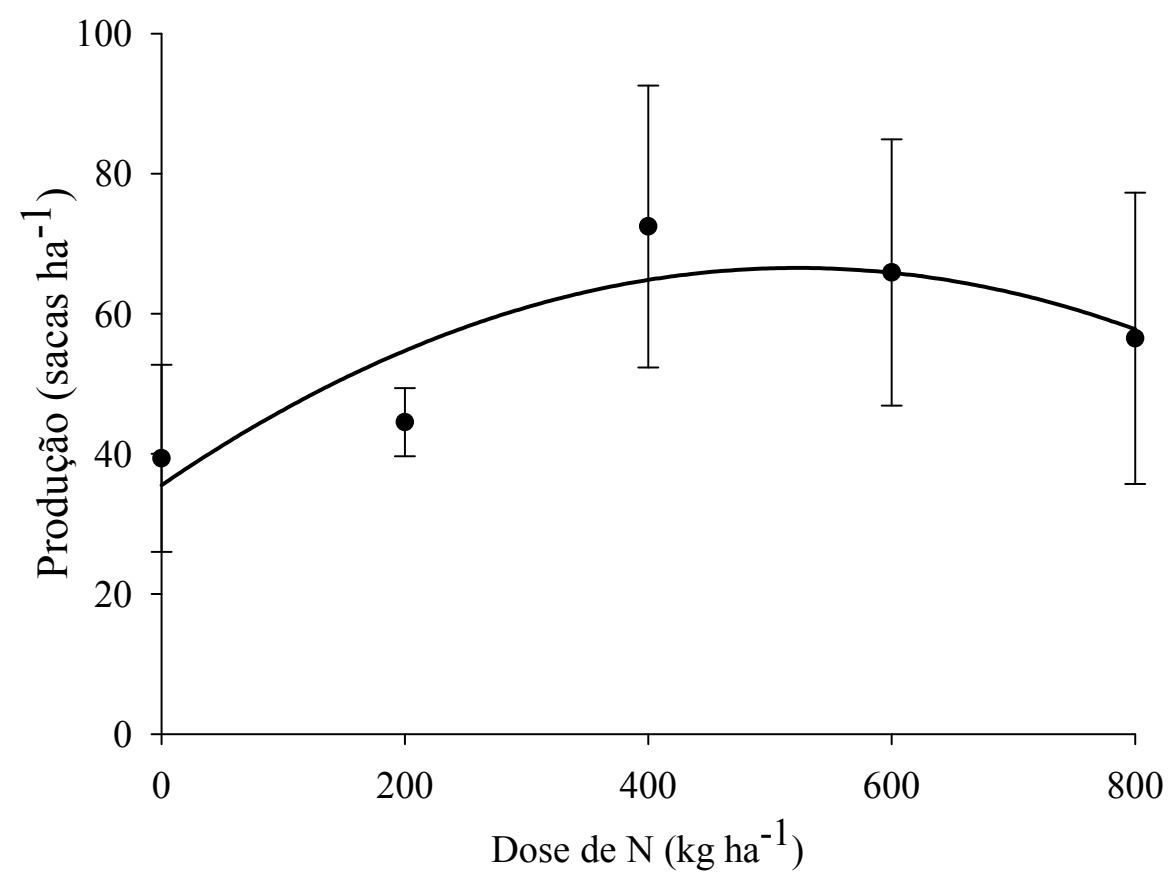

Figura 21 - Produtividade das plantas em função das doses de $\mathrm{N}$ aplicado. Equação de regressão: $\hat{y}=35,525+0,119 x-0,0001 x^{2}\left(R^{2}=0,77\right)$ 


\subsection{Concentrações foliares de macro e micronutrientes - Oeste baiano}

As concentrações de macronutrientes nas folhas variaram em função da fenologia da planta para todos os macronutrientes $(\mathrm{P}, \mathrm{K}, \mathrm{Ca}, \mathrm{Mg}$ e $\mathrm{S})$. Não foi verificada variação nas concentrações com a dose de N (Tabela 9).

Tabela 9 - Resumo do nível de significância para os fatores dose, fenologia e interação dose vs fenologia

\begin{tabular}{cccc}
\hline Variável & Dose & Fenologia & Interação Dose vs Fenologia \\
\hline $\mathrm{P}$ & 0,4365 & $<0,0001^{*}$ & 0,5703 \\
$\mathrm{~K}$ & 0,1807 & $<0,0001^{*}$ & 0,6388 \\
$\mathrm{Ca}$ & 0,1431 & $<0,0001^{*}$ & 0,8736 \\
$\mathrm{Mg}$ & 0,7259 & $<0,0001^{*}$ & 0,1669 \\
$\mathrm{~S}$ & 0,9608 & $<0,0001^{*}$ & 0,3502 \\
\hline
\end{tabular}

$*$ significativo ao nível de $5 \%$ de probabilidade $(\mathrm{p}<0,05)$

$\mathrm{O}$ fósforo $(\mathrm{P})$ desempenha importantes funções nas plantas, como a geração de energia, síntese de ácidos nucléicos, fotossíntese, glicólise, respiração, síntese e estabilidade de membranas, ativação e inativação de enzimas, reações redox, sinalização, metabolismo de carboidratos e nitrogênio (VANCE et al., 2003).

$\mathrm{Na}$ presente pesquisa, verificou-se variação nas concentrações de $\mathrm{P}$ nas diferentes fases fenológicas do cafeeiro. A maior concentração de $\mathrm{P}$ foi observada na granação e maturação (Figura 22; Tabela 10), o que indica que houve adequado suprimento de $\mathrm{P}$ pelo solo e a taxa de absorção do nutriente pelas raízes foi suficiente para atender a demanda dos frutos e folhas, uma vez que a partir da fase chumbinho as concentraçoes de P são consideradas adequadas $(1,6$ a 1,9 g $\mathrm{kg}^{-1}$ ) (MALAVOLTA; VITTI; OLIVEIRA, 1997).

Tabela 10 - Média da concentração de macronutrientes em razão da fase fenológica

\begin{tabular}{lcrrrrc}
\hline \multicolumn{1}{c}{ Nutrientes } & VG & Antese & \multicolumn{1}{c}{ CH } & GR1 & GR2 & MA \\
\hline $\mathrm{P}$ & $1,48 \mathrm{c}$ & $1,51 \mathrm{c}$ & $1,60 \mathrm{cb}$ & $1,72 \mathrm{ab}$ & $1,84 \mathrm{a}$ & $1,77 \mathrm{a}$ \\
$\mathrm{K}$ & $21,40 \mathrm{a}$ & $22,10 \mathrm{a}$ & $21,29 \mathrm{a}$ & $21,33 \mathrm{a}$ & $19,20 \mathrm{~b}$ & $19,05 \mathrm{~b}$ \\
$\mathrm{Ca}$ & $12,78 \mathrm{~b}$ & $10,62 \mathrm{c}$ & $7,47 \mathrm{~d}$ & $10,69 \mathrm{c}$ & $12,51 \mathrm{~b}$ & $14,45 \mathrm{a}$ \\
$\mathrm{Mg}$ & $3,06 \mathrm{bc}$ & $2,71 \mathrm{c}$ & $2,80 \mathrm{c}$ & $3,05 \mathrm{c}$ & $3,27 \mathrm{~b}$ & $3,80 \mathrm{a}$ \\
$\mathrm{S}$ & $1,80 \mathrm{~b}$ & $2,08 \mathrm{a}$ & $2,22 \mathrm{a}$ & $1,89 \mathrm{~b}$ & $2,11 \mathrm{a}$ & $2,13 \mathrm{a}$ \\
\hline
\end{tabular}

\footnotetext{
*médias seguidas pela mesma letra na horizontal não diferem entre si a $5 \%$ probabilidade.
} 
O Potássio $(\mathrm{K})$ é o elemento mineral mais abundante na planta, armazenado no vacúolo como íon livre, atua na regulação da pressão osmótica das células e é requerido na ativação de diversas enzimas essenciais à síntese de compostos orgânicos, incluindo açúcares solúveis e amido (MARSCHNER, 1995; MARENCO; LOPES, 2005) cuja síntese aumenta com a maturação dos frutos. Além disso, este nutriente participa do transporte pela membrana de outros íons e da abertura de estômatos, entre outras funções.

No período avaliado, foi observada maior concentração foliar do $\mathrm{K}$ nas fases de vegetação, antese, chumbinho e $\mathrm{GR}_{1}$. Posteriormente, há intensa redução na $\mathrm{GR}_{2}$ e maturação (Figura 22; Tabela 10). Esta constatação é explicada pela elevada demanda dos frutos e alta mobilidade do K, com remobilização do nutriente das folhas para os frutos nas fases finais de desenvolvimento dos mesmos, particularmente, a partir $\mathrm{GR}_{2}$, fase final de desenvolvimento dos frutos (MARSCHNER, 1995; EPSTEIN; BLOOM, 2006). Esta grande demanda na fase de granação sugere a necessidade de aplicação deste nutriente no período que antecede a fase de enchimento dos grãos, que pelo presente experimento pode ocorrer até o mês de janeiro. As concentrações de K não alcançaram níveis suficientes para a nutrição da planta, mesmo nas fases que apresentaram os maiores valores deste nutriente, uma vez que a classe adequada varia entre à 22 a $25 \mathrm{~g} \mathrm{~kg}^{-1}$ (MALAVOLTA; VITTI; OLIVEIRA, 1997).
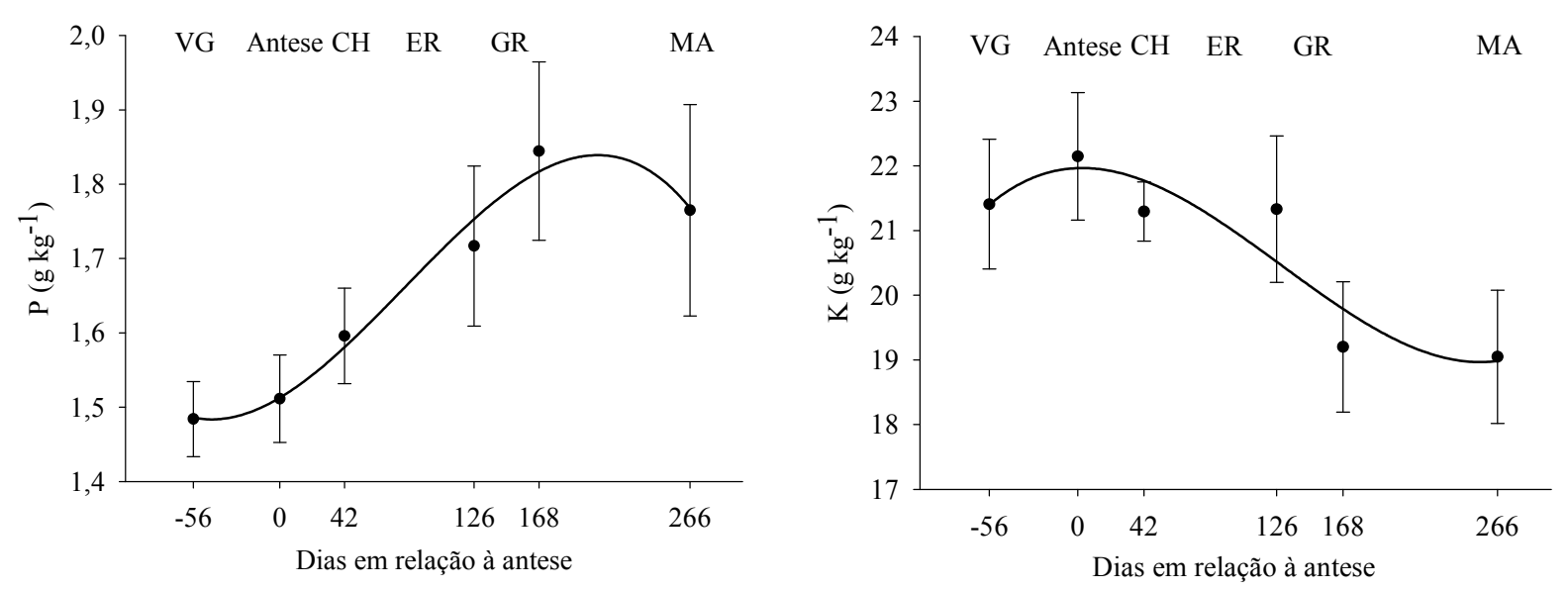

Figura 22 - Concentrações foliares de P e K em folhas de cafeeiro em função do tempo decorrido em relação à antese, nas fases fenológicas da planta (vegetação, antese, chumbinho, granação e maturação) 
O cálcio $(\mathrm{Ca})$ na planta tem função estrutural, é regulador enzimático e mensageiro secundário (MALAVOLTA, 2006). O Ca é essencial para a manutenção da integridade estrutural e funcional da membrana e da parede celular, com função na composição estrutural de macromoléculas. A maior parte deste nutriente está localizada nas paredes celulares (apoplasma). Seu papel na ativação enzimática se dá por meio do aumento na concentração desse cátion no citosol, que ativa as calmodulinas que, por sua vez, ativam numerosas enzimas. O Ca auxilia também na abertura do estômato e interage com o $\mathrm{K}$ nas relações osmóticas das células (EPSTEIN; BLOOM, 2006); atua na absorção iônica e tem papel na conversão de sinais vindos do ambiente. Estresses abióticos e bióticos causam aumento na concentração de cálcio no citoplasma.

No experimento, as maiores concentrações de Ca foram verificados na fase de vegetação, $\mathrm{GR}_{2}$ e maturação (Figura 24). Por sua vez, as menores concentrações foram observadas na fase de fruto chumbinho, o que corrobora os dados obtidos por Chaves (1982), o qual relatou que em folhas de ramos com frutos, os teores do nutriente foram mais baixos nas primeiras fases do desenvolvimento do fruto. Este nutriente apresenta baixa mobilidade no floema e seu suprimento aos frutos e folhas depende da absorção do solo. No solo, o Ca é transportado por fluxo de massa e é altamente dependente do teor de água. Na planta, o transporte desse íon é dependente da abertura estomática, que é reduzida sob altas temperaturas. Quando os estômatos estão abertos, a planta perde água pela transpiração, o que incrementa a absorção de $\mathrm{Ca}$ e de outros nutrientes pelas raízes. No município de Luiz Eduardo Magalhães, constatou-se que a transpiração é reduzida no período da tarde (Figura 23). Além disso, verificou-se maior temperatura em outubro (Figura 5), durante a antese, quando as concentrações foliares de Ca foram reduzidas. Laviola (2007a) observou intenso acúmulo nos frutos na fase de chumbinho, o que indica que o suprimento deste nutriente pode não ter sido suficiente para atender a demanda dos frutos e folhas que cresceram neste período. Outra explicação possível para a redução da concentração foliar nas fases de antese e chumbinho está relacionada com a força dreno dos órgãos em crescimento (folhas jovens, flores e principalmente os frutos). 


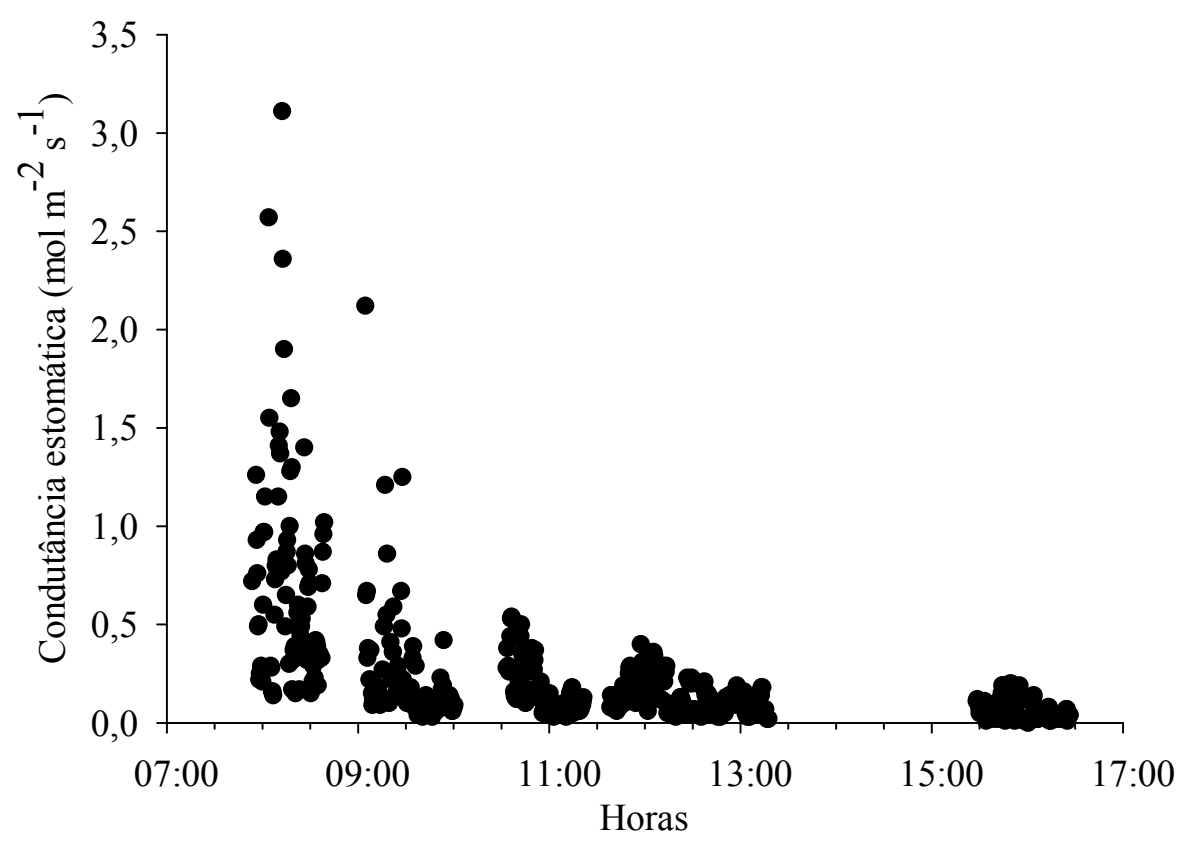

Figura 23 - Condutância estomática em folhas de cafeeiro em função da hora do dia, realizadas nas duas épocas de avaliação da granação $\left(\mathrm{GR}_{1}\right.$ e $\left.\mathrm{GR}_{2}\right)$

As principais funções do magnésio no metabolismo da planta estão relacionadas à clorofila, ativação de enzimas e "carregador" do P. Aproximadamente $10 \%$ da concentração de $\mathrm{Mg}$ foliar está presente na clorofila. O Mg é o elemento que mais atua na ativação de enzimas, é co-fator de todas as enzimas fosforilativas, as quais atuam nos processos de fotossíntese, respiração, síntese de compostos orgânicos e absorção iônica. Em deficiência extrema, o metabolismo do $\mathrm{N}$ também é afetado, como a síntese de proteínas e de aminoácidos. Outra função importante é de "carregador de P" por sua participação na ativação de ATPase da membrana implicada na absorção, inclusive na geração do ATP na fotossíntese e respiração (MALAVOLTA, 2006; VITTI; LIMA; CICARONE, 2006).

No período avaliado verificaram-se nas fases de antese e chumbinho as menores concentrações foliares de $\mathrm{Mg}$ (Figura 24). O fruto na fase chumbinho apresenta alta taxa respiratória (RENA; BARROS; MAESTRI, 2001) e, conseqüentemente, maior atividade de ATPase (MARSCHNER, 1995), o que demanda maior quantidade de Mg pela planta. Além disso, o Mg é abundante em tecidos novos, como órgãos em crescimento (flores, grãos, folhas, ramos e raízes), que são alimentados via floema. Estes dados corroboram àqueles obtidos por 
Silva e Souza et al. (1975) citados por Chaves (1982) que constataram que as concentrações de magnésio aumentaram constantemente nas folhas de ramos com frutos. Há relação direta entre as concentrações de Mg e P, uma vez que a concentração de P aumenta (Figura 22) com a maior concentração de $\mathrm{Mg}$ (Figura 24). Esta observação confirma a função do Mg como "carregador de P” (MALAVOLTA, 2006).

Em nenhuma das fases avaliadas, a concentração de $\mathrm{Mg}$ esteve na classe considerada adequada (4 a 4,5 $\mathrm{g} \mathrm{kg}^{-1}$ ) (MALAVOLTA; VITTI; OLIVEIRA, 1997). Esta constatação possivelmente se deve a redução na absorção do $\mathrm{Mg}$ do solo, que mesmo estando com teor igual a $9 \mathrm{mmol}_{\mathrm{c}} \mathrm{dm}^{-3}$, pode ter sido inibida por $\mathrm{K}$, como indica a Figura 22, em que as maiores concentrações de K coincidem com a menor concentração de Mg (Figura 24).
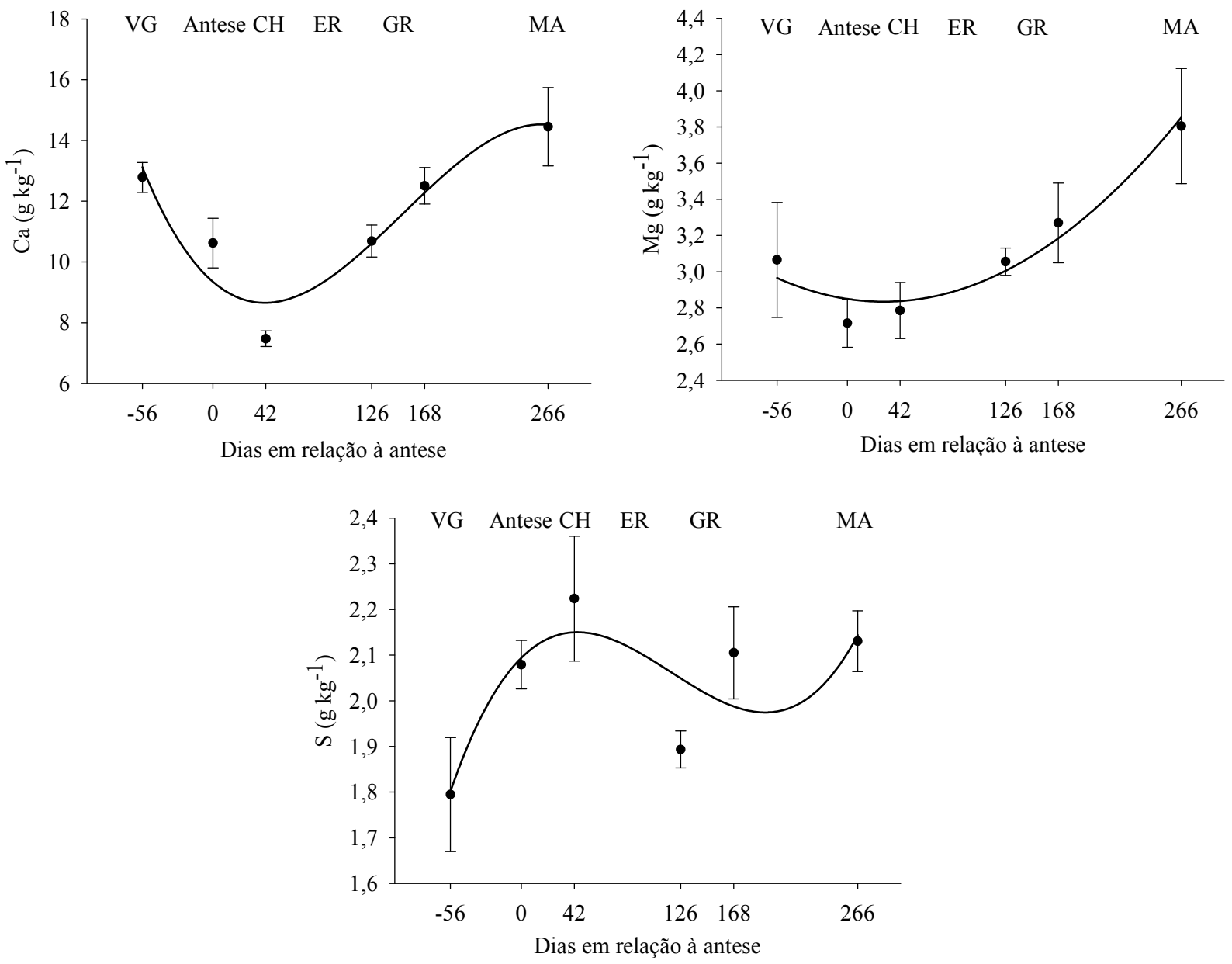

Figura 24 - Concentrações foliares de $\mathrm{Ca}, \mathrm{Mg}$ e $\mathrm{S}$ em folhas de cafeeiro em função do tempo decorrido em relação à antese, nas fases fenológicas da planta (vegetação, antese, chumbinho, granação e maturação) 
O enxofre participa da constituição, entre outros, dos aminoácidos tirosina, cisteína e metionina e das proteínas que os contém, além de desempenhar funções estruturais, como as ligações dissulfeto que conferem estrutura secundária às proteínas; e metabólicas, devido aos aminoácidos em proteínas, aminoácidos livres e outros compostos de $\mathrm{S}$ de baixo peso molecular (VITTI; LIMA; CICARONE, 2006).

Na presente pesquisa, verifica-se que o padrão de concentração de $\mathrm{S}$ foi semelhante ao de $\mathrm{N}$ foliar, o que pode ser explicado pela relação do enxofre com o metabolismo do N (VITTI et al., 1988). As maiores concentrações foram observadas nas fases de antese e chumbinho e as menores na fase vegetativa e na granação (Figura 24; Tabela 10). Esta diminuição da concentração foliar de S na fase inicial da granação pode ser explicada pela translocação de aminoácidos para a formação dos grãos. Grande parte do enxofre é assimilada e exportada pelo floema para os locais de síntese protéica (frutos e ápices caulinares e radiculares), principalmente na forma de glutationa (VITTI; LIMA; CICARONE, 2006). A concentração foliar de S, em todas as fases fenológicas, foi igual ou superior a classe adequada (1,5 a $2 \mathrm{~g} \mathrm{~kg}^{-1}$ ) (MALAVOLTA; VITTI; OLIVEIRA, 1997)

Na tabela 11 são apresentadas as equações de regressão ajustadas para as concentrações de macronutrientes nas diferentes fases fenológicas.

Tabela 11 - Equações de regressão da variação das concentrações de $\mathrm{P}, \mathrm{K}, \mathrm{Ca}, \mathrm{Mg}$ e $\mathrm{S}$ em folhas de cafeeiros em função do tempo decorrido em relação à antese (dias)

\begin{tabular}{lll}
\hline Variável & Modelo & $\mathrm{R}^{2}$ \\
\hline $\mathrm{P}$ & $\hat{\mathrm{y}}=1,513+0,0012 \mathrm{x}+0,000111 \mathrm{x}^{2}-0,0000000459 \mathrm{x}^{3}$ & 0,978 \\
$\mathrm{~K}$ & $\hat{\mathrm{y}}=21,965+0,0008 \mathrm{x}-0,0001 \mathrm{x}^{2}+0,000000375 \mathrm{x}^{3}$ & 0,847 \\
$\mathrm{Ca}$ & $\hat{\mathrm{y}}=9,347-0,0357 \mathrm{x}+0,0005 \mathrm{x}^{2}-0,00000111 \mathrm{x}^{3}$ & 0,890 \\
$\mathrm{Mg}$ & $\hat{y}=2,763-0,0022 \mathrm{x}+0,000047 \mathrm{x}^{2}-0,0000000899 \mathrm{x}^{3}$ & 0,994 \\
$\mathrm{~S}$ & $\hat{\mathrm{y}}=2,094+0,0028 \mathrm{x}-0,0000382 \mathrm{x}^{2}+0,000000722 \mathrm{x}^{3}$ & 0,660 \\
\hline
\end{tabular}

As concentrações de micronutrientes nas folhas, da mesma forma que as de macronutrientes, variaram em função da fenologia da planta para todos os elementos $(\mathrm{B}, \mathrm{Cu}, \mathrm{Fe}$, $\mathrm{Mn}$ e $\mathrm{Zn}$ ), no entanto, não observou variação nas concentrações com a dose de $\mathrm{N}$ aplicado (Tabela 12). 
Tabela 12 - Resumo do nível de significância para os fatores dose, fenologia e para a interação dose vs fenologia

\begin{tabular}{cccc}
\hline Variável & Dose & Fenologia & Interação Dose vs Fenologia \\
\hline $\mathrm{B}$ & 0,2309 & $<0,0001^{*}$ & 0,7866 \\
$\mathrm{Cu}$ & 0,5892 & $<0,0001^{*}$ & 0,4126 \\
$\mathrm{Fe}$ & 0,2211 & $<0,0001^{*}$ & 0,2320 \\
$\mathrm{Mn}$ & 0,5951 & $<0,0001^{*}$ & 0,3269 \\
$\mathrm{Zn}$ & 0,4517 & $<0,0001^{*}$ & 0,6343 \\
\hline
\end{tabular}

* significativo ao nível de $5 \%$ de prrobabilidade $(\mathrm{p}<0,05)$

Os micronutrientes, apesar de serem requeridos em baixas concentrações, da ordem de miligramas por quilograma de matéria seca, desempenham importante papel no metabolismo das plantas, sendo constituintes de enzimas, ou atuam como seus ativadores (DECHEN; NACHTIGALL, 2006).

O boro (B) é um micronutriente imóvel na planta, translocado no xilema e com pouca mobilidade no floema (RAVEN, 1980). Normalmente acumula nas folhas velhas (JONES JR., 1970) e sua deficiência ocorre nas zonas de crescimento da planta. O B tem importante função na translocação de açúcares e no metabolismo de carboidratos e atua nos processos de florescimento, crescimento do tubo polínico, frutificação, no metabolismo do N, na atividade de hormônios e no metabolismo de ácidos nucléicos (DECHEN; NACHTIGALL, 2006).

As concentrações foliares de B foram menores na fase de chumbinho (Figura 25; Tabela 13). O suprimento do nutriente às plantas se dá via fluxo de massa, enquanto a absorção pela planta depende do fluxo transpiratório. Nas fases da antese e chumbinho foram observadas as maiores temperaturas e, como conseqüência, a planta deve permanecer mais tempo com os estômatos fechados, em particular nas horas mais quentes do dia, reduzindo a transpiração foliar e, consequentemente, a absorção de nutrientes do solo. Laviola et al. (2007c) observou maior acúmulo de B e Zn nos frutos nas fases da antese e chumbinho. Na presente pesquisa constatou as menores concentrações de B nas folhas, o que indica que as aplicações de B devem ser iniciadas antes da fase chumbinho, para que não haja competição entre as folhas e os frutos durante as primeiras fases do período reprodutivo.

$\mathrm{O}$ cafeeiro esteve bem nutrido por $\mathrm{B}$ em todas as fases fenológicas, exceto na fase chumbinho, cuja concentração foliar foi inferior a classe adequada (50 a 60 mg $\mathrm{kg}^{-1}$ ) (MALAVOLTA; VITTI; OLIVEIRA, 1997). 
Tabela 13 - Média da concentração de micronutrientes em razão da fase fenológica

\begin{tabular}{lcccccc}
\hline Nutrientes & VG & Antese & CH & GR1 & GR2 & MA \\
\hline $\mathrm{B}$ & $63,50 \mathrm{ab}$ & $58,90 \mathrm{~b}$ & $42,06 \mathrm{c}$ & $61,44 \mathrm{~b}$ & $62,58 \mathrm{ab}$ & $70,69 \mathrm{a}$ \\
$\mathrm{Cu}$ & - & $35,60 \mathrm{~b}$ & $13,30 \mathrm{c}$ & $14,50 \mathrm{c}$ & $16,30 \mathrm{c}$ & $80,30 \mathrm{a}$ \\
$\mathrm{Mn}$ & $83,80 \mathrm{ab}$ & $74,00 \mathrm{bc}$ & $56,00 \mathrm{~d}$ & $67,50 \mathrm{~cd}$ & $67,20 \mathrm{~cd}$ & $94,60 \mathrm{a}$ \\
$\mathrm{Zn}$ & - & $14,50 \mathrm{a}$ & $10,30 \mathrm{~b}$ & $11,30 \mathrm{~b}$ & $10,30 \mathrm{~b}$ & $10,90 \mathrm{~b}$ \\
$\mathrm{Fe}$ & $171,10 \mathrm{a}$ & $113,00 \mathrm{~b}$ & $66,90 \mathrm{~d}$ & $61,90 \mathrm{~d}$ & $60,10 \mathrm{~d}$ & $88,90 \mathrm{c}$ \\
\hline
\end{tabular}

*médias seguidas pela mesma letra na horizontal não diferem entre si a 5\% probabilidade.
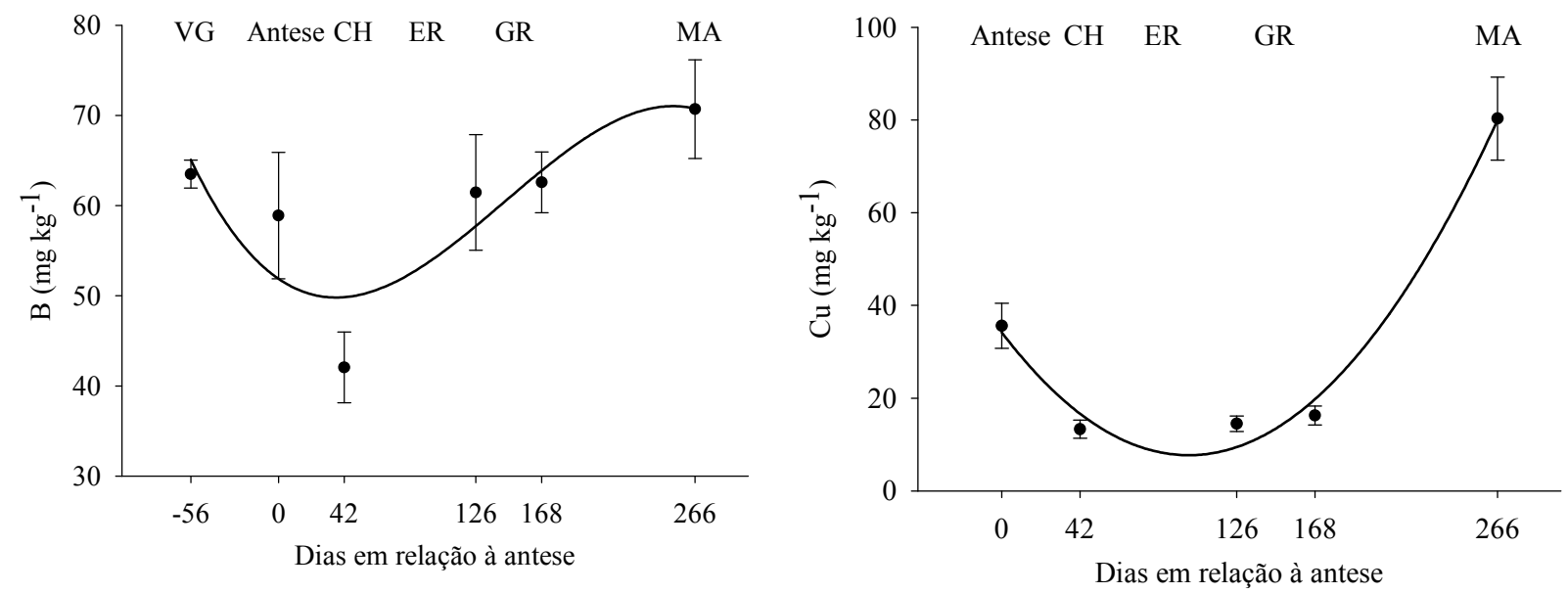

Figura 25 - Concentrações foliares de $\mathrm{B}$ e $\mathrm{Cu}$ em folhas de cafeeiro em função do tempo decorrido em relação à antese, nas fases fenológicas da planta (vegetação, antese, chumbinho, granação e maturação)

O cobre $(\mathrm{Cu})$ não é considerado móvel na planta, embora haja relatos de translocação de folhas velhas para folhas novas, em plantas bem nutridas. Segundo Loneragan (1981) esse nutriente pode ser transportado no xilema e floema junto com compostos nitrogenados solúveis, como os aminoácidos, já que o $\mathrm{Cu}$ apresenta alta afinidade com o grupo amino. $\mathrm{O} \mathrm{Cu}$ atua como transportador de elétrons e é constituinte de diversas proteínas e enzimas, como a oxidase do ácido ascórbico (vitamina C), a citocromo-oxidase, a superóxido dismutase e a plastocianina, doadora de elétrons para o fotossistema $\mathrm{I}$. $\mathrm{O} \mathrm{Cu}$ se acumula em órgãos reprodutivos das plantas (DECHEN; NACHTIGALL, 2006; EPSTEIN; BLOOM; 2006).

No período avaliado, foi observada variação de concentração de $\mathrm{Cu}$ nas folhas, em que as maiores concentrações foram observadas nas fases iniciais (antese) e finais do ciclo reprodutivo (MA). As menores concentrações foram observadas nas fases de chumbinho, $\mathrm{GR}_{1}$ e $\mathrm{GR}_{2}$ (Figura 
25; Tabela 13). Chaves (1982) também observou maior concentração nas fases iniciais do ciclo reprodutivo do cafeeiro, confirmado posteriormente por Gonçalves (2007). Para Laviola et al. (2007c) a concentração mínima de $\mathrm{Cu}$ ocorreu na fase de granação.

Apesar das menores concentrações de $\mathrm{Cu}$ nas fases reprodutivas, a concentração do nutriente se manteve adequada (11 a $14 \mathrm{mg} \mathrm{kg}^{-1}$ ) (MALAVOLTA; VITTI; OLIVEIRA, 1997). Ressalta-se que as altas concentrações na antese $\left(35,6 \mathrm{mg} \mathrm{kg}^{-1}\right)$ e na maturação $\left(80,3 \mathrm{mg} \mathrm{kg}{ }^{-1}\right)$ podem ser contaminações por fungicidas cúpricos, em que o nutriente permanece na superfície foliar.

O ferro $(\mathrm{Fe})$ atua na ativação de enzimas, participa de reações de oxido redução em citocromos, leghemoglobinas, catalase, peroxidase, superóxido dismutase, ferredoxina e enzimas redutase, nitrogenase e sulfato redutase. O Fe cataliza a biossíntese da clorofila, por fazer parte de enzimas responsáveis pela sua formação, sem o qual a planta apresentaria apenas pigmentos amarelos (xantofilas e caroteno) (DECHEN; NACHTIGALL, 2006).

No experimento, as maiores concentrações de Fe foram observadas na fase vegetativa (Figura 26; Tabela 13). Altas concentrações de P afetam a mobilidade de Fe nos tecidos, razão por que as curvas de concentração são inversas como observado na figura 22 (P) e figura 26 (S). Da mesma forma deficiência de K verificada na granação e maturação (Figura 22) também afeta sua mobilidade, o que contribui para a menor concentração de $\mathrm{Fe}$, conforme constatado anteriormente por Dechen e Nachtigall (2006).

O manganês (Mn) apresenta absorção controlada metabolicamente de forma semelhante ao Mg e Ca. O Mn é pouco móvel no floema, o que é responsável pela sua baixa concentração em frutos, sementes e órgãos de reserva nas raízes. Tem função na síntese de clorofila e na ativação de enzimas, principalmente àquelas envolvidas no metabolismo intermediário. Participa do fotossistema II e na fotólise da água.

As maiores concentrações de Mn foram observadas na fase de vegetação e na maturação dos frutos (Figura 26). Estes dados corroboram aqueles obtidos por Laviola et al (2007c), os quais observaram o mesmo padrão de variação da concentração de Mn nas plantas durante um ciclo de produção. Chaves (1982) também constatou aumento na concentração de Mn na fase final da frutificação. As concentrações foliares de Mn ocorreram na classe adequada na fase vegetativa e na maturação (80 a $100 \mathrm{mg} \mathrm{kg}^{-1}$ ) (MALAVOLTA; VITTI; OLIVEIRA, 1997). 
O zinco ( $\mathrm{Zn})$ é considerado um nutriente altamente móvel na planta, atua como cofator de mais de 80 enzimas e é essencial para a atividade, regulação e estabilização da estrutura protéica. Entre os principais processos que o $\mathrm{Zn}$ participa estão a fotossíntese, a respiração, a síntese de aminoácidos e proteínas e o controle hormonal, principalmente na produção de ácido indolacético (AIA).

No presente trabalho observou variação significativa na concentração foliar de $\mathrm{Zn}$, em que as maiores concentrações foram observadas na antese. A partir dessa fase, as concentrações do nutriente diminuíram (Figura 26). Esses dados corroboram os dados obtidos por Chaves (1982), que observou decréscimo na concentração de $\mathrm{Zn}$ até o aparecimento do chumbinho, após esta fase houve um aumento até os 172 dias do ciclo, diminuindo, posteriormente até a colheita dos frutos. As concentrações foliares de $\mathrm{Zn}$ estiveram abaixo da classe adequada (15 a $20 \mathrm{mg} \mathrm{\textrm {kg } ^ { - 1 }}$ ) (MALAVOLTA; VITTI; OLIVEIRA, 1997). 

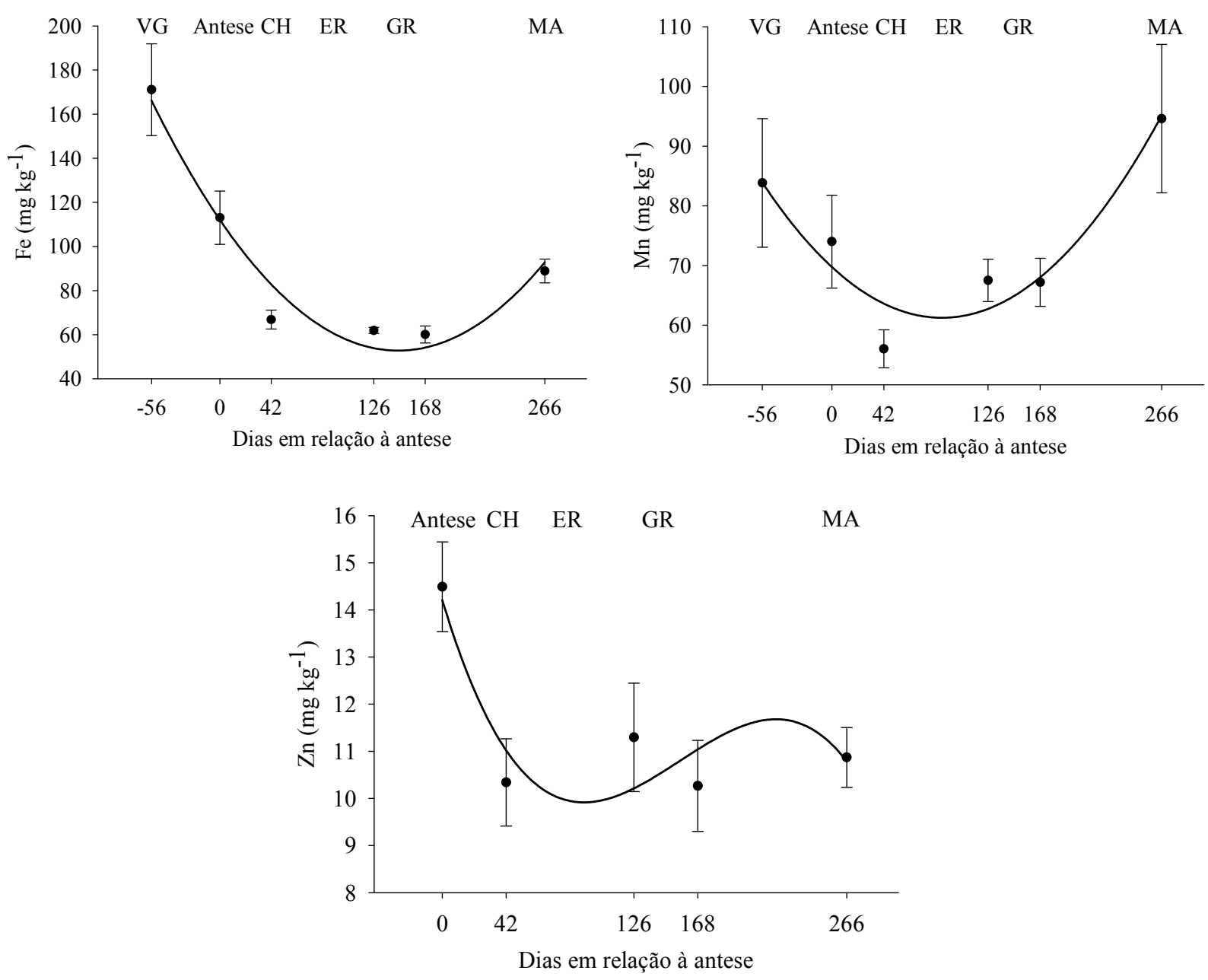

Figura 26 - Concentrações foliares de Fe, Mn e Zn em folhas de cafeeiro em função do tempo decorrido em relação à antese, nas fases fenológicas da planta (vegetação, antese, chumbinho, granação e maturação)

O fornecimento de micronutrientes ao cafeeiro, via solo ou via folha deve-se iniciar antes da fase de expansão rápida do fruto (GUIMARÃES et al., 1999; RENA; FAVARO, 2000). Nas condições do presente experimento, a concentração dos micronutrientes seguiu quase sempre o mesmo comportamento, com maiores concentrações nas fases de vegetação e antese, seguida de um declínio na fase de desenvolvimento do fruto e, finalmente, aumento das concentrações na fase de maturação.

Na tabela 14 são apresentadas as equações de regressão ajustadas para as concentrações de micronutrientes nas diferentes fases fenológicas. 
Tabela 14 - Equações de regressão da variação nas concentrações de $\mathrm{B}, \mathrm{Cu}, \mathrm{Fe}, \mathrm{Mn}, \mathrm{Zn}$ em folhas de cafeeiros em função do tempo decorrido após a antese (dias)

\begin{tabular}{llc}
\hline Variável & Modelo & $\mathrm{R}^{2}$ \\
\hline $\mathrm{B}$ & $\hat{\mathrm{y}}=51,889-0,119 \mathrm{x}+0,0018 \mathrm{x}^{2}-0,00000427 \mathrm{x}^{3}$ & 0,721 \\
$\mathrm{Cu}$ & $\hat{\mathrm{y}}=34,172-0,528 \mathrm{x}+0,0026 \mathrm{x}^{2}$ & 0,984 \\
$\mathrm{Fe}$ & $\hat{\mathrm{y}}=112,007-0,812 \mathrm{x}+0,0028 \mathrm{x}^{2}$ & 0,957 \\
$\mathrm{Mn}$ & $\hat{y}=69,761-0,192 \mathrm{x}+0,0011 \mathrm{x}^{2}$ & 0,894 \\
$\mathrm{Zn}$ & $\hat{\mathrm{y}}=14,205-0,107 \mathrm{x}+0,0008 \mathrm{x}^{2}-0,00000175 \mathrm{x}^{3}$ & 0,810 \\
\hline
\end{tabular}

\subsection{Características do solo e clima de Piracicaba}

A calagem e a gessagem da área experimental foram realizadas em setembro. $\mathrm{Na}$ implantação do experimento, em fevereiro, o solo apresentava $\mathrm{pH} 5,1$ nos primeiros $5 \mathrm{~cm}$ e pH 4,9 na camada de 5 a $15 \mathrm{~cm}$, valores considerados ácidos (Tabela 2). Os teores de Ca no solo eram elevados $\left(72 \mathrm{mmol}_{\mathrm{c}} \mathrm{dm}^{-3}\right.$ nos primeiros $5 \mathrm{~cm}$ e $39 \mathrm{mmol}_{\mathrm{c}} \mathrm{dm}^{-3}$ de 5 a $\left.15 \mathrm{~cm}\right)$ e $\mathrm{Mg}(25$

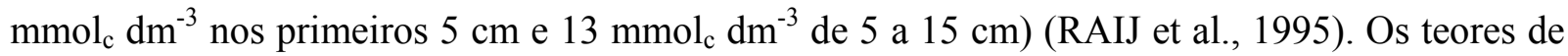
matéria orgânica do solo foram de $38 \mathrm{~g} \mathrm{dm}^{-3}$ nos primeiros $5 \mathrm{~cm}$ e $23 \mathrm{~g} \mathrm{dm}^{-3} 3 \mathrm{de} 5 \mathrm{a} 15 \mathrm{~cm}$. O teor de $\mathrm{P}$ é muito alto nos primeiros $5 \mathrm{~cm}\left(74 \mathrm{mg} \mathrm{dm}^{-3}\right)$ e de 5 a $15 \mathrm{~cm}\left(66 \mathrm{mg} \mathrm{dm}^{-3}\right)$.

O solo apresenta teor alto de $\mathrm{K}$ (aproximadamente $5,5 \mathrm{mmol}_{\mathrm{c}} \mathrm{dm}^{-3}$ nas camadas de 0 a 25 $\mathrm{cm})$. No início do experimento foi realizada uma adubação com potássio, em fevereiro.

Quanto aos micronutrientes, o solo apresentava, aproximadamente, os seguintes teores: B $\left(0,5 \mathrm{mg} \mathrm{dm}^{-3}\right), \mathrm{Cu}\left(6,5 \mathrm{mg} \mathrm{dm}^{-3}\right), \mathrm{Zn}\left(12 \mathrm{mg} \mathrm{dm}^{-3}\right)$ e $\mathrm{Mn}\left(63 \mathrm{mg} \mathrm{dm}^{-3}\right)$ na camada de 0 a $25 \mathrm{~cm}$.

Pelos dados climáticos, pode-se observar que as chuvas foram bem distribuídas ao longo do ano (Figura 7). No período do experimento, verificou-se déficit hídrico nos meses de abril e maio. Neste período, foram realizadas três irrigações localizadas nas parcelas experimentais para amenizar a deficiência hídrica das plantas e para que esta não prejudicasse a absorção e translocação dos nutrientes e fotoassimilados. Durante o experimento houve grande variação térmica, com temperatura mínima de $2,7{ }^{\circ} \mathrm{C}$ no mês de junho e máxima de $35^{\circ} \mathrm{C}$ no mês de março.

\subsection{Metabolismo do N - Piracicaba}

Este experimento foi realizado com a finalidade de verificar o pico máximo da enzima RN após a aplicação do fertilizante. A aplicação de $\mathrm{N}$ foi realizada em uma única vez, no dia 26 de fevereiro de 2009. Na referida pesquisa verificou interação significativa entre dose de $\mathrm{N}$ e o 
tempo após a adubação nitrogenada para as variáveis: concentração foliar de $\mathrm{N}$, aminoácidos totais solúveis, concentração de nitrato e amônio, enquanto para a atividade da redutase do nitrato não constatou significância para a interação (Tabela 12).

Tabela 15 - Resumo do nível de significância para os fatores dose, dias após a adubação nitrogenada e para a interação dose vs dias

\begin{tabular}{llcc}
\hline \multicolumn{1}{c}{ Variável } & Dose & Dias após adubação & Interação Dose $v s$ Dias \\
\hline $\mathrm{N}$ & $0,0048^{*}$ & $<0,0001^{*}$ & $0,0002^{*}$ \\
$\mathrm{ATS}$ & $0,0033^{*}$ & $<0,0001^{*}$ & $<0,0001^{*}$ \\
$\mathrm{NO}_{3}{ }^{-}$ & $0,0007^{*}$ & $<0,0001^{*}$ & $<0,0001^{*}$ \\
$\mathrm{NH}_{4}{ }^{+}$ & 0,0501 & $<0,0001^{*}$ & $0,0003^{*}$ \\
$\mathrm{RN}$ & $0,0416^{*}$ & $<0,0001^{*}$ & 0,2120 \\
\hline
\end{tabular}

* significativo ao nível de $5 \%(\mathrm{p}<0,05)$

Na primeira avaliação, aos 4 dias após a adubação, o cafeeiro apresentava concentração média de 24,2 $\mathrm{g} \mathrm{kg}^{-1}$ de $\mathrm{N}$ (Figura $27 \mathrm{~A}$ ), inferior à classe adequada (29 a $32 \mathrm{~g} \mathrm{~kg}^{-1}$ ) (MALAVOLTA, 2006). Com a aplicação de $200 \mathrm{~kg} \mathrm{ha}^{-1}$ de $\mathrm{N}$ observou aumento na concentração foliar de $\mathrm{N}$ até os 49 dias após a adubação, mesmo na fase de granação, época de intensa remobilização de $\mathrm{N}$ em que a concentração de $\mathrm{N}$ total variou de $23,6 \mathrm{~g} \mathrm{~kg}^{-1}$ aos 4 dias para $25,5 \mathrm{~g}$ $\mathrm{kg}^{-1}$ aos 49 dias após a adubação. $\mathrm{O}$ aumento de $\mathrm{N}$ total foi atribuído ao acúmulo de nitrato, cuja concentração foliar variou de 63,8 a $145 \mathrm{mg} \mathrm{kg}^{-1}$, enquanto o amônio passou de $72,4 \mathrm{mg} \mathrm{kg}^{-1}$ para $74,4 \mathrm{mg} \mathrm{kg}^{-1}$ aos 49 da adubação (Figura $28 \mathrm{~A}$; Tabela 16). Logo, a aplicação de $200 \mathrm{~kg} \mathrm{ha}^{-1}$ de N foi suficiente para atender a demanda dos frutos, como indica o acúmulo de $\mathrm{N}$ foliar (Figura 28 A).

A aplicação de $800 \mathrm{~kg} \mathrm{ha}^{-1}$ de $\mathrm{N}$ resultou numa redução da concentração do $\mathrm{N}$ total de 23,6 $\mathrm{g} \mathrm{kg}^{-1}$ aos 4 dias da adubação, para 21,8 $\mathrm{g} \mathrm{kg}^{-1}$ aos 49 dias, embora tenha havido acúmulo de nitrato nas folhas, o que ocorreu em menor proporção quando comparado a aplicação de $200 \mathrm{~kg}$ $\mathrm{ha}^{-1}$. Nesta dose, possivelmente não houve absorção do $\mathrm{N}$ aplicado, já que o aumento da concentração de nitrato foi semelhante ao aumento que ocorreu sem aplicação de N (Figura 28 A).

No experimento observa-se decréscimo na concentração foliar de $\mathrm{N}$ em todas as doses, embora com a aplicação de $200 \mathrm{~kg} \mathrm{ha}^{-1}$ esse redução tenha sido retardada. Este decréscimo se deve a intensa demanda dos frutos para o enchimento dos grãos para atender a produtividades da ordem de 60 sacas ha ${ }^{-1}$. 
Após a maturação dos frutos, nos tratamentos com fornecimento de 200 e $800 \mathrm{~kg} \mathrm{ha}^{-1}$ de $\mathrm{N}$ há novamente aumento da concentração foliar de $\mathrm{N}$ (138 dias após a adubação - DAAd) (Figura 27 A - MA), em que as concentrações foliares atingiram 27,1 $\mathrm{g} \mathrm{kg}^{-1}$ de N (200 kg ha ${ }^{-1}$ de $\mathrm{N})$ e $25,1 \mathrm{~g} \mathrm{~kg}^{-1}$ de $\mathrm{N}\left(800 \mathrm{~kg} \mathrm{ha}^{-1}\right.$ de $\left.\mathrm{N}\right)$. Comportamento semelhante ocorreu para a concentração de aminoácidos com recuperação inferior pelo fornecimento de $200 \mathrm{~kg} \mathrm{ha}^{-1}$ de $\mathrm{N}$, cuja concentração na fase de maturação foi $1,08 \mathrm{mg} \mathrm{g}^{-1}$ de MS; enquanto na a dose de $800 \mathrm{~kg} \mathrm{ha}^{-1}$ de $\mathrm{N}$ chegou a $1,39 \mathrm{mg} \mathrm{g}^{-1}$ de MS. A elevação nas concentrações de aminoácidos se deve a ausência de demanda pelos frutos, já que estes estavam na maturação.
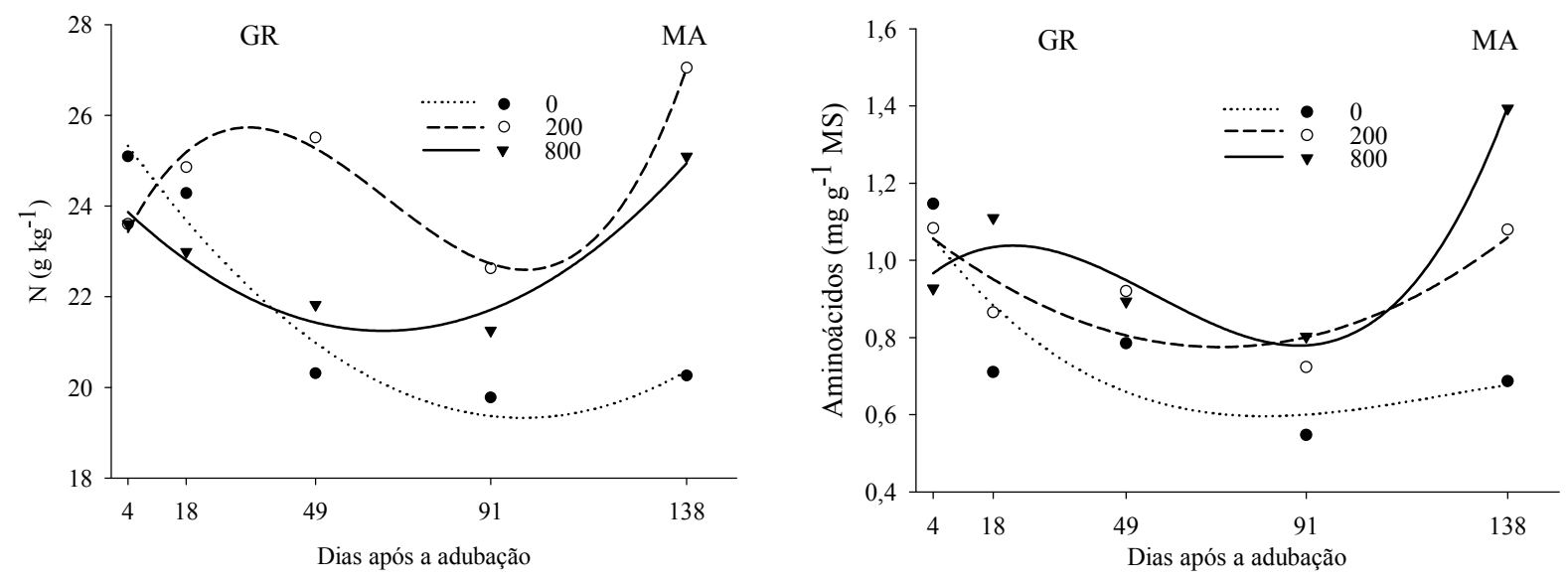

Figura 27 - Concentração de $\mathrm{N}$ e aminoácidos em folhas de cafeeiro em função do tempo decorrido após a adubação nitrogenada em cada dose de $\mathrm{N}$

Tabela 16 - Concentração de $\mathrm{NO}_{3}{ }^{-}$e $\mathrm{NH}_{4}{ }^{+}$em folhas $\left(\mathrm{mg} \mathrm{kg}^{-1}\right)$ aos 4, 18, 49, 91 e 138 dias após a adubação (DAAd) com 200 e $800 \mathrm{~kg} \mathrm{ha}^{-1}$ de N

\begin{tabular}{ccccccccccc}
\hline & 4 DAAd & \multicolumn{2}{c}{$18 \mathrm{DAAd}$} & 49 DAAd & \multicolumn{3}{c}{91 DAAd } & \multicolumn{3}{c}{$138 \mathrm{DAAd}$} \\
\hline & 200 & 800 & 200 & 800 & 200 & 800 & 200 & 800 & 200 & 800 \\
$\mathrm{NO}_{3}{ }^{-}$ & $63,8 \mathrm{c}$ & $63,8 \mathrm{~B}$ & $59,9 \mathrm{c}$ & $53,9 \mathrm{~B}$ & $145,3 \mathrm{ab}$ & $117,6 \mathrm{~A}$ & $184,0 \mathrm{a}$ & $63,0 \mathrm{~B}$ & $108,0 \mathrm{bc}$ & $145,2 \mathrm{~A}$ \\
$\mathrm{NH}_{4}{ }^{+}$ & $72,4 \mathrm{a}$ & $72,4 \mathrm{AB}$ & $45,5 \mathrm{a}$ & $44,1 \mathrm{~B}$ & $74,4 \mathrm{a}$ & $58,6 \mathrm{~B}$ & $57,8 \mathrm{a}$ & 69,1 & $178,9 \mathrm{~b}$ & $89,2 \mathrm{~A}$ \\
\hline
\end{tabular}

*médias seguidas pela mesma letra na horizontal não diferem entre si a $5 \%$ probabilidade: minúsculas $-200 \mathrm{~kg}$ $\mathrm{ha}^{-1}$ e maiúsculas $-800 \mathrm{~kg} \mathrm{ha}^{-1}$

A concentração de $\mathrm{NO}_{3}{ }^{-}$foliar variou no período em que as coletas foram realizadas (Tabela 12). Observa-se que na dose de $200 \mathrm{~kg} \mathrm{ha}^{-1}$, quando o $\mathrm{N}$ foliar aumentou logo após a adubação (18 e 49 DAAd) (Figura 27 A) houve também incremento na concentração de $\mathrm{NO}_{3}{ }^{-}$ foliar, cujo maior valor aconteceu aos 91 dias após a adubação (Figura 28 A). Na fase de 
maturação (138 DAAd) há redução no teor de $\mathrm{NO}_{3}{ }^{-}$reduziu enquanto a concentração de $\mathrm{NH}_{4}{ }^{+}$ aumentou (Figura $28 \mathrm{~B}$ ), o que indica que $\mathrm{o} \mathrm{NO}_{3}{ }^{-}$foi metabolizado pelas folhas. A atividade da RN também aumentou na fase de maturação, com fornecimento de $200 \mathrm{~kg} \mathrm{ha}^{-1}$ de N (Figura 29), explicada pela maior concentração de amônio proporcionada pela assimilação do nitrato. Nas plantas que não receberam $\mathrm{N}$ ou com a aplicação de $800 \mathrm{~kg}^{-1}$ houve menor acúmulo de $\mathrm{NO}_{3}{ }^{-} \mathrm{e}$ $\mathrm{NH}_{4}^{+}$nas plantas (Figura $28 \mathrm{~A}$; B). Nas plantas que receberam $800 \mathrm{~kg} \mathrm{ha}^{-1}$ de N, a quantidade inferior de $\mathrm{NO}_{3}{ }^{-}$e $\mathrm{NH}_{4}{ }^{+}$pode ser conseqüência da deficiência no metabolismo do $\mathrm{C}$ (fotossíntese) em fornecer cadeias carbônicas em níveis suficientes para atender a demanda da planta e, sem prejuízo para a assimilação do $\mathrm{N}$.

Apesar da semelhança de valores foliares de nitrato e amônio logo após a aplicação da uréia, independentemente das doses (200 e $800 \mathrm{~kg} \mathrm{ha}^{-1}$ de N; Figura 28) há predominância de nitrato a partir de 18 dias do fornecimento do nutriente. Aos 49 dias as concentrações de nitrato foram superiores para ambas as doses, enquanto o nível de amônio permanecia inferior (Figura 28 A). Esta observação indica que entre 18 e 49 dias após a adubação, com a granação em andamento, o cafeeiro foi submetido a uma elevada demanda energética para a assimilação do nitrato (13 ATPs) enquanto para a assimilação do amônio consume 2 ATPs, semelhante ao custo energético da maioria das reações biológicas, que varia entre 1 a 2 ATPs (TAIZ; ZEIGER, 2004).
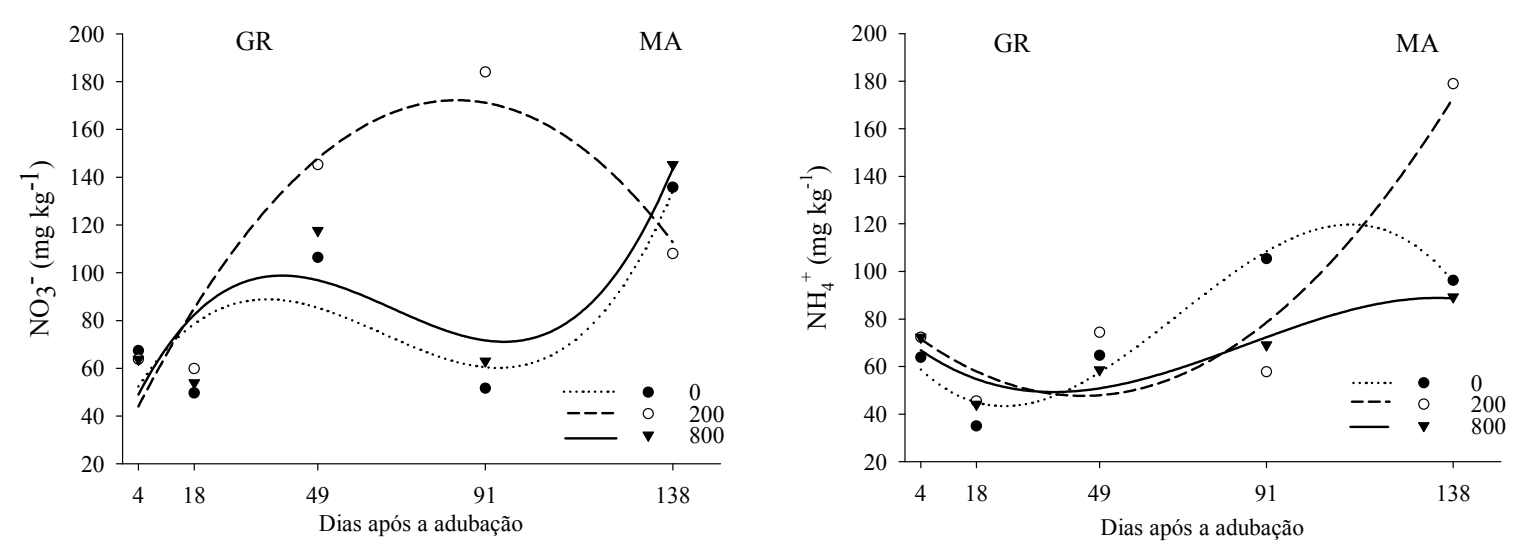

Figura 28 - Concentração de $\mathrm{NO}_{3}{ }^{-}$e $\mathrm{NH}_{4}{ }^{+}$em folhas de cafeeiro em função do tempo decorrido após a adubação nitrogenada em cada dose de $\mathrm{N}$

A redutase do nitrato apresentou aumento a partir do quarto dia da aplicação da uréia (Figura 29), com picos de atividade em diferentes épocas em razão da dose de N. O primeiro pico 
ocorreu aos 18 dias após a adubação com $800 \mathrm{~kg} \mathrm{ha}^{-1}$ de $\mathrm{N}$. Na ausência de $\mathrm{N}$ foi observado o menor pico aos 25 dias, que pode ter acontecido pelo uso do nitrato armazenados nas folhas, devido à elevada demanda para granação, uma vez que a produtividade foi elevada $(70,6$ sacas $\mathrm{ha}^{-1}$ ) (Figura 30). O fornecimento de $200 \mathrm{~kg} \mathrm{ha}^{-1}$ de $\mathrm{N}$ resultou em pico de atividade aos 32 dias após a aplicação. Esta observação pode ser explicada pelo aumento na concentração de nitrato foliar, que elevou a partir do $18^{\circ}$ dia após a adubação nitrogenada (Figura $28 \mathrm{~A}$; Tabela 16).

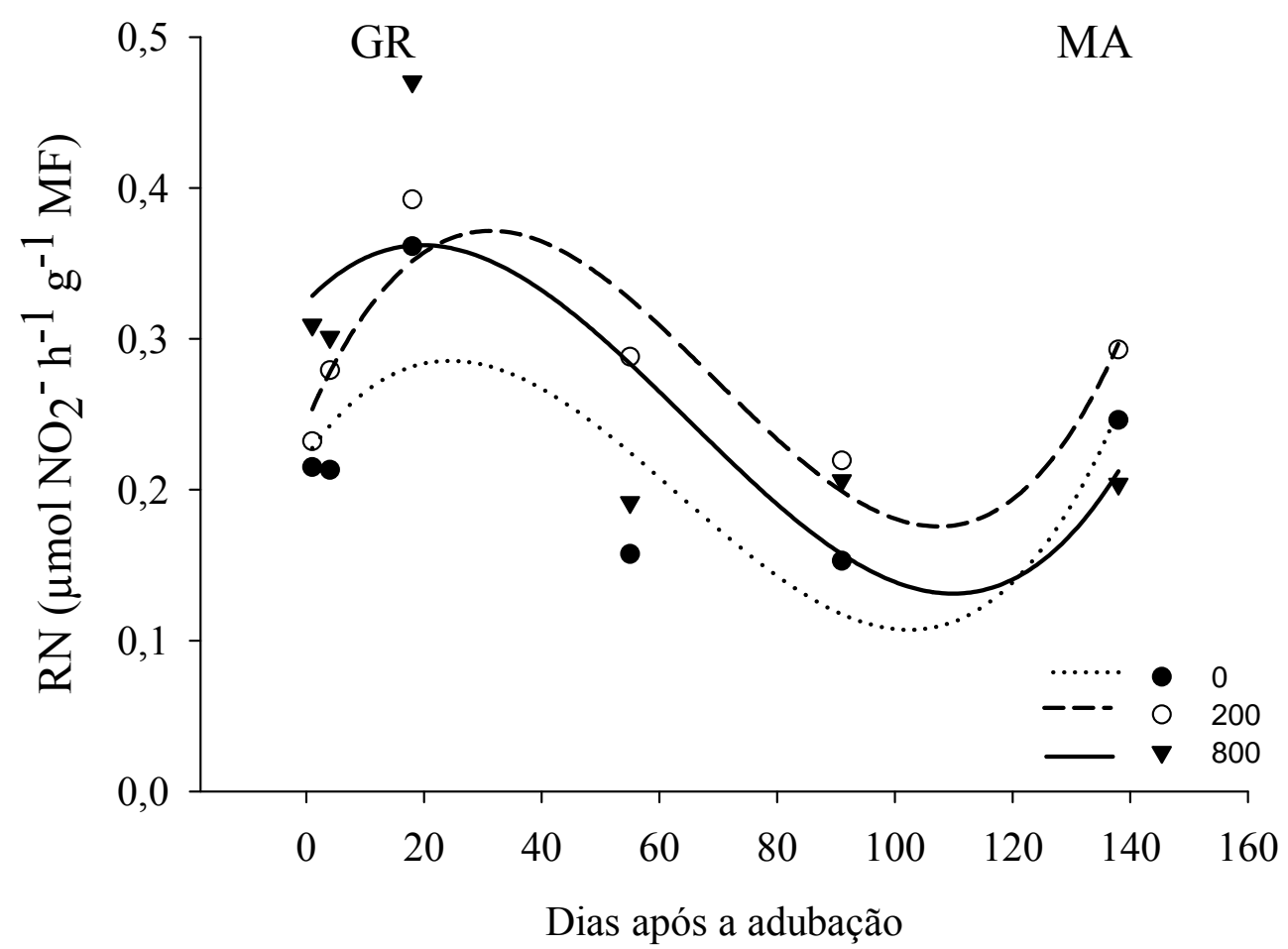

Figura 29 - Atividade da enzima redutase do nitrato em folhas de cafeeiro em função do tempo decorrido após a adubação nitrogenada em cada dose de $\mathrm{N}$

Na média das três doses de N (sem N, 200 e $800 \mathrm{~kg} \mathrm{ha}^{-1}$ de N) o pico da atividade da enzima ocorreu em época com elevada preciptação $(116,8 \mathrm{~mm})$ e maior temperatura média mínima $\left(16,2^{\circ} \mathrm{C}\right)$, em março de 2009 (Figura 7). Na avaliação feita em abril a atividade da RN estava em queda, fato que pode ser explicado pela baixa precipitação $(20 \mathrm{~mm})$ e temperatura mínima $\left(12,6{ }^{\circ} \mathrm{C}\right)$. Finalmente, a mínima atividade da $\mathrm{RN}$ ocorreu em junho com precipitação igual a $55,8 \mathrm{~mm}$ e temperatura mínima de $2,7^{\circ} \mathrm{C}$, provavelmente o principal fator limitante da atividade da enzima nesta época. A justificativa para tal afirmação fundamentou na elevação da atividade em julho, quando choveu $61,9 \mathrm{~mm}$ e a temperatura mínima elevou e atingiu $5,1{ }^{\circ} \mathrm{C}$ 
(Figura 29; Tabela 7). Nesta época, verificou-se a tendência de um segundo pico de atividade da enzima independentemente da dose de $\mathrm{N}$ aplicada. A sugestão a tendência se deve a falta de avaliação depois desta época.

Do exposto, pode-se afirmar que tanto a precipitação, quanto a temperatura mínima são fatores ambientais que atuam na regulação da atividade da enzima, corroborando as observações de Taleisnik et al. (1980).

$\mathrm{Na}$ tabela 17 são apresentadas as equações de regressão ajustadas para as concentrações de N, aminoácidos totais solúveis, nitrato, amônio, e atividade de RN nas folhas de cafeeiro após a adubação nitrogenada, ao londo do tempo.

Tabela 17 - Equações de regressão da variação das concentrações de $\mathrm{N}, \mathrm{ATS}, \mathrm{NO}_{3}{ }^{-}, \mathrm{NH}_{4}{ }^{+}$, RN em folhas de cafeeiros em função do tempo decorrido após a adubação nitrogenada (dias) em três doses de $\mathrm{N}$

\begin{tabular}{lclc}
\hline Variável & $\begin{array}{c}\text { Dose de N } \\
\left(\mathrm{kg} \mathrm{ha}^{-1}\right)\end{array}$ & Modelo & $\mathrm{R}^{2}$ \\
\hline \multirow{3}{*}{$\mathrm{N}$} & 0 & $\hat{\mathrm{y}}=25,849-0,132 \mathrm{x}+0,0006697 \mathrm{x}^{2}$ & 0,959 \\
& 200 & $\hat{\mathrm{y}}=22,656+0,21005 \mathrm{x}-0,00425 \mathrm{x}^{2}+0,00002144 \mathrm{x}^{3}$ & 0,982 \\
& 800 & $\hat{\mathrm{y}}=24,2197-0,0911 \mathrm{x}+0,000698 \mathrm{x}^{2}$ & 0,947 \\
\hline \multirow{3}{*}{$\mathrm{ATS}$} & 0 & $\hat{\mathrm{y}}=1,0790-0,01096 \mathrm{x}+0,0000588 \mathrm{x}^{2}$ & 0,707 \\
& 200 & $\hat{\mathrm{y}}=1,0908-0,00892 \mathrm{x}+0,0000629 \mathrm{x}^{2}$ & 0,702 \\
& 800 & $\hat{\mathrm{y}}=0,928+0,0106 \mathrm{x}-0,000294 \mathrm{x}^{2}+0,00000175 \mathrm{x}^{3}$ & 0,950 \\
\hline \multirow{3}{*}{$\mathrm{NO}_{3}{ }^{-}$} & 0 & $\hat{\mathrm{y}}=41,237+3,0156 \mathrm{x}-0,0576 \mathrm{x}^{2}+0,000295 \mathrm{x}^{3}$ & 0,720 \\
& 200 & $\hat{\mathrm{y}}=30,8198+3,376 \mathrm{x}-0,02015 \mathrm{x}^{2}$ & 0,892 \\
& 800 & $\hat{\mathrm{y}}=35,265+3,690 \mathrm{x}-0,0654 \mathrm{x}^{2}+0,000321 \mathrm{x}^{3}$ & 0,764 \\
\hline \multirow{3}{*}{$\mathrm{NH}_{4}{ }^{+}$} & 0 & $\hat{\mathrm{y}}=65,755-1,937 \mathrm{x}+0,0474 \mathrm{x}^{2}-0,000230 \mathrm{x}^{3}$ & 0,942 \\
& 200 & $\hat{\mathrm{y}}=76,424-1,286 \mathrm{x}+0,0144 \mathrm{x}^{2}$ & 0,884 \\
& 800 & $\hat{\mathrm{y}}=71,815-1,326 \mathrm{x}+0,02267 \mathrm{x}^{2}-0,0000882 \mathrm{x}^{3}$ & 0,809 \\
\hline \multirow{3}{*}{$\mathrm{RN}$} & 0 & $\hat{\mathrm{y}}=0,222+0,0056 \mathrm{x}-0,0001 \mathrm{x}^{2}+0,000000751 \mathrm{x}^{3}$ & 0,546 \\
& 200 & $\hat{\mathrm{y}}=0,245+0,009 \mathrm{x}-0,0002 \mathrm{x}^{2}+0,000000891 \mathrm{x}^{3}$ & 0,785 \\
& 800 & $\hat{\mathrm{y}}=0,324+0,0041 \mathrm{x}-0,0001 \mathrm{x}^{2}+0,000000628 \mathrm{x}^{3}$ & 0,568 \\
\hline
\end{tabular}

A doses de $\mathrm{N}$ não influenciaram a produtividade, uma vez que a aplicação se deu em fevereiro, quando a granação dos frutos já estava em andamento. As produtividades foram de 70,6 sacas ha $^{-1}(\mathrm{sem} \mathrm{N}) ; 58,2$ sacas ha $^{-1}\left(200 \mathrm{~kg} \mathrm{ha}^{-1}\right.$ de N) e 52,4 sacas ha ${ }^{-1}\left(800 \mathrm{~kg} \mathrm{ha}^{-1}\right.$ de N) (Figura 30). 


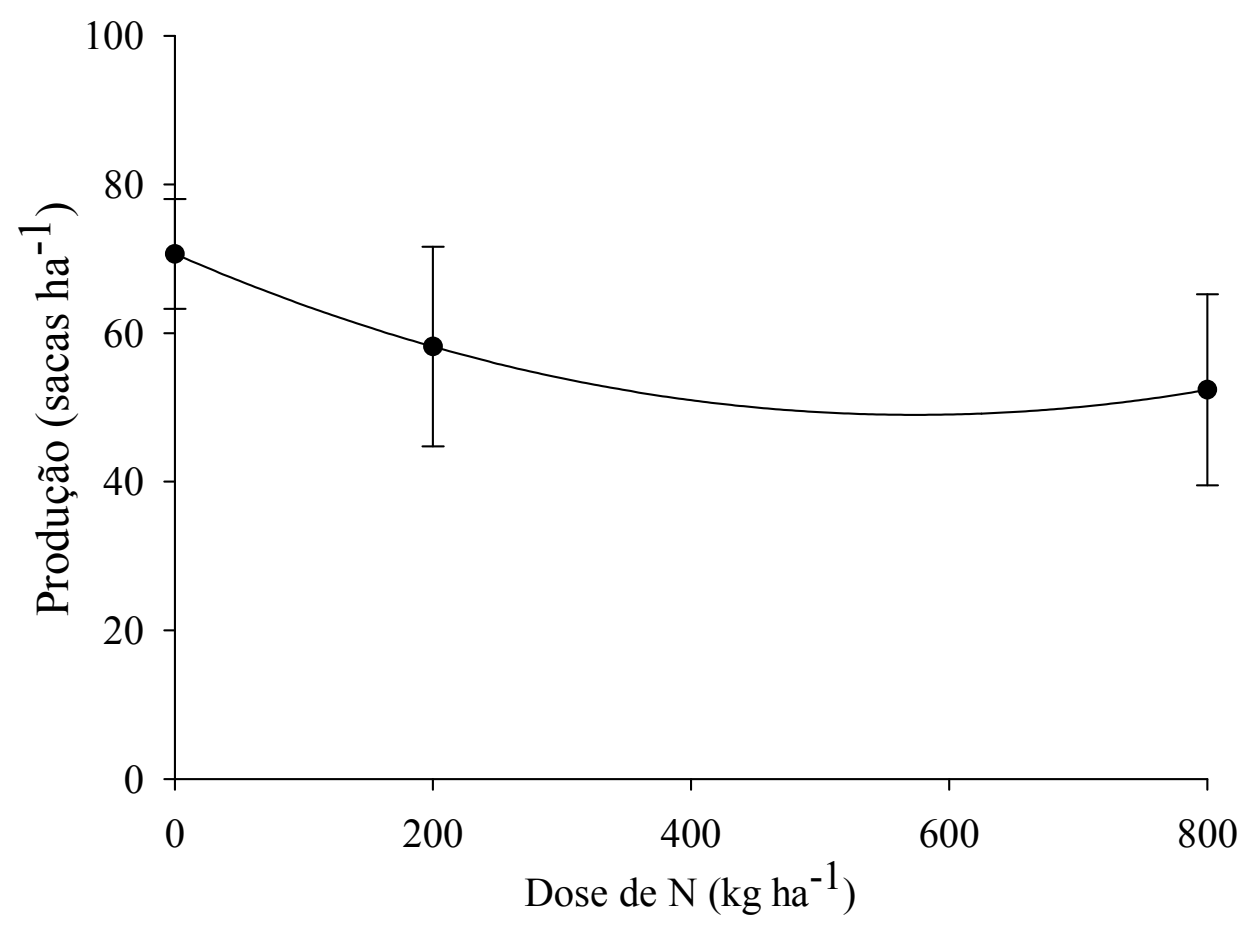

Figura 30 - Produtividade das plantas em função das doses de $\mathrm{N}$ aplicado 


\section{CONCLUSÕES}

1. A maior atividade da redutase do nitrato ocorre pelo fornecimento de $800 \mathrm{~kg} \mathrm{ha}^{-1}$ de $\mathrm{N}$, sem variação nas demais doses. A adubação nitrogenada, independentemente da dose, não afeta a atividade das enzimas glutamina sintetase e urease.

2. As concentrações de nitrato e amônio não aumentam com as doses de nitrogênio, no entanto a concentração de aminoácido é crescente com o aumento da dose do nutriente.

3. A maior atividade da redutase do nitrato verifica-se na fase de vegetação e granação dos frutos, a qual é superior às 12:00 h, enquanto das enzimas glutamina sintetase e urease acontecem nas fase de granação dos frutos.

4. A maior concentração de nitrato ocorre entre a fase de fruto chumbinho e início da granação, enquanto a concentração de amônio aumenta no final da granação. A concentração de aminoácidos é superior na antese e no fruto chumbinho.

5. O pico da atividade da enzima redutase do nitrato é obtido aos 25 dias após a adubação nitrogenada.

6. O uso de altas doses de $\mathrm{N}$ não prejudica a concentração de macro e micronutrientes nas folhas.

7. A máxima produtividade do cafeeiro obtem-se com o fornecimento de $400 \mathrm{~kg} \mathrm{ha}^{-1} \mathrm{de}$ nitrogênio. 


\section{REFERÊNCIAS}

AMARAL, J.A.T. Crescimento vegetativo estacional do cafeeiro e suas inter-relações com fontes de nitrogênio, fotoperíodo, fotossíntese e assimolação do nitrogênio. 1991. 139 p. Tese (Doutorado em Fitotecnia) - Universidade Federal de Viçosa, Viçosa, 1991.

AMARAL, J.A.T.; Da MATTA, F.M.; RENA, A.B. Effects of fruiting on the growth of arabica coffee trees as related to carbohydrate and nitrogen status and to nitrate reductase activity.

Brazilian Journal of Plant Physiology, Londrina, v. 13, p. 66-74, 2001.

ANDREWS, R.K.; BLAKELEY, R.L.; ZERNER, B. Urea and urease. Advances in Inorganic Biochemistry, New York, v. 6, p. 245-283, 1984.

ASTOLFI, P.T.; PEDROSO, P.A.C.; CARVALHO, N.M.; SADER, R. Maturação de sementes de café (Coffea arabica L. cv. Mundo Novo). Científica. Joboticabal, v. 9, p. 289-294, 1981.

BAI, C.; REILLY, C.C.; WOOD, B.W. Nickel deficiency disrupts metabolism of ureides, amino acids, and organic acids of young pecan foliage. Plant Physiology, Rockville, v. 140, n. 2, p. 433-443, 2006.

BEEVERS, L.; HAGEMAN, R.H. Nitrate and nitrite reduction. In: STUMPF, P.K.; CONN, E.E. (Ed.). The biochemistry of plants. New York: Academic Press, 1980. p. 115-168.

BIELESKY, R.L.; TURNER, N.A. Separation and estimation of aminoacid in crude plant extracts by thin-layer electrophoresis and chromatography. Analytical Biochemistry, New York, v. 17, p. $278-293,1966$.

BINGHAM, F.T. Boron. In: PAGE, A.L. (Ed.). Methods of soil analysis: chemical and microbiological properties. Madison: American Society of Agronomy, 1982. p. 431-447. (Serie Agronomy, 9).

BRADFORD, M.M. A rapid sensitive method for the quantitation of microgram quantities of protein utilizing the principle of protein-dye-binding. Analytical Biochemistry, New York, v. 72, p. 248-254, 1976.

BREMNER, J.M. Total nitrogen. In: BLACK, C.A. (Ed.). Methods of soil analysis. Madison: American Society of Agronomy, 1965. p. 1149-1178.

BREMNER, J.M.; EDWARDS, H.L. Determination and isotope ratio analysis of differents forms of nitrogen in soils. I. Aparatus and procedures for destillation and determination for ammonium. Soil Science Society of America Proceedings, Madison, v. 29, n. 1, p. 504-507, 1965.

BRETELER, H.; SMITH, A.L. Effect of ammonium nutrition on uptake and metabolism of nitrate in wheat. Netherlands Journal of Agricultural Science, Wageningen, v. 22, p. 73-78, 1974. 
BROUQISSE, R.; MASCLAUX, C.; FELLER, U.; RAYMOND, P. Protein hydrolysis and nitrogen remobilization in plant life and senescence. In: LEA, P.J.; MOROT-GAUDRY, J-F. (Ed.). Plant nitrogen. Berlin: Springer-Verlag, 2001. p. 275-293.

BUCHANAN-WOLLASTON, V.; AINSWORTH, C. Leaf senescence in Brassica napus: Cloning of senescence related genes by subtractive hybridization. Plant Molecular Biology, Dordrecht, v. 33, n. 5, p. 821-834, 1997.

CAMARGO, A.P. Florescimento e frutificação do café arábica nas diferentes regiões cafeeiras do Brasil. Pesquisa Agropecuária Brasileira, Brasília, v. 20, n. 7, p. 831-839, 1985.

CAMARGO, A.P.; CAMARGO, M.B.P. Definição e esquematização das fases fenológicas do cafeeiro arábica nas condições tropicais do Brasil. Bragantia, Campinas, v. 60, n. 1, p. 65-68, 2001 .

CAMARGO, O.A.; MONIZ, A.C.; JORGE, J.A.; VALADARES, J.M.A.S. Métodos de análise química, mineralógica e física de solos do Instituto Agronômico de Campinas. Campinas: Instituto Agronômico, 1986. 94p. (IAC, Boletim Técnico, 106).

CANNEL, M.G.R. Seasonal patterns of growth and development of arabica coffee in Kenya. Part IV. Effects of seasonal differences in rainfall on bean size. Kenya Coffee, Nairobi, v. 36, p. $175-180,1971$.

CARELLI, M.L.C.; FAHL, J.I., MAGALHÃES, A.C. Assimilação de nitrato durante o desenvolvimento reprodutivo de plantas de café. Revista Brasileira de Ciência do Solo, Viçosa, v. 13, p. 59-64, 1989.

. Redução de nitrato em plantas jovens de café cultivadas em diferentes níveis de luz e de nitrogênio. Bragantia, Campinas, v. 49, n. 1, p. 1-9, 1990.

CARR, M.K.V. The water relations and irrigation requirements of coffee. Experimental Agriculture, London, v. 37, n. 1, p. 1-36, 2001.

CARVAJAL, J.F.; ACEVEDO, A.; LOPEZ, C.A. Nutrient uptake by the coffee tree during a yearly cycle. Turrialba, San Jose, v. 19, p. 13-20, 1969.

CARVALHO, C.H.S. de; RENA, A.B.; PEREIRA, A.A.; CORDEIRO, A.T. Relação entre produção, teores de N, P, Ca, Mg, amido e seca de ramos do Catimor (Coffea arabica L.).

Pesquisa Agropecuária Brasileira, Brasília, v. 28, n. 6, p. 665-673, 1993.

CHAVES, J.C.D. Concentração de nutrientes nos frutos e folhas e exportação de nutrientes pela colheita durante um ciclo produtivo do cafeeiro (Coffea arabica L. cv. Cutai). 1982. 131 p. Tese (Mestrado Solos e Nutrição de Plantas) - Escola Superior de Agricultura "Luiz de Queiroz”, Universidade de São Paulo, Piracicaba, 1982. 
COELHO, A.M., FRANÇA, G.E., BAHIA, A.F.C.; GUEDES, G.A.A. Balanço de nitrogênio $(15 \mathrm{~N})$ em um latossolo vermelho-escuro, sob vegetação de cerrado, cultivado com milho. Revista Brasileira de Ciência do Solo, Viçosa, v. 15, p. 187-193, 1991.

COX, G.M.; MUKHERJEE, J.; COLE, G.T.; CASADEYALL, A.; PERFECT, J.R. Urease as a virulence factor in experimental cryptococcosis. Infection Immunity, Bethesda, v. 68, p. 443448, 2000.

DAMATTA, F.M.; AMARAL, J.A.T.; RENA, A.B. Growth periodicity in trees of Coffea arabica L. in relation to nitrogen supply and nitrate reductase activity. Field Crops Research, Amsterdam, v. 60, p. 223-229, 1999.

DECHEN, A.R.; NACHTIGALL, G.R. Micronutrientes. In: FERNANDES, M.S. (Ed). Nutrição mineral de plantas. Viçosa: Sociedade Brasileira de Ciência do Solo, 2006. p. 327-374.

DIXON, N.E.; GAZZOLA, C.; BLAKELEY, R.L.; ZERNER, B. Jack Bean urease (EC 3.5.1.5). A metalloenzyme. A simple biological role for nickel? Journal of the American Chemical Society, Easton, v. 97, n. 14, p. 4131-4133, 1975.

ELLIOTT, W.H. Isolation of glutamine synthetase and glutamotransferase from green peas. Journal of Biological Chemistry, Bethesda, v. 201, p. 661-672, 1953.

EPSTEIN, E.; BLOMM, A. J. Nutrição mineral de plantas: princípios e perspectivas. 2. ed. Londrina: Ed. Planta, 2006. 85 p.

FAHL, J.I.; CARELLI, M.L.C.; VEGA, J.; MAGALHÃES, A.C. Nitrogen and irradiance levels affecting net photosynthesis and growth of young coffee plants (Coffea arabica L.). Journal of Horticultural Science, London, v. 69, p. 161-169, 1994.

FELLER, U.; KEIST, M. Senescence and nitrogen metabolism in annual plants. In: LAMBERS, H.; NEETESON, J.J.; STULEN, I. ( Ed.). Fundamental, ecological and agricultural aspects of nitrogen metabolism in higher plants. Dordrech: Martinus Nijhoff, 1986. p. 219-234.

FENN, L.B.; TAYLOR, R.M.; BURK, C.M. Influenc of plant age on calcium stimulated ammonium absorption by radish and anion. Journal of Plant Nutrition, New York, v. 16, n. 7 , p. $1161-1177,1993$.

FOYER, C.; FERRARIO-MERY, S.; NOCTOR, G. Interactions between carbon and nitrogen metabolism. In: LEA, P.J.; MOROT-GAUDRY, J-F. (Ed.). Plant nitrogen. Berlin: SpringerVerlag, 2001. p. 237-254.

FREITAS, R.B.; ALVES, J.D.; MAGALHÃES, M.M.; GOULART, P.F.P.; NASCIMENTO, M.N.; FRIES, D.D. Adubação do cafeeiro com nitrato de potássio via solo e folha, no outonoinversno e primavera-verão: efeitos na atividade da redutase do nitrato, no crescimento das plantas e na produção. Ciência e Agrotecnólogia, Lavras, v. 31, n. 4, p. 945-952, jul/ago. 2007. 
GERENDÁS, J.; SATTELMACHER, B. Significance of Ni supply for growth, urease activity and the concentrations of urea, amino acids and mineral nutrients of urea-grown plants. Plant and Soil, Dordrecht, v. 190, p. 153-162, 1997.

Influence of Ni supply on growth, urease activity and nitrogen metabolites of Brassica napus grown with $\mathrm{NH}_{4} \mathrm{NO}_{3}$ or urea as $\mathrm{N}$ source. Annals of Botany, Oxford, v. 83, p. 65-71, 1999.

GERENDÁS, J.; POLLACCO, J.; FREYERMUTH, S.K.; SATTELMACHER, B. Co does not replace Ni with respect to urease activity in zucchini (Cucurbita pepo convar. giromontiina) and soybean (Glycine max). Plant and Soil, Dordrecht, v. 203, p. 127-135, 1998.

GONÇALVES, G.C. Cultivo em campo de Coffea arábica L. cv. Obatã a pleno sol x sombreamento parcial: avaliações bioquímicas, fisiológicas e nutricionais. 2007. 116 p. Tese (Doutorado em Fisiologia e Bioquímica de Plantas) - Escola Superior de Agricultura "Luiz de Queiroz", Universidade de São Paulo, Piracicaba, 2007.

GUIMARÃES, P.T.G.; GARCIA, A.W.R.; ALVAREZ V., V.H.; PREZOTTI, L.C.; VIANA, A.S.; MIGUEL, A.E.; MALAVOLTA, E.; CORREA, J.B., LOPES, A.S.; NOGUEIRA, F.D.; MONTEIRO, A.V.C. Cafeeiro. In: RIBEIRO, A.C.; GUIMARÃES, P.T.G.; ALVAREZ V., V.H. (Ed.). Recomendações para o uso de corretivos e fertilizantes em Minas Gerais: $5^{\text {a }}$ aproximação. Viçosa: Comissão de Fertilidade do Solo do Estado de Minas Gerais, 1999. p. 289302.

HEBER, U.; KIRK, M.R.; GIMMLER, H.; SCHAFER, G. Uptake and reduction of glycerate by isolated chloroplasts. Planta, Berlin, v. 120, n. 1, p. 31-46, 1974.

HIRAYAMA, C.; SUGIMURA, M.; SAITO, H.; NAKAMURA, M. Purification and properties of urease from leaf of mulberry Morus Alba. Phytochemistry, Oxford, v. 53, p. 325-330, 2002.

HOGAN, M.E.; SWIFT, I.E.; DONE, J. Urease assay and ammonia release from leaf tissue. Phytochemistry, Oxford, v. 22, p. 663-665, 1983.

HUCKLESBY, D.P.; BLANKE, M.M. Limitation of nitrogen assimilation in plants. IV. Effect of defruiting on nitrate assimilation, transpiration and photosynthesis in tomato leaf.

Gartenbauwissenschaft, v. 57, p. 53-56, 1992.

IRELAND, R.J.; LEA, P.J. The enzymes of glutamine, glutamate, asparagine and aspirate metabolism. In: SINGH, B.K. (Ed.). Plant amino acids: biochemistry and biotechnology. New York: 1999. p. 49-109.

JACKSON, M.L. Soil chemical analysis. New Jersey: Prentice Hall, 1958. 498 p.

JOHNSON, C.M.; ULRICH, A. Analytical methods for use in plants analyses. Los Angeles: University of California, v.766, p. 32-33, 1959. 
JONES JUNIOR, J.B. Distribution IF 15 elements in com leaves. Communications in Soil Science and Plant Analysis, New York, v. 1, n. 1, p 27-34, 1970.

KAISER, W.M.; HUBER, S.C. Post-translational regulation of nitrate reductase: mechanism, physiological relevance and environmental triggers. Journal of Experimental Botany, Oxford, v. 52, p. 1981-1989, 2001.

KAISER, W.M.; WEINER, H.; KANDLBINDER, A. TSAI, C.; ROCKEL, M.S.; PLANCHET, E. Modulation of nitrate reductase: some new insights, an unusual case and a potentially important side reaction. Journal of Experimental Botany. Inorganic Nitrogen Assimilation, v. 53, n. 370, p. 875-882, Apr. 2002. Special issue.

KERBAUY, G.B. Nutrição mineral. In: Fisiologia vegetal. Rio de Janeiro: Guanabara Koogan, 2004. cap. 2, p. 40-75.

KROGMEIER, M.J.; MCCARTY, G.W.; BREMNER, J.M. Phytotoxicity of foliar-applied urea. Proceedings of the National Academy of Sciences of the USA, Washington, v. 86, p. 8189, 1989.

LANCIEN, M.; GADAL, P.: HODGES, M. Enzyme redundancy and the importance of 2oxoglutarate in higher plant ammonium assimilation. Plant Physiology, Rockville, v. 123, p.817-824, 2000.

LARCHER, W. Ecofisiologia vegetal. São Carlos: Rima Editora, 2004. 531 p.

LAVIOLA, B.G.; MARTINEZ, H.E.P.; SOUZA, R.B. de; ALVAREZ V., V.H. Dinâmica de cálcio e magnésio em folhas e frutos de cafeeiro arábico em três níveis de adubação. Revista Brasileira de Ciência do Solo, Viçosa, v. 31, p. 319-329, 2007 a.

LAVIOLA, B.G.; MARTINEZ, H.E.P.; SALOMÃO, L.C.C.; CRUZ, C.D.; MENDONÇA, S.M.; NETO, A.P. Partição de fotoassimilados entre folhas e frutos de cafeeiro cultivado em duas altitudes. Pesquisa Agropecuária Brasileira, Brasília, v. 42, n. 11, p. 1521-1530, 2007b.

LAVIOLA, B.G.; MARTINEZ, H.E.P.; SALOMÃO, L.C.C.; CRUZ, C.D.; MENDONÇA, S.M.; ROSADO, L.D.S. Acúmulo em frutos e variação na concentração foliar de NPK em cafeeiro cultivado em quatro altitudes. Bioscience Journal, Uberlândia, v. 24, n. 1, p. 19-31, jan./mar. 2008 .

LAVIOLA, B.G.; MARTINEZ, H.E.P.; SALOMÃO, L.C.C.; CRUZ, C.D.; MENDONÇA, S.M.; MENDONÇA, S.M.; ROSADO, L.D.S. Acúmulo de nutrientes em frutos de cafeeiro em duas altitudes de cultivo: micronutrientes. Revista Brasileira de Ciência do Solo, Viçosa, v. 31, p. 1439-1449, 2007.

LAWLOR, D.W. Photosynthesis, productivity and environment. Journal of Experimental Botany, Oxford, v. 46, p. 1449-1461, 1995. 
Carbon and nitrogen assimilation in relation to yield: mechanisms are the key to understanding production systems. Journal of Experimental Botany, Oxford, v. 53, n. 370, p. 773-787, 2002.

LAWLOR, D.W.; KONTTURI, M.; YOUNG, A.T. Photosynthesis by flag leaves of wheat in relation to protein, ribulose bisphosphate carboxylase activity and nitrogen supply. Journal of Experimental Botany, Oxford, v. 40, p. 43-52, 1989.

LAWLOR, D.W.; LEMAIRE, G.; GASTAL, F. Nitrogen, plant growth and crop yield. In: LEA, P.J.; MOROT-GAUDRY, J.F. (Ed.). Plant nitrogen. Berlin: Springer Verlag, 2001. p. 343-367.

LAWLOR, D.W.; BOYLE, F.A.; KEYS, A.J.; KENDALL, A.C.; YOUNG, A.T. Nitrate nutrition and temperature effects on wheat: a synthesis of plant growth and nitrogen uptake in relation to metabolic and physiological processes. Journal of Experimental Botany, Oxford, v. 39, p. 329343, 1988.

LEA, P.J.; IRELAND, R.J. Nitrogen metabolism in higher plants. In: SINGH, B.K. (Ed.). Plant amino acids: biochemistry and biotechnology. New York: Marcel Dekker, 1999. p. 1-47.

LEA, P.J.; BLACKWELL, R.D.; JOY, K.W. Ammonia assimilation in higher plants. In: MENGEL, K.; PILBEAM, D.J. (Ed.). Nitrogen metabolism of plants. Oxford: Clarendon, 1992. p. 153. (Proceedings of the Phytochemical Society of Europe, 33).

LEA, P.L.; MOROT-GAUDRY, J.F. (Ed.). Plant nitrogen. Berlin; London: Springer, 2001. $407 \mathrm{p}$.

LEE, D.W.; BRAMMEIER, S.; SMITH, A.P. The selective advantages of anthocyanins in developing leaves of mango and cacao. Biotropica, Washington, v. 19, n. 1, p. 40-49, 1987.

LEMAIRE, G.; KHAITY, M; ONILLON, B.; ALLIRAND, J.M.; CHARTIER, M.; GOSSE, G. Dynamics of accumulation and partitioning of $\mathrm{N}$ in leaves, stems and roots of Lucerne (Medicago sativa) in a dense canopy. Annals of Botany, Oxford, v. 70, p. 429-435, 1992.

LIMA, E.P. Graus-dia, temperatura base e coeficientes de cultura para cafeeiros arábica em fase de implantação. 2006. 116 p. Tese (Doutorado em Engenharia Agrícola) - Universidade Federal de Lavras, Lavras, 2006.

LONERAGAN, J.F. Distribution and movement of copper in plants. In: LONERAGAN, J.F.; ROBSON, A.D.; GRAHAM, R.D. (Ed.). Copper in soils and plants. Sydney: Academic Press, 1981. p. 165-188.

LOUIS, P.L. Urea statistics 1991. 1992. 12 p. (IFA. Publication, A/92/73).

LU, C.; ZHANG, J. Photosynthetic $\mathrm{CO}_{2}$ assimilation, chlorophyll fluorescence and photoinibition as by nitrogen deficiency in maize plants. Plant Science, Amsterdam, v. 151, p. 135-143, 2000. 
MACHLER, F.; OBERSON, A.; GRUB, A.; NOSBERGER, J. Regulation of photosynthesis in nitrogen-deficient wheat seedlings. Plant Physiology, Rockville, v. 87, p. 46-49, 1998.

MALAVOLTA, E. Nutrição, adubação e calagem para o cafeeiro. In: RENA, A.B.; MALAVOLTA E.; ROCHA, M.; YAMADA, T. (Ed.). Cultura do cafeeiro: fatores que afetam a produtividade. Piracicaba: POTAFOS, 1986. p. 165-274.

. Manual de nutrição mineral de plantas. Piracicaba: Ceres, 2006. 638 p.

MALAVOLTA, E.; VITTI, G.C.; OLIVEIRA, S.A. Avaliação do estado nutricional das plantas: princípios e aplicações. 2. ed. Piracicaba: Associação Brasileira para Pesquisa do Fosfato, 1997. $238 \mathrm{p}$.

MARENCO, R.A.; LOPES, N.F. Fisiologia vegetal: fotossíntese, respiração, relações hídricas e nutrição mineral. Viçosa: UFV, 2005. 451 p.

MARSCHNER, H. Mineral nutrition of higher plants. $2^{\text {nd }}$ ed. London: Academic Press, 1995. $889 \mathrm{p}$.

MARTINEZ, H.E.P.; MENEZES, J.F.S.; SOUZA, R.B.; ALVAREZ V., V.H.; GUIMARÃES, P.T.G. Faixas críticas de concentrações de nutrientes e avaliação do estado nutricional de cafeeiros em quatro regiões em Minas Gerais. Pesquisa Agropecuária Brasileira, Brasília, v. 38, n. 6, p. 703-713, 2003.

MATSON, P.A.; BILLOW, C.; HALL, S. Fertilization practices and soil variations control nitrogen oxide emissions from tropical sugar cane. Journal of Geophysical Research, Washington, v. 101, p. 18533-18545, 1996.

MATSON, P.A.; NAYLOR, R.; ORTIZ-MONASTERIO, I. Integration of enviromental, agronomic and economic aspects of fertilizer management. Science, Washington, v. 280, p. 1-8, 1998.

McCULLOUGH, H. The determination of ammonia in whole blood by a direct colorimetric method. Clinica Chimica Acta, Amsterdam, v. 17, n. 2, p. 297-304, 1967.

MOBLEY, H.L.T., ISLAND, M.D., HAUSINGER, R.P. Molecular biology of microbial ureases. Microbiological Reviews, Washington, v. 59, n. 3, p. 451-480, 1995.

MORAES, F.R.P.de. Meio ambiente e práticas culturais. In: KRUG, C.A.; MALAVOLTA, E.; MORARES, R.P., DIAS; CARVALHO, A.; FRANCO, L.C.M.C.; BERGAMIN, J.; ABRAHÃO, J.; SOUZA, A.R.O.F.de; FAVA, J.F.M. Cultura e adubação do cafeeiro. São Paulo: Instituto Brasileiro de Potassa - Experimentações e Pesquisa, 1963. cap. 5, p.75-126.

MORAN, R. Formulae for determination of chlorophyllous pigments extracted with N,N,dimethylformamide. Plant Physiology, Rockville, v. 69, p. 1376-1381, 1982. 
MOROT-GAUDRY, J.F.; JOB, D.; LEA, P.J. Amino acid metabolism. In: LEA, P.J.; MOROTGAUDRY, J-F. (Ed.). Plant nitrogen. Berlin: Springer-Verlag, 2001. p. 275-293.

MUÑOZ, A., RASO, M.J., PINEDA, M., PIEDRAS, P. Degradation of ureidoglycolate in French bean (Phaseolus vulgaris) is catalysed by a ubiquitous ureidoglycolate urea-lyase. Planta, Berlin, v. 224, n. 1, p. 175-184, 2006.

NAZARENO, R.B.; OLIVEIRA, C.A.S.; SANZONOWICZ, C.; SAMPAIO, J.B.R.; SILVA, J.C.P.; GUERRA, A.F. Crescimento inicial do cafeeiro Rubi em resposta a doses de nitrogênio, fósforo e potássio e a regimes hídricos. Pesquisa Agropecuária Brasileira, Brasília, v. 38, p. 903-910, 2003.

NETTO, J. Atividade das enzimas redutase do nitrato e glutaminasintetase em cafeeiro arábica. 2005. 60 p. Dissertação (Mestrado em Fitotecnia) - Escola Superior de Agricultura "Luiz de Queiroz", Universidade de São Paulo, Piracicaba, 2007.

OAKS, A. Nitrogen assimilation in roots: a re-evaluation. BioScience, Washington, v. 42, p. 103$111,1991$.

Primary nitrogen assimilation in higher plants and its regulation. Canadian Journal of Botany, Otawa, v. 72, p. 739-750, 1994.

OAKS, A.; HIREL, B. Nitrogen metabolism in roots. Annual Review of Plant Physiology, Rockville, v. 36, p. 345-365, 1985.

OAKS, A.; WALLACE, W.; STEVENS, D. Synthesis and turnover of nitrate reductase in corn roots. Plant Physiology, Rockville, v. 50, p. 649-654, 1972.

OLIVEIRA, I.C.; CORUZZI, G.M. Carbon and amino acids reciprocally modulate the expression of glutamine synthetase in Arabidopsis. Plant Physiology, Rockville, v. 121, n. 1, p. 301-309, 1999.

PANEK, J.A.; MATSON, P.A.; ORTIZ-MONASTERIO, I. BOOKS, P. Distinguishing nitrification and desnitrification sources of $\mathrm{N}_{2} \mathrm{O}$ in a Mexican wheat system using ${ }^{15} \mathrm{~N}$.

Ecological Aplication, Washington, v.10, p. 506-514, 2000.

PEOPLES, M.B.; HERRIDGEE, D.F.; LADHA, J.K. Biological nitrogen fixation: An efficient source of nitrogen for sustainable agricultural production? Plant and Soil, Dordrecht, v. 174, p. 3-28, 1995.

POLLACCO, J.C., HOLLAND, M.A. Roles of urease in plant cells. International Review of Cytology, New York, v. 145, p. 65-103, 1993.

QUEIROZ, C.G.A.; RENA, A.B.; CORDEIRO, A.T.; ALVES, J.D. Ritmo diurno na atividade de redutase do nitrato em folhas e raízes de Coffea arabica L. Pesquisa Agropecuária Brasileira, Brasília, v. 28, p. 787-795, 1993. 
RADIN, J.W. Distribution and development of nitrate reductase activity in germinating cotton seedlings. Annual Review of Plant Physiology, Stanford, v. 53, p. 458-463, 1974.

RAIJ, B. van; ANDRADE, J.C.; CANTARELLA, H.; QUAGGIO, J.A. Análise química para avaliação da fertilidade de solos tropicais. Campinas: Instituto Agronômico, 2001. 285 p.

RAIJ, B.van; CANTARELLA, H.; QUAGGIO, J.A.; FURLANI, A. M. C. (Ed.).

Recomendações de adubação e calagem para o Estado de São Paulo. 2. ed. Campinas: IAC, 1996. 285 p. (IAC. Boletim Técnico, 100)

RAMÍREZ, F.; BERTSCH, F.; MORA, L. Consumo de nutrimentos por los frutos y bandolas de cafe Caturra durante um ciclo de desarrollo y maduracion en Aquiares, Turrialba, Costa Rica. Agronomia Costarricense, San Jose, v. 26, n. 1, p. 33-42, 2002.

RAVEN, J.A. Short-and long-distance transporto f boric acid in plants. New Phytologist, London, v. 84, p. 231-249, 1980.

REIS, A.R. Metabolism do nitrogênio e estado nutricional do cafeeiro (Coffea arabica). 2007. 79 p. Dissertação (Mestrado em Fitotecnia) - Escola Superior de Agricultura "Luiz de Queiroz", Universidade de São Paulo, Piracicaba, 2007.

REIS, A.R.; FAVARIN, J.L.; GALLO, L.A.; MALAVOLTA, E.; MORAES, M.F.; LAVRES JUNIOR, J. Nitrate reductase and glutamine synthetase activity in coffee leaves during fruit development. Revista Brasileira de Ciência dos Solos, Viçosa, v. 33, p. 315-324, 2009.

RENA, A.B.; FAVARO, J.R.A. Nutrição do cafeeiro via folha. In: ZAMBOLIM, L. (Ed.). Café: produtividade, qualidade e sustentabilidade. Viçosa: UFV, Departamento de Fitopatologia, 2000. p. 149-208.

RENA, A. B.; MAESTRI, M. Fisiologia do cafeeiro. Informe Agropecuário, Belo Horizonte, v. 11, n. 126, p. $26-40,1985$

RENA, A.B.; BARROS, R.S.; MAESTRI, M. Desenvolvimento reprodutivo do cafeeiro. In: ZAMBOLIM L. Tecnologias de produção de café com qualidade. Viçosa: UFV, Departamento de Fitopatologia, 2001. p. 101-128.

RIBEIRO, A.C.; GUIMARÃES, P.T.G.; ALVAREZ V., V.H. (Ed.). Recomendação para o uso de corretivos e fertilizantes em Minas Gerais: 5. Aproximação. Viçosa: Comissão de Fertilidade do Solo do Estado de Minas Gerais, 1999. 359 p.

SCHEIBLE, W-R.; GONZÁLES-FONTES, A.; LAUERER, M. et al. Nitrate acts as a signal to introduce organic acid metabolism and repress starch metabolism in tobacco. The Plant Cell, Baltimore, v. 9, p. 783-798, 1997.

SILVA E SOUZA, V.H. da; MAESTRI, M.; BRAGA, J.; CHAVES, J.R.P. Variações no teor de alguns elementos minerais nas folhas e frutos de café (Coffea arabica L. var. "Mundo Novo"). Revista Ceres. Viçosa, v. 22, n. 123, p. 310-331, 1975. 
SILVASANKAR, S; OAKS, A. Nitrate assimilation in higher plants - the effect of metabolites and light. Plant Physiology Biochem v. 34, p. 609-620, 1996.

SIQUEIRA, J.O.; RANCO, A.A. Biotecnologia do solo: fundamentos e perspectivas. Brasília: MEC, ABEAS; Lavras: ESAL, FAEPE, 1988. 250 p.

SOARES, A.R.; MOURA, B.R. DE; RODRIGUES, S.B.S.; VICENTE, M.R.; MANTOVANI, E.C. Utilização de diferentes fontes de nitrogenio e potássio na produtividade de cafeeiros irrigados e fertirrigados. In: SIMPÓSIO DE PESQUISA DOS CAFÉS DO BRASIL, 4., 2005, Londrina. Anais... Brasília: Embrapa - Café, 2005.

SOLOMONSON, L.P.; BRAKER, M.J. Assimilatory nitrate reductase: functional properties and regulation. Annual Review of Plant Physiology and Plant Molecular Biology, Palo Alto, v. 41, p. 225-253, 1990.

STITT, M. Frutose-2, 6-biphosphate and carbohydrate metabolism. Plant Physiology, Rockville, v. 84 , p. 202-204, 1987.

TAIZ, L.; ZEIGER, E. Fisiologia vegetal. 3. ed. Porto Alegre: Artmed, 2004. 719 p.

TALEISNIK, E.; BRICEÑO, J.A.; CARVAJAL, J.F. Variación estacional de la reductasa de nitrato em el cafeto. Turrialba, San Jose, v. 30, p. 330-337, 1980.

TEDESCO, M.J.; GIANELLO, C. Conjunto modulado em vidro para destilação a vapor de amônia pelo método Kjeldahl. Revista Brasileira de Ciência do Solo, Viçosa, v. 3, p. 61-63. 1979.

TEDESCO, M.J.; VOLKWEISS, S.J.; BOHNEN, H. Análises de solo, plantas e outros materiais. Porto Alegre: Universidade Federal do Rio Grande do Sul, 1985. 95 p. (Boletim Técnico, 5).

TEMPLE, S.J.; VANCE, C.P.; GANTT, J.S. Glutamate synthase and nitrogen assimilation. Trends in Plant Science, Kidlington, v. 3, p. 51-56, 1998.

THOMPSON, J.F. Arginine synthesis, proline synthesis, and related processes. The Biochemistry of Plants, New York, v. 5, p. 375-402, 1980.

TODD, C.D.; POLLACCO, J.C. Soybean cultivars 'Williams 82' and 'Maple Arrow' produce both urea and ammonia during ureide degradation. Journal of Experimental Botany, Oxford, v. 55, n. 398, p. $867-877,2004$

VANCE, C.P.; UHDE-STONE, C.; ALLEN, D.L. Phosphorus acquisition and use: critical adaptations by plants for securing a nonrenewable resource. New Phytologist, London, v. 157, p. 423-447, 2003.

VITTI, G.C. Avaliação e interpretação do enxofre no solo e na planta. Jaboticabal: FUNEP, 1988. $37 \mathrm{p}$. 
VITTI, G.C.; LIMA, E.; CICARONE, F. Cálcio, magnésio e enxofre. In: FERNANDES, M.S. (Ed.). Nutrição mineral de plantas. Viçosa: Sociedade Brasileira de Ciência do Solo, 2006. p. 299-325.

WALLSGROVE, R.M.; TURNER, J.C.; HALL, N.P.; KENDALL, A.C.; BRIGHT, S.W.J. Barley mutants lacking chloroplast glutamine synthetase-biochemical and genetic analysis. Plant Physiology, Rockville, v. 83, p.155-158, 1987.

WEITZ, A.M.; LINDER, E.; FROLKING, S.; CRILL, P.M.; KELLER, M. $\mathrm{N}_{2} \mathrm{O}$ emissions from humid tropical agricultural soils: effects of soil moisture, texture and nitrogen availability. Soil Biology and Biochemistry, Oxford, v. 33, p. 1077-1093, 2001.

WILLSON, K.C. Mineral nutrition and fertilizer needs. In: CLIFFORD, M.N.; WILLSON, K.C. (Ed.). Coffee: botany, biochemistry and production of beans and beverage. London: Croom Helm, 1985. p. 135-156. 